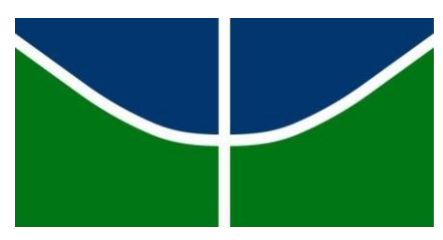

UNIVERSIDADE DE BRASÍLIA FACULDADE DE COMUNICAÇÃO PROGRAMA DE PÓS-GRADUAÇÃO

CARLA ALESSANDRA TIMM

UMA ANÁLISE SOBRE A POLÍTICA DE COMUNICAÇÃO DA EMBRAPA APLICADA À TRANSFERÊNCIA DE TECNOLOGIA PARA A AGRICULTURA FAMILIAR 
UMA ANÁLISE SOBRE A POLÍTICA DE COMUNICAÇÃO DA EMBRAPA APLICADA À TRANSFERÊNCIA DE TECNOLOGIA PARA A AGRICULTURA FAMILIAR

Dissertação apresentada ao programa de Pósgraduação em Comunicação da Faculdade de Comunicação, Universidade de Brasília, como requisito parcial para a obtenção do grau de Mestre em Comunicação, na linha de pesquisa Políticas de Comunicação e Cultura.

Orientador: Prof. Dr. Carlos Eduardo Machado da Costa Esch 


\title{
UMA ANÁLISE SOBRE A POLÍTICA DE COMUNICAÇÃO DA EMBRAPA APLICADA À TRANSFERÊNCIA DE TECNOLOGIA PARA A AGRICULTURA FAMILIAR
}

\begin{abstract}
Dissertação apresentada ao programa de Pósgraduação em Comunicação da Faculdade de Comunicação, Universidade de Brasília, como requisito parcial para a obtenção do grau de Mestre em Comunicação, na linha de pesquisa Políticas de Comunicação e Cultura, em 05 de agosto de 2015.
\end{abstract}

BANCA EXAMINADORA:

Prof. Dr. Carlos Eduardo Machado da Costa Esch (Presidente)

Universidade de Brasília

Prof ${ }^{a}$. Dra ${ }^{\mathrm{a}}$ Nelia R. Del Bianco (Membro)

Universidade de Brasília

Prof $^{a}$. Dr ${ }^{\mathrm{a}}$. Maria da Graça Miranda de França Monteiro (Membro Externo)

Embrapa

Prof $^{\mathrm{a}}$. Dra ${ }^{\mathrm{a}}$. Janara Kalline Leal Lopes de Sousa (Suplente)

Universidade de Brasília 
"Você poderia me dizer, por favor, por qual caminho devo seguir agora?", perguntou ela. Isso depende muito do lugar para onde você quer ir", respondeu o gato.

Lewis Carrol, Alice no País das Maravilhas 


\section{AGRADECIMENTOS}

Esta dissertação tornou-se possível graças a muitas pessoas, e o presente registro de agradecimento não será suficiente para expressar a importância que todas elas tiveram na viabilização deste projeto.

Ao meu orientador, professor Carlos Eduardo, pela orientação, dedicação, estímulo e, sobretudo, pela competência com que me ajudou a conduzir a elaboração deste trabalho.

Ao Marcelo, meu amor, companheiro e melhor amigo, pela compreensão e apoio nas horas de inspiração ou nas horas de falta dela.

À minha mãe, eterna incentivadora.

Às minhas conselheiras e amigas, Juliana e Fada Madrinha, pela disponibilidade, carinho e amizade com que muitas vezes me ajudaram a "clarear as ideias".

Aos amigos que fiz na UnB, especialmente à Aline e à Luma, que acabaram se tornando grandes companheiras nessa jornada chamada mestrado.

Aos colegas e amigos Sérgio Bender e Orebio, pela parceria nas excursões pelo interior do país e também pela amizade que sempre me dedicaram.

Aos entrevistados, agricultores familiares, extensionistas e colegas da Embrapa, pela disponibilidade, gentileza e paciência.

Aos amigos que entenderam e respeitaram os motivos pelos quais, muitas vezes, deixei-os de lado.

À chefia da Embrapa Hortaliças, pela compreensão e incentivo para que eu pudesse fazer o mestrado da melhor forma possível.

À professora Nelia e a Maria da Graça, pelas valiosas colaborações para a construção deste trabalho.

À Embrapa, pela oportunidade de crescimento pessoal e profissional.

A todos, minha sincera gratidão. 


\section{RESUMO}

Este trabalho investiga a política adotada pela Empresa Brasileira de Pesquisa Agropecuária (Embrapa) no que se refere à comunicação para a transferência de tecnologia voltada para a agricultura familiar, um segmento que passou a ocupar um importante espaço na agenda governamental, e que responde hoje no Brasil por sete em cada 10 empregos no campo e por cerca de $40 \%$ da produção agrícola. Para verificar o que é proposto pela instituição e o que os atores que fazem parte desse processo pensam e como se manifestam com relação a esse tema, foram realizadas uma análise documental e uma pesquisa de campo, em que foram entrevistados gestores da Embrapa, extensionistas rurais e agricultores familiares, nos estados do Rio Grande do Sul e Goiás. Como abordagem teórico-metodológica, foi utilizado o método dialético, o que permitiu uma interpretação total e dinâmica da realidade estudada. São abordados conceitos que dialogam com o tema da pesquisa, com destaque para o da comunicação para o desenvolvimento, tendo em vista seu papel estratégico no processo de mudança social, atuando como facilitadora de trocas e aproximações entre os atores. Ao longo da investigação foi identificado que existem movimentos da empresa no sentido de se comunicar com a agricultura familiar, mas não há um consenso institucional sobre o processo, os conceitos e as possibilidades de ação com o segmento, dificultando o estabelecimento de uma política articulada de atuação.

Palavras-chave: política de comunicação; transferência de tecnologia; agricultura familiar; comunicação para o desenvolvimento; comunicação para transferência de tecnologia. 


\begin{abstract}
This work is a research about the policy implemented by the Brazilian Agricultural Research Corporation (Embrapa) concerning communication to technology transfer used in family farm, a field that has moved to a central focus in the governmental agenda, and that today, in Brazil, is responsible for seven out of each ten employment opportunities in rural communities and by around $40 \%$ of the agricultural production. In order to examine the items proposed by the Corporation and the considerations and roles that the actors in this process perform on this subject, a documental analysis and a field research were carried out, in which Embrapa managers, rural extension workers and family farmers, in the states of Rio Grande do Sul and Goiás, were interviewed. Under a theoretical and methodological approach, the dialectical method was used, which allowed a complete and dynamic interpretation of the studied reality. Concepts dealing with the research subject, stressing the one of communication for the development, considering the key role it performs in the process of social change, supportting and making easier the exchanges and approximation between the actors, are analysed. During the investigation it was identified that there are some activities in the Brazilian research Corporation so that to set a communication with the family farming sector, although there is not an institutional agreement about the process, concepts, and possibilities of actions with this segment, making difficult the implementation of an expressive and voiced policy to act in this process.
\end{abstract}

Key-words: communication policy; technology transfer; family farm; communication for development; communication for technology transfer. 


\section{LISTA DE FIGURAS, TABELAS E GRÁFICOS}

Figura 1: Locais das entrevistas............................................................... 37

Tabela 1: Categorias de Análise.................................................................... 45

Gráfico 1: Desenvolvimento de tecnologias para a agricultura familiar.................... 69

Gráfico 2: Recebimento e de informações sobre a Embrapa e/ou suas tecnologias..... 76

Gráfico 3: Conhecimento sobre os programas de TV e rádio da Embrapa.................. 77 


\section{LISTA DE SIGLAS E ABREVIATURAS}

Anater - Agência Nacional de Assistência Técnica e Extensão Rural Ater - Assistência Técnica e Extensão Rural

Conab - Companhia Nacional de Abastecimento

Contag - Confederação Nacional dos Trabalhadores da Agricultura

DTT - Departamento de Transferência de Tecnologia

Emater - Empresa de Assistência Técnica e Extensão Rural

Embrapa - Empresa Brasileira de Pesquisa Agropecuária

FAO - Organização das Nações Unidas para Alimentação e Agricultura

Fetraf - Federação dos Trabalhadores na Agricultura Familiar

GO - Goiás

IDH - Índice de Desenvolvimento Humano

IBGE - Instituto Brasileiro de Geografia e Estatística

Incra - Instituto Nacional de Colonização e Reforma Agrária

MAPA - Ministério da Agricultura Pecuária e Abastecimento

MDA - Ministério do Desenvolvimento Agrário

MIT - Instituto Tecnológico de Massachusetts

ONU - Organização das Nações Unidas

PCMF - Programa de Combate à Miséria e à Fome

PDE - Plano Diretor da Embrapa

PDU - Plano Diretor da Unidade

PNB - Produto Nacional Bruto

PNUD - Programa das Nações Unidas para o Desenvolvimento

Procera - Programa de Crédito para a Reforma Agrária

Pronaf - Programa Nacional de Fortalecimento da Agricultura Familiar

RS - Rio Grande do Sul

Secom - Secretaria de Comunicação

Sibrater - Sistema Brasileiro de Assistência Técnica e Extensão Rural

SNPA - Sistema Nacional de Pesquisa Agropecuária

TT - Transferência de Tecnologia

UD - Unidade

Usaid - Agência dos Estados Unidos da América para o Desenvolvimento Internacional 


\section{SUMÁRIO}

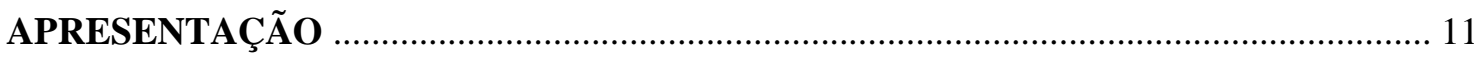

1 AGRICULTURA FAMILIAR E EMBRAPA: O CONTEXTO.................................... 13

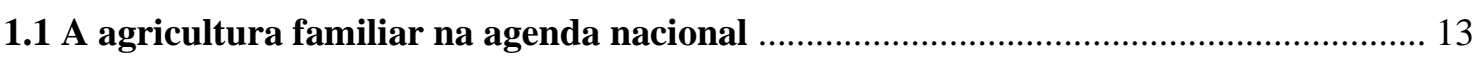

1.1.1 Agricultura familiar: um novo retrato e um marco legal_.............................................. 15

1.2 Embrapa: uma história e um contexto …………....................................................... 17

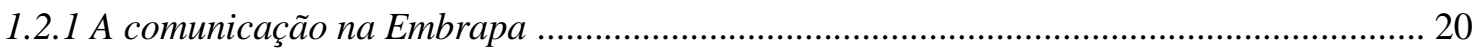

1.2.2 A imagem da Embrapa diagnosticada a partir de uma pesquisa ................................... 21

1.3 Comunicação, transferência de tecnologia e agricultura familiar para a

Embrapa: um olhar a partir dos documentos institucionais ..................................... 23

1.3.1 A Política de Comunicação da Embrapa ........................................................................... 24

1.3.2 Marco Referencial de Transferência de Tecnologia, Intercâmbio e Construção

Coletiva do Conhecimento................................................................................................... 27

1.3.3 Plano Diretor da Embrapa (PDE) ................................................................................ 31

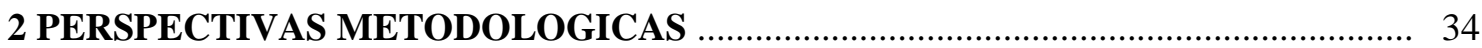

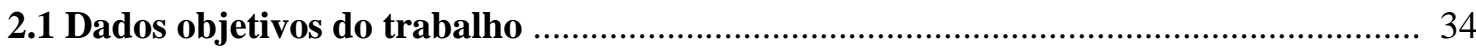

2.2 Abordagem teórico-metodológica, método de análise e técnicas de coleta de dados... 38

2.2.1 O método dialético como abordagem teórico-metodológica ........................................... 38

2.2.2 A Análise de conteúdo e a análise documental ................................................................. 39

2.2.3 O uso da entrevista em profundidade como técnica de coleta de dados............................ 40

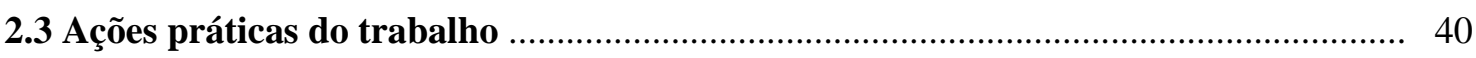

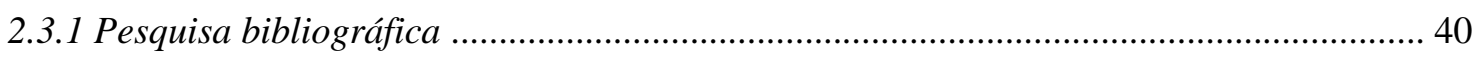

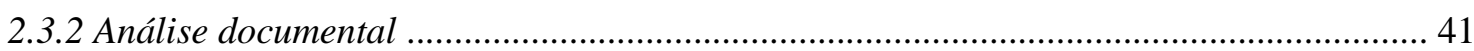

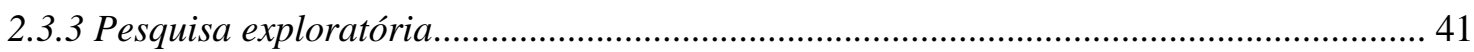

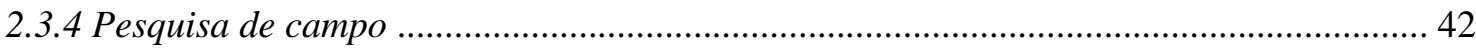

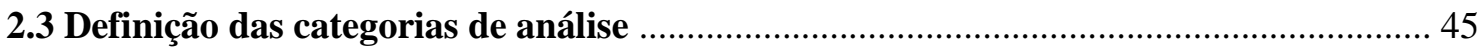

3 A COMUNICAÇÃO PARA O DESENVOLVIMENTO COMO PONTO DE

REFLEXÃO E OUTRAS PERSPECTIVAS CONCEITUAIS ................................... 47

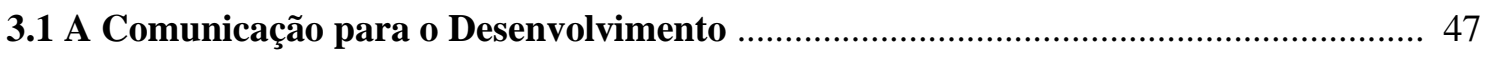

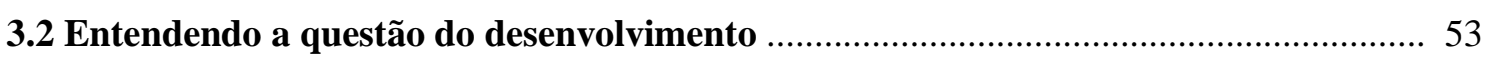

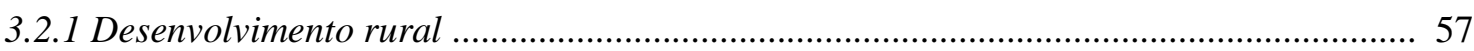

3.3 Política públicas de comunicação no contexto do desenvolvimento rural no

Brasil.

3.4. Uma noção básica da política aplicada ao contexto da ação pública ............................. 63

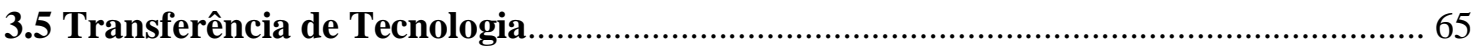

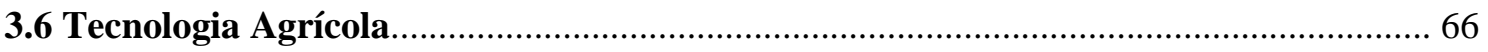


3.7 Informação Tecnológica

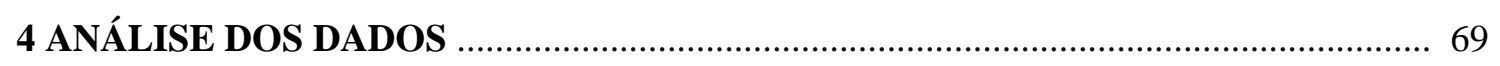

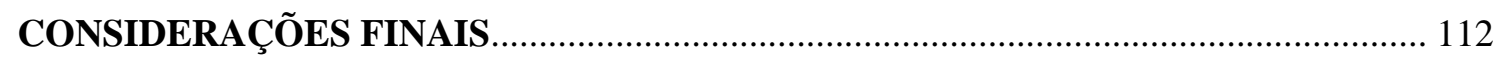

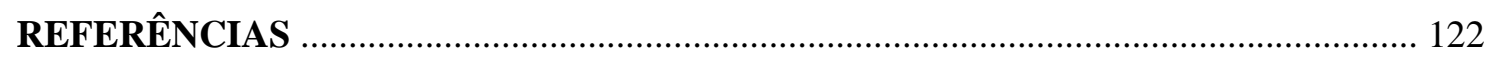

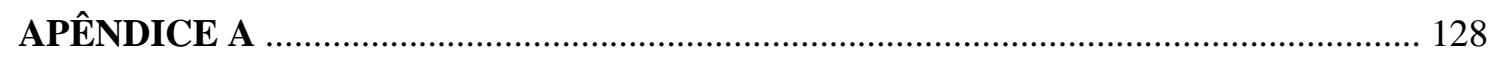

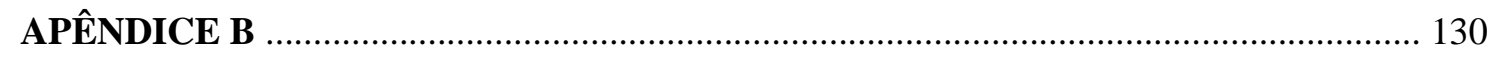

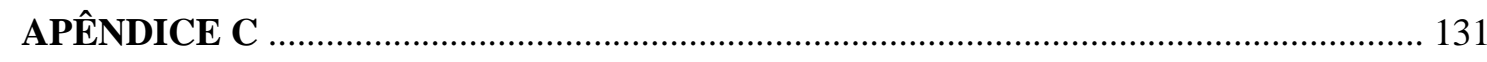

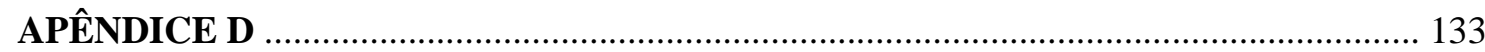




\section{APRESENTAÇÃO}

A agricultura familiar atualmente ocupa um espaço de destaque na agenda governamental e é de grande importância para o país por sua expressiva contribuição na produção de alimentos, mas ainda é um segmento que necessita e demanda acesso às tecnologias para seu desenvolvimento econômico e inclusão social. Assim, a Empresa Brasileira de Pesquisa Agropecuária (Embrapa), por ser uma empresa pública que gera tecnologias capazes de promover mudanças sociais e econômicas em segmentos rurais, precisa estabelecer uma relação e uma comunicação efetiva com esses agricultores, que comprovadamente fazem parte de seu público de atuação.

E é no universo onde os atores, Embrapa e agricultores familiares, se relacionam que o objeto de estudo deste trabalho se constrói, especificamente no que se refere à política de comunicação da Embrapa aplicada à transferência de tecnologia para a agricultura familiar. Diante de tais delimitações, as duas ideias fundamentais que impulsionaram este trabalho foram: a) verificar o que oficialmente a instituição propõe e o que, de fato, faz na prática com relação ao uso da comunicação com o propósito de disponibilizar tecnologias para um segmento produtivo específico da agricultura; e b) o que os agricultores familiares e os demais atores envolvidos no processo (extensionistas rurais e gestores da própria Embrapa) pensam e como se manifestam com relação à forma pela qual a Embrapa disponibiliza, ou não, as novas tecnologias para o setor.

O trabalho está estruturado em quatro capítulos. O primeiro contextualiza o universo e atores da pesquisa, apresentando um histórico, os principais conceitos e informações acerca da agricultura familiar no Brasil, e estabelece um panorama sobre a Embrapa, com enfoque na comunicação realizada pela empresa e em dados que mostram a sua imagem perante os distintos públicos.

No segundo capítulo, são descritos os procedimentos metodológicos e apresentado o método dialético, a visão teórico-metodológica adotada para a análise e interpretação dos dados levantados pela pesquisa.

No terceiro, são elencados conceitos com os quais são estabelecidos diálogos, dando ênfase ao conceito de comunicação para o desenvolvimento, porque entendemos que a comunicação, seguida por essa linha de estudo, pode ter um papel estratégico no processo de mudança social.

No quarto capítulo, é apresentada a análise dos dados coletados nas entrevistas realizadas com atores envolvidos no processo de comunicação e transferência de 
tecnologia da Embrapa, a partir do conjunto de categorias que foram elaboradas para referenciar a análise que ora apresentamos.

E, por último, são expostas as considerações finais, elaboradas a partir do conjunto de dados obtidos na pesquisa documental e no trabalho de campo e interpretados a partir do conjunto de objetivos delimitados para a realização desta dissertação.

Cabe salientar que a pesquisadora que desenvolve este trabalho tem um vínculo profissional com instituição aqui pesquisada. Atuando há dez anos como analista de comunicação em uma Unidade de Pesquisa da Embrapa. 


\section{AGRICULTURA FAMILIAR E EMBRAPA: O CONTEXTO DO ESTUDO}

A agricultura sempre ocupou um espaço central no desenvolvimento do Brasil, tanto que hoje, segundo Alan Bojanic, representante no Brasil da Organização das Nações Unidas para a Alimentação e Agricultura (FAO), o país é um candidato natural para tornar-se um dos maiores celeiros de alimentos do planeta nas próximas décadas.

Quanto ao cenário agrícola brasileiro, sabemos que ele vem sofrendo transformações com o passar do tempo. De acordo com Gasques et al. (2010), qualquer comparativo entre a década de 1970 e a atualidade mostra a adoção de novos padrões socioculturais e formatos econômico-produtivos, como ainda um período de mudanças das regiões rurais, sob um aspecto de espaços sociais, e da agropecuária, sob um aspecto de atividade econômica.

As mudanças também aconteceram com relação à capacidade de produção agrícola, que com o advento da tecnologia passou a impulsionar o crescimento do volume produzido, impactando fortemente o abastecimento do mercado doméstico e a exportação. As pesquisas desenvolvidas pela Embrapa, desde a sua criação em 1973, muito contribuíram para o aumento dessa eficiência produtiva.

E é em meio a esse contexto de transformações que a agricultura familiar desponta e passa a figurar como peça importante no cenário agrícola do país.

\subsection{A agricultura familiar na agenda nacional}

O segmento gera mais de $80 \%$ dos empregos e é responsável por cerca de $40 \%$ da produção agrícola nacional. A maior parte dos alimentos que abastecem a mesa dos brasileiros vem das pequenas propriedades e, em 2009, cerca de $60 \%$ dos alimentos que compuseram a cesta alimentar distribuída pela Companhia Nacional de Abastecimento (Conab) originaram-se da agricultura familiar ${ }^{1}$.

A agricultura familiar abarca diversas formas de fazer agricultura, que, de acordo com Schneider (2010), se diferenciam segundo os tipos diferentes de famílias, o contexto social, sua origem histórica, a interação com os diferentes ecossistemas, entre outros fatores. De norte a sul do país, é possível encontrar uma enorme diversidade de

\footnotetext{
${ }^{1}$ Dados disponíveis em: <http://www.conab.gov.br> Acesso em: 22 fev. 2015.
} 
agricultores familiares, muitos deles com denominações regionais e locais, tais como colono, sitiante, ribeirinho, etc.

Segundo Navarro (2010), a agricultura familiar, como tema da agenda nacional, entrou no cenário político apenas no início da década de 1990. Esse grupo de estabelecimentos produtivos de menor escala era até então designado como minifundiários, pequenos produtores, agricultores de subsistência ou, como era comum nos anos de 1970, agricultores de baixa renda. Na literatura, de forma geral, a atividade econômica desses produtores sempre foi denominada de pequena produção.

Podemos dizer com precisão que as origens da expressão agricultura familiar no Brasil, no momento em que ela é incorporada à agenda pública, estão na assinatura do Tratado de Assunção, que originou o Mercosul, em 1991, nas decorrentes ações político-sindicais comandadas pela Confederação Nacional dos Trabalhadores da Agricultura (Contag), e também na participação do antigo departamento rural da Central Única dos Trabalhadores (CUT), que deu origem à Federação dos Trabalhadores na Agricultura Familiar (Fetraf) (NAVARRO, 2010).

A promulgação do Tratado de Assunção e sua implementação levaram à criação de grupos de trabalho em diferentes ramos produtivos, que discutiam novas regras sobre importação, proteção de produtos etc. Contudo, não existiam canais de participação para os pequenos produtores dos quatro países que firmaram o acordo (Argentina, Uruguai, Paraguai e Brasil). A insatisfação com a exclusão desse grupo de produtores das negociações gerou pressão e articulações políticas que, por sua vez, levaram à construção de uma aliança de organizações de representação, cujo propósito era rever essa situação discriminatória.

No Brasil, quando da chegada de Itamar Franco ao governo, no final de 1992, a pressão por parte da CUT era para que os pequenos produtores recebessem suporte governamental de maior envergadura, em distintas áreas. Com esse foco, foi organizado no início 1993 um seminário sobre política agrícola em Belo Horizonte (MG), que reuniu representantes das federações agrícolas e de técnicos governamentais. Foi nesse evento que a expressão "agricultura familiar" passou a designar o conjunto de agricultores que até então vinham sendo designados imprecisamente por termos como pequenos produtores, minifundiários, camponeses, lavradores, colonos etc. ${ }^{2}$ A partir de

\footnotetext{
${ }^{2}$ Referências à agricultura centrada na produção familiar podem ser encontradas em diversas fontes, acadêmicas ou não, em épocas anteriores, mas o argumentado por Navarro é que a expressão "agricultura familiar" surge naquele período, tornando-se pública e de abrangência nacional, sendo institucionalizada pela primeira vez na história brasileira (NAVARRO, 2010, p.192).
} 
então, foram realizados outros seminários, em diferentes regiões, onde se debateu a integração desses produtores ao Mercosul, especialmente no que se refere à definição de políticas agrícolas diferenciadas. No mesmo ano, as articulações que aconteceram no âmbito dos quatro países do Mercosul, por meio de movimentos sindicais, acabaram por inserir as questões relativas à agricultura familiar na pauta da implementação do Tratado, e o tema passou também a encontrar espaço nos âmbitos governamentais (NAVARRO, 2010).

A noção de agricultura familiar mostrou-se capaz de englobar um conjunto de categorias sociais, tais como assentados, arrendatários, parceiros integrados a agroindústrias, entre muitos outros que não podiam mais ser identificados de forma confortável com as noções de pequenos produtores ou de trabalhadores rurais (SCHENEIDER, 2006).

Mas, só em 1995, durante o governo de Fernando Henrique Cardoso, surgem políticas públicas específicas para a agricultura familiar. Essas políticas são fruto de uma grande pressão por parte dos movimentos sociais, que chamaram a atenção do poder público para os agricultores de pequenas propriedades, que tinham a família como base do processo produtivo. Assim, surge, em 1996, o Programa Nacional de

Fortalecimento da Agricultura Familiar (Pronaf). O programa foi criado com a finalidade de prover crédito agrícola e apoio institucional às categorias de pequenos produtores rurais que vinham sendo excluídos das políticas públicas agrícolas ao longo da década de 1980 e encontravam sérias dificuldades de se manter na atividade (SCHNEIDER, 2006).

O governo seguinte, de Luiz Inácio Lula da Silva, não só manteve o Pronaf como também intensificou as ações e políticas governamentais que tinham a agricultura familiar como foco (MOLINA, 2004).

\subsubsection{Agricultura familiar: um novo retrato e um marco legal}

Em 2006, foi criada a Lei ${ }^{\circ} 11.326$ (BRASIL, 2006), que estabelece conceitos, princípios e instrumentos destinados à formulação das políticas públicas direcionadas à agricultura familiar e empreendimentos familiares rurais. Nela, o agricultor familiar está definido como aquele que pratica atividade no meio rural, atendendo simultaneamente a quatro requisitos: 
a) não ter, a qualquer título, área maior do que quatro módulos fiscais ${ }^{3}$;

b) utilizar principalmente mão de obra da própria família nas atividades econômicas de seu estabelecimento;

c) ter percentual mínimo da renda familiar originada de atividades econômicas do seu estabelecimento ou empreendimento, na forma definida pelo Poder Executivo;

d) dirigir seu estabelecimento ou empreendimento com sua família.

Essa lei foi inspirada em um trabalho realizado em conjunto pela FAO e pelo Incra, intitulado Novo Retrato da Agricultura Familiar, que definia o universo familiar como aquele integrado pelos estabelecimentos que atendiam, simultaneamente, às seguintes condições: direção dos trabalhos do estabelecimento exercida pelo produtor; trabalho familiar superior ao trabalho contratado e estabelecimentos com área não superior à máxima regional, estabelecida em 15 módulos fiscais. $\mathrm{O}$ trabalho $\mathrm{FAO} / \mathrm{Incra}$ amplia o escopo para agricultores de tamanho médio - até 15 módulos fiscais enquanto, nos critérios da lei, o conceito restringe-se aos pequenos produtores rurais até quatro módulos fiscais (GUANZIROLI et al., 2012).

A questão conceitual acerca da agricultura familiar ainda hoje não apresenta consenso entre estudiosos da área, nem entre órgãos governamentais e instituições ligadas ao segmento. Além disso, a agricultura familiar no Brasil é formada por subsegmentos, "que devem ser identificados para que se possa pensar com mais precisão em políticas públicas diferenciadas em relação a este setor" (GUANZIROLI et al., 2012, p.364). Esses subsegmentos, segundo Schneider (2010), que toma como base a proposta do sociólogo Van der Ploeg, estão divididos de acordo com as formas de produção rural, denominadas como "forma camponesa" e "forma empresarial".

[...]a agricultura familiar abrange duas constelações contrastantes: a forma camponesa e a forma empresarial de se fazer a agricultura. [...] A essência e as principais diferenças entre esses dois contrastantes modos de produção não residem tanto nas relações de propriedade; elas situam-se principalmente nas (diferentes) formas através das quais a produção, a distribuição e a apropriação de valor são ordenadas (PLOEG, 2006, apud SCHNEIDER, 2010, p.114).

\footnotetext{
${ }^{3}$ Módulo Fiscal (MF) é uma unidade de medida agrária que representa a área mínima necessária para as propriedades rurais poderem ser consideradas economicamente viáveis. Instituído pela Lei no 6.746/79, o módulo fiscal apresenta tamanhos que podem variar de 5 a 110 hectares, conforme o município. O módulo fiscal serve de parâmetro para a classificação fundiária dos imóveis rurais do município quanto ao seu tamanho, em conformidade com o art. $4^{\circ}$ da Lei $\mathrm{n}^{\circ}$ 8.629/93. Para tanto, as propriedades rurais podem ser classificadas em: minifúndios: com tamanho de até um módulo fiscal; pequenas propriedades: com área entre um e quatro módulos fiscais; médias propriedades: com dimensão superior a quatro até 15 módulos fiscais e grandes propriedades: com área maior do que 15 módulos (LANDAU et al., 2012).
} 
O trabalho realizado pela FAO/Incra, que resultou no estudo Novo Retrato da Agricultura Familiar: o Brasil Redescoberto (MDA/INCRA/FAO, 2000), tornou-se a principal referência no debate público sobre a agricultura familiar e foi responsável por mostrar ao país uma realidade diferente sobre a contribuição e a importância desse setor para o desenvolvimento do Brasil. O estudo atualizava o retrato da agricultura brasileira em geral e destacava a agricultura familiar, "muito mais robusta e relevante do ponto de vista econômico e social do que aquela que era apresentada pela visão dominante da 'pequena produção de subsistência"” (GUANZIROLI et al., 2012, p. 352).

Ainda com o foco em retratar a real situação da agricultura familiar no Brasil, o último Censo Agropecuário publicado em 2007 pelo Instituto Brasileiro de Geografia e Estatística (IBGE) traz pela primeira vez estatísticas oficiais sobre o segmento, apresentadas em um caderno específico intitulado Agricultura Familiar: Primeiros Resultados $^{4}$. A partir desse censo foi identificado que a agricultura familiar no Brasil conta com 4,3 milhões de unidades produtivas, o que corresponde a $84,4 \%$ dos estabelecimentos agropecuários do país e a 74\% da mão de obra do campo e que o setor é responsável pela produção da maioria dos alimentos consumidos todos os dias pelos brasileiros e por $33 \%$ do valor bruto da produção de alimentos.

\subsection{Embrapa: uma história e um contexto}

Criada em 26 de abril de $1973^{5}$, a Embrapa é uma empresa pública reconhecida, no Brasil e no exterior, como a principal instituição no mundo em pesquisas voltadas para a agricultura tropical (FUCK et al., 2007). Vinculada ao Ministério da Agricultura, Pecuária e Abastecimento, tem como missão "viabilizar soluções de pesquisa, desenvolvimento e inovação para a sustentabilidade da agricultura, em benefício da sociedade brasileira" 6 . Atuando por intermédio de centros de pesquisa e de Unidades de serviços e administrativas, a Embrapa está presente em quase todos os estados da

\footnotetext{
${ }^{4}$ Censo Agropecuário 2006. Agricultura Familiar. Primeiros resultados. Brasil, Grandes Regiões e Unidades da Federação (IBGE, 2009).

5 Também no início da década 1970, durante a consolidação do processo de modernização agrícola, foi criada a Empresa Brasileira de Assistência Técnica e Extensão Rural (Embrater), que foi extinta pelo governo Collor. A Embrapa e a Embrater foram criadas com o propósito de aumentar a produtividade agrícola por meio da geração e pela oferta de tecnologias, respectivamente.

6 Dados disponíveis em: www.embrapa.br. Acesso em: 22 nov. 2013
} 
Federação e possui, aproximadamente, 9.800 empregados, dos quais 2.474 são pesquisadores. Para 2015, o orçamento da empresa é de R \$ 2,8 bilhões ${ }^{7}$.

De acordo com Salles-Filho et al. (2000), a criação da Embrapa representou uma iniciativa do governo federal para centralizar e focar a política agrícola na tecnologia agropecuária, tendo sua instalação sido pautada pela difusão de tecnologia moderna, articulação com o ambiente externo para prospecção de demandas do universo agrícola e enfoque multidisciplinar no desenvolvimento da pesquisa. Ainda, segundo os autores, em seus primeiros anos de funcionamento, a Embrapa se dedicou ao desenvolvimento de pesquisa agropecuária que facilitava a incorporação de tecnologias agrícolas disponibilizadas pela indústria de máquinas, equipamentos e insumos e do estreitamento da relação com a agroindústria processadora. Na década de 1980, houve uma reversão nesse papel e a Embrapa passou a atuar na geração de novas tecnologias. Atualmente, existe uma tendência da empresa em buscar capacitação profissional para a solução de problemas específicos. A formulação de políticas públicas é fortemente executada pela Embrapa, garantindo-lhe legitimidade e sustentabilidade institucional (SALLES-FILHO et al., 2000).

A Embrapa é responsável pela coordenação do Sistema Nacional de Pesquisa Agropecuária (SNPA) ${ }^{8}$, cujas tecnologias geradas mudaram o perfil da agricultura brasileira. Como exemplo, podemos citar que no período entre 1976 e 2011 a área destinada ao cultivo de grãos e sementes oleaginosas aumentou 43,92\% no país, enquanto a produção dessas culturas aumentou por volta de $249,56 \%$ e os rendimentos gerados por elas 2,4 vezes. Tendências similares foram observadas no setor de carne. A produção de carnes bovina, suína e de aves aumentou de forma gradual de 4.270 mil toneladas métricas, em 1978, para 24.673 mil toneladas métricas em 2011. A produção de leite também merece ser destacada, pois esta aumentou significativamente de 11,16 bilhões de litros, em 1980, para 32,09 bilhões de litros em 2011. ${ }^{9}$

Como não faz parte da missão da Embrapa atender diretamente aos agricultores, público ao qual se destinam as tecnologias geradas, a empresa precisa contar com o

\footnotetext{
${ }^{7}$ Informações disponíveis no documento Embrapa em Números (2015).

${ }^{8}$ Sistema constituído por instituições públicas federais, estaduais, universidades, empresas privadas e fundações, que, de forma cooperada, executam pesquisas nas diferentes áreas geográficas e campos do conhecimento científico. Seus objetivos são: assegurar constante organização e coordenação das instituições que compõem o sistema; favorecer o desenvolvimento de um sistema nacional de planejamento para pesquisa; proporcionar a execução conjunta de projetos de pesquisa de interesse comum; e coordenar o esforço de pesquisa para atendimento às demandas de regiões, estados e municípios (FUCK, 2005).

${ }_{9}^{9}$ Dados disponíveis em: www.embrapa.br. Acesso em: 22 nov. 2013
} 
suporte das empresas de Assistência Técnica e Extensão Rural (Ater) ${ }^{10}$, que são capilares e estão presentes em todas as regiões do país. Com o propósito de que a tecnologia chegue até o produtor, a empresa costuma utilizar estratégias de assessoria de imprensa, visando a divulgação em massa, e, em menor proporção, a organização de eventos, como dias de campo, cursos e palestras.

Com o enfoque desenvolvimentista de aumento produtivo adotado pelo Brasil nos anos 1970 do século passado, a Embrapa teve por muito tempo sua imagem associada à geração de tecnologias para grandes produtores, chegando mesmo a conotar inexpressivo engajamento da maioria de suas Unidades e pouco interesse dos pesquisadores em relação à agricultura familiar (MARQUES et al., 2006). Mas, hoje, essa realidade já se mostra diferente, visto que a empresa desenvolve pesquisas diretamente para esse segmento, fato que já possibilita vincular a imagem da empresa com a agricultura familiar. Em 2005, por meio de uma demanda do governo federal, foi criado o Macroprograma $6^{11}$, específico para submissão de projetos de pesquisa que tenham como tema a agricultura familiar, com financiamento de até R $\$ 420$ mil por projeto. Em maio de 2015, constavam em execução 59 projetos de pesquisa no Macroprograma 6, sendo 11 co-financiados por outras entidades brasileiras de fomento a pesquisa $^{12}$.

Entre 2009 e 2013, o investimento em pesquisa e desenvolvimento realizado pela Embrapa em agricultura familiar, agricultura orgânica e agroecologia foi por volta de $\mathrm{R} \$ 1,5$ bilhão, cerca de $15 \%$ do orçamento total da empresa no período.

\footnotetext{
${ }^{10} \mathrm{O}$ modelo de serviços de Ater institucionalizado no Brasil foi o público e gratuito e teve seu auge durante o período de modernização agrícola, na década de 1970 e início da de 1980 , em associação às políticas de crédito rural e pesquisa agropecuária. Porém, a década de 1980 foi marcada por mudanças na política agrícola, privilegiando outros instrumentos de fomento à agropecuária, e pela redução da disponibilidade dos recursos governamentais para o crédito rural e para o serviço de Ater, deflagrando uma crise no Sistema Brasileiro de Assistência Técnica e Extensão Rural (Sibrater), que culminou com a extinção, em 1990, da Embrater, coordenadora do Sistema. A partir de meados da década de 1990, as ações da sociedade civil organizada (produtores e trabalhadores rurais, extensionistas, etc.) lograram a criação de novas políticas públicas voltadas para a agricultura familiar e evidenciaram a necessidade do resgate dos serviços de Ater, agora com maior participação de atores privados. Desde 2003, o MDA passou a ser o principal responsável pelas políticas voltadas para a Ater, lançando em 2004 uma Política e um Programa nacional para o setor, mas, até hoje, mais de dez anos depois, ainda não aconteceu uma reestruturação efetiva do Sibrater. Cabe salientar que a crise na extensão rural ainda é um problema real e atual, uma vez que os principais agentes de Ater, voltados para o público majoritário da agricultura familiar, são as instituições estaduais, que não vêm recebendo dos respectivos governos os recursos (humanos, orçamentários, materiais) necessários ao atendimento da demanda existente (PEIXOTO, 2008).

${ }^{11}$ São programas que orientam a gestão das carteiras de projetos e processos da Embrapa. Em número de seis, cada macroprograma possui projetos, financiamento e formas de indução de projetos específicos, que atuam como instrumentos para cumprimento de metas técnicas. Informação disponível em <https:intranet4.sede.embrapa.br>. Acesso em: 31 out. 2013

${ }^{12}$ Informação retirada do documento Embrapa em Números (2015).
} 
Esse valor abrange um conjunto de custos: custeio direto dos projetos, custeio indireto e de pessoal e é referente a toda a carteira do Macroprograma 6 e projetos de transferência de tecnologia ligados ao Macroprograma 4, relacionado ao tema da agricultura familiar $^{13}$.

De acordo com a publicação Embrapa em Números (2015), 65\% dos projetos da empresa resultam em tecnologias e informações que podem beneficiar agricultores familiares em todas as regiões do Brasil, agregando valor às suas atividades e promovendo o desenvolvimento sustentável, além de validar e transferir tecnologias e produtos para esses produtores.

\subsubsection{A comunicação na Embrapa}

Com relação à comunicação, as primeiras ações da Embrapa datam do ano de sua criação. Na época não havia estrutura formalizada em um setor específico, e o trabalho nessa área era desenvolvido em torno da mera divulgação de informações por um assessor de imprensa vinculado ao gabinete do presidente da empresa. A primeira equipe de comunicação começou a ser montada em 1977, com a contratação de um jornalista e de um profissional de relações públicas. Até o fim da década de 1980, a comunicação era basicamente uma ferramenta para transferência de tecnologia e as atividades de comunicação muitas vezes eram coordenadas por profissionais de agronomia ou veterinária, desarticuladas institucionalmente e voltadas basicamente para comunicação com produtores rurais (SILVA e DUARTE, 2007). Hoje, a realidade é bastante diferente, pois a empresa conta com 206 profissionais com formação em comunicação social, dos quais 42 estão lotados na Sede da empresa, em Brasília (DF), e 164 estão distribuídos pelos 47 centros de pesquisa e Unidades de serviço ${ }^{14}$.

Com o desmonte do Sistema Brasileiro de Assistência Técnica e Extensão Rural (Sibrater), em 1990, e a partir da extinção da Embrater, a Embrapa passou a criar canais próprios para a comunicação e a difusão tecnológica de seus resultados de pesquisa. $\mathrm{Na}$ época, a maior parte dos resultados de pesquisa da empresa passou a ser divulgada em linguagem jornalística para o público em geral, por intermédio de veículos de comunicação de massa, e produtos de promoção institucional. Existiam também algumas poucas experiências, como programas de rádio ou TV dirigidos para os

\footnotetext{
${ }^{13}$ Informação fornecida pela Secretaria de Comunicação Social da Embrapa (Secom).

${ }^{14}$ Informação fornecida pela Secretaria de Comunicação Social da Embrapa (Secom).
} 
produtores rurais, mas que ainda assim não tinham especificamente como público-alvo a agricultura familiar (BELTRÃO, 2010) ${ }^{15}$.

Já em meados de 1990, a comunicação da empresa foi gradativamente se estruturando, tendo talvez como ponto original do processo a contratação de profissionais por meio de concurso público e, em segundo lugar, a definição e formalização, pela primeira vez, de uma política de comunicação. Em 1995, cria-se um grupo para construção do documento, sendo, no ano seguinte, formalizada a Política de Comunicação da Embrapa, que tinha como objetivos contribuir para o cumprimento da missão institucional da empresa e funcionar como instrumento orientador e normativo das ações de comunicação. Em 2002, acontece a primeira revisão do documento (SILVA e DUARTE, 2007).

Em 2011, a área responsável pela comunicação corporativa da Embrapa deixa o status de assessoria e passa a Secretaria de Comunicação (Secom), e, nas Unidades de pesquisa, a comunicação passa a funcionar como núcleo, separando-se das áreas de transferência de tecnologia. Essa nova configuração da comunicação na Embrapa teve como propósito colocar a área em um novo patamar na instituição, aumentando seu poder estratégico e político. No mesmo ano, é criado o Departamento de Transferência de Tecnologia (DTT), na Sede da empresa, que também passa a realizar atividades/ações de comunicação, mas sem nenhum documento balizador. Há ainda ações de comunicação coordenadas pela Embrapa Informação Tecnológica, Unidade de serviço da Embrapa responsável por atividades como publicações, o programa de televisão Dia de Campo na TV e o programa de rádio Prosa Rural, tendo este último a agricultura familiar como público-alvo. A Embrapa Informação Tecnológica é uma Unidade independente que não está vinculada administrativamente à Secom e nem ao DTT.

\subsubsection{A imagem da Embrapa diagnosticada a partir de uma pesquisa}

De forma estratégica, a Politica de Comunicação da Embrapa preconiza o monitoramento da imagem da empresa por meio de frequentes pesquisas. A última ${ }^{16}$,

\footnotetext{
${ }^{15}$ Tradando-se especificamente da transferência de tecnologia, atualmente a Embrapa desenvolve diversas ações com esse foco, que podem ser diferentes de acordo com a atuação e o planejamento de cada Unidade. As principais ferramentas utilizadas são eventos (dias de campo, cursos, palestras etc.), publicações (cartilhas, instruções técnicas, panfletos etc) e ainda a participação em feiras e exposições que tenham como tema a agropecuária.
} 
realizada entre 2011 e 2012, levantou dados bastante interessantes. De forma ampla, a pesquisa de imagem sinalizou que os públicos, tanto interno quanto externo, têm uma boa impressão acerca da Embrapa e da forma como cumpre o seu papel. São apontados por todos os segmentos pesquisados atributos como seriedade, idoneidade e eficiência na área de pesquisa, mas também uma possível deficiência na atuação junto à agricultura familiar, com indicação de entraves na comunicação com este público específico.

Por meio da pesquisa foi possível verificar que, internamente, considera-se que a Embrapa obteve melhora na comunicação com seus públicos durante a última década, mas que esta desenvolve poucas ações voltadas aos produtores rurais menos capitalizados, apresentando ainda problemas na decodificação da informação científica produzida pela área de pesquisa.

Foi verificado ainda, junto ao público interno, que ocupa cargo gerencial, uma divisão de opiniões acerca da inserção e influência da Embrapa nos contextos da agricultura familiar, agronegócios, assistência técnica e extensão rural. Muitos consideram que a empresa deveria trabalhar exclusivamente com um ou outro segmento. Ainda para esse público, mesmo considerando adequado o foco de atuação no desenvolvimento de tecnologias, existem ressalvas no que tange à transferência das tecnologias produzidas e à aplicação do conhecimento gerado, cujas atividades não vêm sendo realizadas satisfatoriamente, conforme opinião manifestada na pesquisa de imagem.

De acordo com a percepção do público externo, a Embrapa tem uma boa comunicação com seus públicos, mas apresenta dificuldades com alguns públicos específicos, tais como agricultores familiares e consumidores urbanos. A forma como a empresa se relaciona com os diferentes segmentos de produtores rurais também foi avaliada na pesquisa. Foi observada uma intensa polarização entre os segmentos agronegócio e agricultura familiar, na opinião dos entrevistados sobre a atuação da

\footnotetext{
${ }^{16}$ A pesquisa de imagem envolveu dois agrupamentos de públicos (interno e externo) e foi desenvolvida em quatro etapas: entrevistas em profundidade com dirigentes da Embrapa; survey quantitativo com empregados e supervisores de Núcleos de Comunicação das Unidades de Pesquisa; entrevistas em profundidade com públicos de interesse; survey quantitativo com públicos de interesse da Embrapa. Em âmbito externo, a pesquisa foi aplicada a 14 segmentos, entre eles: imprensa, agentes de transferência de tecnologia, consumidores urbanos, parlamentares, produtores rurais (pequenos/ médios e grandes), institutos de pesquisa agropecuária e comunidade científica. Foram realizadas 126 entrevistas em profundidade e 2.400 surveys. Essa pesquisa de imagem foi coordenada pela Secretaria de Comunicação da instituição e executada pela Meta Instituto de Pesquisas de Opinião. Seu objetivo foi buscar subsídios para a compreensão das atuais percepções, demandas e expectativas dos públicos de interesse da Embrapa.
} 
Embrapa junto aos produtores rurais. Por um lado, um grupo de entrevistados acredita que a Embrapa atua de modo a atender todos os segmentos da agropecuária, embora os grandes produtores tenham acesso mais facilitado às tecnologias, informações e produtos disponibilizados pela empresa. Mas, por outro lado, é apontado pela maioria dos entrevistados que a Embrapa mantém seu foco na agricultura de grande escala, relegando a agricultura familiar a segundo plano.

Quando questionados sobre as áreas em que a Embrapa deveria aumentar a sua atuação, os entrevistados dividiram as suas opiniões da seguinte forma: $35,5 \%$ acreditam que a Embrapa deva aumentar seus esforços em favor da agricultura familiar; outros 18,1\% disseram que a Embrapa deve atuar mais fortemente junto aos pequenos produtores rurais. $\mathrm{O}$ aumento da atuação da empresa em pesquisa na agricultura foi referido por $11,3 \%$ dos respondentes, e a sustentabilidade ambiental foi citada por $9,1 \%$. Um total de $24,2 \%$ dos entrevistados não soube responder à questão e $1,8 \%$ restante tiveram opiniões diversas, tais como atuação junto a consumidores urbanos, comunidades tradicionais, publicação de artigos científicos etc. Entre os públicos que entendem ser necessário que a Embrapa invista mais na área de agricultura familiar, destacam-se os agentes de extensão rural, a comunidade científica, a imprensa, os poderes Executivo e Legislativo e os produtores rurais.

Assim, a partir da análise dos relatórios da pesquisa de imagem, percebemos que de forma geral os processos de comunicação da Embrapa com seus públicos de interesse são satisfatórios, exceto no que se refere à comunicação da empresa com os segmentos de agricultores familiares, comunidades tradicionais e assentados da reforma agrária.

Quanto à comunicação para a transferência de tecnologia, foi percebida uma concordância entre os diversos públicos da instituição sobre o fato de que essa também tem se mostrado ineficiente para com esse segmento.

\subsection{Comunicação, transferência de tecnologia e agricultura familiar para a} Embrapa: o olhar a partir dos documentos institucionais

Buscando conhecer o posicionamento da Embrapa com relação aos temas que permeiam este trabalho, foi realizada uma análise dos documentos nos quais se estabelecem os parâmetros da Política de Comunicação da Embrapa, publicados em 2002, bem como da versão anterior, de 1996, visando conhecer e comparar as versões, 
verificando suas diferenças e identificando como a comunicação é apresentada hoje e qual o papel que ela ocupa na Embrapa, bem como em que contextos são abordados os temas transferência de tecnologia e agricultura familiar. Seguindo a mesma linha de análise, também foi realizada a leitura do Plano Diretor da Embrapa - PDE (2008 2023), que explicita o conjunto de ações estratégicas da instituição para os próximos anos, e uma proposta do Departamento de Transferência de Tecnologia para um marco referencial sobre transferência de tecnologia, intercâmbio e construção do conhecimento, que tem como princípio subsidiar a integração entre macroprocessos institucionais ${ }^{17}$ no setor e orientar os procedimentos que visam promover a interação entre a Embrapa e a sociedade.

\subsubsection{A Política de Comunicação da Embrapa}

Como demonstramos anteriormente, em meados de 1990, a comunicação da Embrapa foi gradativamente se estruturando, tendo talvez como ponto original do processo a contratação de profissionais por meio de concurso público e, em segundo lugar, a definição e formalização de uma política de comunicação. Em 1995, cria-se um grupo técnico para a elaboração do documento, sendo, no ano seguinte, formalizada a Política de Comunicação da Embrapa, que tinha como objetivos contribuir para o cumprimento da missão institucional da empresa e servir como instrumento orientador e normativo das ações de comunicação (SILVA e DUARTE, 2007).

Publicada em 1996, a primeira edição desse documento incluía na apresentação um posicionamento institucional em que a comunicação na Embrapa era entendida como um "insumo estratégico, integrado ao processo de tomada de decisões" e que a materialização de uma Política para o setor expressava a disposição da instituição de integrar ações e estratégias de comunicação em uma nova proposta, que contemplaria uma maior interação com o mercado e a sociedade.

A partir desse primeiro documento, além de serem estipuladas diversas orientações com relação à comunicação na Embrapa e procedimentos que deveriam ser observados por todos os empregados que de alguma forma estabelecessem comunicação com a sociedade, foi definido um conceito de comunicação empresarial, bem como explicitados os valores, objetivos e diretrizes para a área. Além de fixar os perfis dos

\footnotetext{
${ }^{17}$ O Sistema Embrapa de Gestão organiza atualmente as suas ações a partir de três macroprocessos: pesquisa e desenvolvimento, transferência de tecnologia e administração e finanças.
} 
públicos de interesse da instituição, foram criados ainda, de acordo com a Política de Comunicação, manuais de eventos, estruturas de assessoria de imprensa e de produção de textos jornalísticos, e também se passou a formular propostas de pesquisas de imagem e até mesmo de mudanças da identidade visual da marca gráfica institucional, buscando-se uma unicidade da imagem da empresa no espaço público.

Em 2002, entendendo que as políticas são datadas e que necessitam estar em sintonia com o tempo histórico, a Embrapa realiza a primeira revisão do documento, mas mantém os princípios básicos inicialmente estabelecidos, ou seja, "a comunicação é um processo que compete a todos e exige capacitação. Ela deve vislumbrar, ao mesmo tempo, o cliente e o cidadão e se constituir num autêntico sistema de inteligência empresarial" (EMBRAPA, 2002, p.8).

Em linhas gerais, não houve mudanças com relação à forma de se fazer comunicação na empresa, mas sim ajustes com relação a mudanças significativas pelas quais tanto o universo da comunicação quanto o da gestão empresarial vinham passando. Com a alteração de cenários, fez-se necessária para a instituição "a ampliação e o refinamento dos conceitos, o redimensionamento dos canais de relacionamento com os stakeholders ${ }^{18}$, explicitação das tangências entre os focos institucional e mercadológico e a consolidação da comunicação como insumo estratégico" (EMBRAPA, 2002, p.7).

Dessa forma, na nova versão do documento que sustenta a sua política, a Embrapa reconhece a necessidade de criar canais de comunicação segmentados para melhor se adequar ao perfil diverso de seus públicos de interesse e coloca a comunicação como um instrumento de inteligência empresarial: "isso significa encarar o trabalho de relacionamento com o público de interesse a partir de uma perspectiva estratégica, ou seja, vinculada ao processo de tomada de decisão e respaldada em ações e metodologias sintonizadas com este objetivo" (EMBRAPA, 2002, p.83).

$\mathrm{Na}$ primeira versão, a Política de Comunicação previa que as diferentes modalidades de Comunicação existentes na empresa - Administrativa, Científica, Governamental, Mercadológica, Social e para Transferência de Tecnologia respondessem pela execução de trabalhos específicos, sem, no entanto, perder de vista a articulação entre si. Na revisão, essas modalidades foram agrupadas em duas novas

\footnotetext{
${ }^{18}$ Stakeholders são todas as pessoas que possuem interesses em relação à organização e são capazes de influenciá-la, tais como acionista, governo, consumidores, comunidade, funcionários, mídia etc. Assim como os stakeholders podem ser afetados pelas ações das organizações, eles também podem influenciar decisões e políticas de uma organização (FRANÇA, 2004, p.59 - 60).
} 
grandes categorias estabelecidas como focos principais da comunicação - o institucional ou corporativo, e o mercadológico. O institucional tem como objetivo criar e reforçar relacionamentos para promover a legitimação da empresa diante de um conjunto diversificado de públicos de interesse (empregados, clientes, governo, comunidade científica, imprensa etc.), pela explicitação, sobretudo, de informações que clarifiquem o modo como a empresa deseja se inserir no mercado e na sociedade. Já o mercadológico tem como foco "apoiar o processo de transferência de tecnologia" em distintos segmentos da cadeia produtiva da agricultura (EMBRAPA, 2002, p. 46).

Mais detalhadamente, o documento indica que o foco institucional deve priorizar “a implementação e a manutenção de ações, fluxos, e canais que contribuem para dar visibilidade à gestão administrativa e a filosofia negocial, à competência técnica e científica da Embrapa" e o mercadológico deve favorecer "a incorporação das tecnologias e conhecimentos gerados ao processo produtivo, bem como a obtenção de informações que contribuam para o contínuo desenvolvimento de tecnologias que indiquem à Empresa novas demandas" (EMBRAPA, 2002, p. 40 e 46).

Na nova versão, o fato de a modalidade mercadológica abarcar a transferência de tecnologia parece, de certa forma, ter diminuído a importância da comunicação para a transferência de tecnologia, o que se percebe quando se verifica no documento que o tópico que trata da comunicação institucional é detalhado e claro, enquanto no que tange à comunicação voltada para o foco mercadológico, é tratado de forma ampla, com direcionamentos de caráter geral.

Com relação à definição do foco mercadológico na política de comunicação, foi verificado que no documento esse foco se materializa, sobretudo, pela formatação de conteúdos técnicos e especializados, adequados ao perfil do público a que se destina, levando em conta suas expectativas, demandas e necessidades. E, tendo em vista sua vinculação prioritária com clientes e usuários, articula-se necessariamente com a pesquisa e desenvolvimento e está sintonizado, em seu processo final, com a promoção de produtos e serviços.

Há ainda um posicionamento sobre a relação entre comunicação, pesquisa e desenvolvimento e transferência de tecnologia, instâncias que "devem buscar a integração, reunindo esforços no sentido de maximizar o relacionamento com os públicos de interesse e consolidar a imagem ou reputação da Empresa". No documento, percebemos que a instituição considera que a comunicação e a transferência de tecnologia têm um papel relevante a desempenhar, quando incorporado à massa crítica 
que sustenta o processo de tomada de decisões, desde a prospecção de demandas, passando pelos projetos de pesquisa, até a disponibilização para o mercado e a sociedade de produtos e soluções desenvolvidas pela Embrapa (EMBRAPA, 2002, p. $50)$.

Exclusivamente sobre as normatizações dos procedimentos e as demais orientações voltadas para o processo de transferência de tecnologia, encontramos no documento uma indicação para a política de transferência de tecnologia, mas salientamos que não há atualmente uma política de transferência de tecnologia que esteja vigente na instituição. Hoje, o documento que se propõe a orientar a transferência na Embrapa é o Marco Referencial de Transferência de Tecnologia, Intercâmbio e Construção Coletiva do Conhecimento, que ainda está em fase de aprovação e que será apresentado neste trabalho em um próximo tópico.

$\mathrm{Na}$ Política de Comunicação estão expostos ainda alguns impasses vividos pela instituição diante dos dilemas e desafios apresentados pelo contexto agrícola da época. Entre eles, aparece a relação complexa entre o meio ambiente e o agronegócio e o "aparente conflito entre o desenvolvimento agroindustrial e a qualidade de vida no campo", questões de difícil diálogo e convivência, materializadas entre os segmentos sociais ou profissionais e entre grupos políticos que os representam, pois as discussões acerca desses temas estão sempre pautadas pela ingerência de concepções políticas, filosóficas e até ideológicas (EMBRAPA, 2002, p.19).

E é dentro desse cenário, de dilemas e desafios, que a agricultura familiar é citada no documento, sendo o seu fortalecimento entendido como um importante elemento nesse contexto, visto que o segmento, dentro e fora do país, "tem merecido a atenção dos governantes, dos especialistas no agribusiness e mesmo da sociedade civil que vê, nesta alternativa, um fator importante para fixar o homem do campo, resgatar a sua cidadania e também incorporá-lo ao mercado" (EMBRAPA, 2002, p.20).

\subsubsection{Marco Referencial de Transferência de Tecnologia, Intercâmbio e Construção Coletiva do Conhecimento - Fundamentos sobre a interação entre a Embrapa e a sociedade ${ }^{19}$}

\footnotetext{
${ }^{19}$ Este documento é considerado uma proposta, uma vez que até o mês de julho de 2015, segundo informações do Departamento de Transferência de Tecnologia, ainda se encontra em fase de aprovação pela Presidência da Embrapa.
} 
O Marco Referencial de Transferência de Tecnologia, Intercâmbio e Construção Coletiva do Conhecimento é uma proposta elaborada pelo Departamento de Transferência de Tecnologia com o objetivo de subsidiar a integração entre os macroprocessos institucionais e orientar a interação entre a Embrapa e a sociedade, direcionando para a qualificação das ações de transferência de tecnologia da instituição e a adoção do intercâmbio e construção coletiva do conhecimento entre a empresa e os agricultores, considerando a diversidade e heterogeneidade da agricultura brasileira e tropical.

O documento parte de uma nova proposta de se fazer transferência de tecnologia, com foco maior nas pessoas para as quais elas são desenvolvidas. Uma das primeiras observações do documento é que "as modelagens indutoras, demarcadas pela difusão de tecnologias, cumpriram o papel de levar informações para os diferentes públicos, mas precisam ser fortemente repensadas", salientando que até organizações privadas envolvidas no esforço competitivo de inovação reviram seus métodos e adotaram valores que destacam a relação com as pessoas e o foco nas suas demandas e necessidades (EMBRAPA, 2014, p.2).

Também chama atenção para especificidades locais e necessidade de ajustes para a geração e a apropriação de conhecimentos, como ainda para a necessidade do reconhecimento do impacto gerado pela informação e pela tecnologia na vida dos usuários.

O Marco Referencial coloca como um ponto essencial e emergente de aprendizado da Embrapa o reconhecimento das inúmeras agriculturas que compõem o cenário do setor no país, considerando a enorme gama de agricultores que produzem em diferentes escalas, e a partir de diversas formações culturais, identidades e de formas próprias de organização e obtenção de informação. Entendendo ainda que nesse cenário "não é mais factível, nem tampouco producente, implementar uma única trajetória de desenvolvimento, com base somente no modelo linear de transferência de tecnologias" (EMBRAPA, 2014, p.4).

Quanto à importância atribuída para algumas áreas estruturais da Embrapa, no Marco Referencial a posição adotada é que "pesquisa e desenvolvimento, transferência de tecnologia, intercâmbio e construção coletiva de conhecimentos, para além de estarem formal e organicamente integrados, desempenham papéis complementares e de igual importância para a efetivação do processo de inovação tecnológica" (EMBRAPA, 2014, p.5). 
Assim, para que seja de fato adotada essa nova forma de se fazer transferência de tecnologia, são indicadas algumas diretrizes: elevar o macroprocesso de transferência de tecnologia à mesma dimensão institucional do macroprocesso de pesquisa e desenvolvimento; integrar pesquisa e desenvolvimento, transferência de tecnologia e comunicação e negócios desde o início do processo de gestão da inovação; promover o diálogo com parceiros na definição de estratégias de transferência de tecnologia, intercâmbio e construção coletiva de conhecimentos, considerando as características dos diferentes públicos e a diversidade dos agroecossistemas; estimular o protagonismo dos atores sociais como sujeitos do processo de inovação; e valorizar e apoiar as redes locais de inovação nos processos de transferência de tecnologia, intercâmbio e construção de conhecimentos.

O Marco Referencial propõe ainda bases conceituais para nortear a interação entre a Embrapa e a sociedade, tendo como foco principal os elos da cadeia produtiva. Essas bases são a transferência de tecnologia, o intercâmbio e construção coletiva do conhecimento, cujos conceitos adotados no documento são os seguintes:

Entende-se transferência de tecnologia como um componente do processo de inovação, no qual diferentes estratégias de comunicação e interação são utilizadas por grupos de atores com o objetivo de dinamizar arranjos produtivos, mercadológicos e institucionais, por meio da difusão de soluções tecnológicas (EMBRAPA, 2014, p.7).

O intercâmbio de conhecimentos pressupõe abordagens participativas e interdisciplinares com o reconhecimento de sujeitos que têm diferentes visões e expectativas. Neste quadro plural e dialógico desenvolvem-se diferentes trajetórias tecnológicas. Por um lado, o enfoque interativo permite que tecnologias e conhecimentos já desenvolvidos sejam interpretados e adaptados, mediante realidades específicas e valores particulares (EMBRAPA, 2014, p.7).

A construção coletiva do conhecimento é um processo de interação baseada na força dialógica no qual um conjunto de atores observa a realidade e com as pessoas do local sistematiza informações em busca de soluções tecnológicas no contexto de sua aplicação (EMBRAPA, 2014, p.8).

É apontado pelo Marco Referencial que a grande maioria das ações de transferência de tecnologia na Embrapa ainda são orientadas pelo paradigma difusionista, que está baseado no processo linear de geração, validação, transferência e adoção de tecnologias, onde pacotes tecnológicos são transferidos/difundidos para os agricultores pelos serviços de assistência técnica e extensão rural. Mas também é pontuado que a Embrapa tem avançado no enfoque de intercâmbio de conhecimento, 
em que há o deslocamento da lógica da oferta unidirecional de tecnologias para outra em que as demandas são a principal referência que alimenta um processo de troca que deve ser dialógico.

E é dentro desse contexto que o Marco Referencial propõe a adoção de uma nova forma de se fazer comunicação na Embrapa, uma vez que "os processos participativos inaugurados com os modelos interativos voltados a inovação agropecuária evidenciam a crescente necessidade de novas abordagens comunicacionais, além da de caráter essencialmente institucional” (EMBRAPA, 2014, p.11).

Assim, é evidenciada a necessidade de se tratar da comunicação para o desenvolvimento, descrita no Marco Referencial como uma "modalidade que valoriza o sistema de percepção e de valores dos sujeitos sociais, numa visão dialógica que requer novas habilidades - por certo mais perspicazes - dos profissionais envolvidos (pesquisadores, técnicos e comunicadores)"(EMBRAPA, 2014, p.11).

A comunicação para o desenvolvimento, de acordo com o documento, deveria ser uma concepção institucionalizada, tornando-se referência para interações internas e externas na Embrapa. "Trata-se de comunicação com o fermento da participação e tudo indica que as mudanças ocorrem quando as pessoas se sentem agentes do processo, como atores e não como objetos das políticas” (EMBRAPA, 2014, p.14).

No Marco Referencial é apontada ainda, e de forma crítica, a não equivalência na instituição dos macroprocessos de transferência de tecnologia e de pesquisa e desenvolvimento. No decorrer do texto, é pontuada a necessidade de colocá-los na mesma dimensão, e essa assimetria diagnosticada é tratada como impedimento para que "se concretize de forma célere os processos de inovação, seja pela carência de profissionais seja pela qualificação insuficiente ou inadequada, ou ainda com a dificuldade de comunicação com agentes de extensão rural, cooperativas, associações, agricultores e a iniciativa privada, dentre outros" (EMBRAPA, 2014, p. 13).

A questão mais sensível no contexto apresentado é o modo de interagir da Embrapa com os diferentes atores no setor agrícola e com as instituições externas. $\mathrm{O}$ fortalecimento de parcerias é indicado como forma de ampliar o acesso à informação e como facilitador na incorporação de tecnologias pelos sistemas produtivos, uma vez que a Embrapa não faz assistência técnica e extensão rural, mas depende desses processos para ajudar a promover o desenvolvimento ao disseminar o conhecimento gerado por suas investigações. 
Quanto à agricultura familiar, o documento não faz nenhuma referência específica, mas quando se propõe a trabalhar com as diversas agriculturas brasileiras, entende-se que o segmento esteja incluído nessa perspectiva.

\subsubsection{Plano Diretor da Embrapa (PDE)}

O Plano Diretor da Embrapa (PDE) é o documento corporativo que orienta as ações estratégicas da empresa, bem como as ações prioritárias de pesquisa, definindo a missão, a visão de futuro e os valores empresariais, como ainda os objetivos, desafios e diretrizes estratégicas para um período de médio e longo prazo. O documento é construído a partir de uma análise prospectiva sobre tendências, cenários e suas implicações para a agricultura brasileira e para a Embrapa, partindo de discussões que contam com representantes da empresa, das organizações integrantes do Sistema Nacional de Pesquisa Agropecuária (SNPA) e de entidades representativas da sociedade. O Plano Diretor da Embrapa é corporativo e funciona como base para que as Unidades, tanto de pesquisa, quanto de serviço, elaborem, para o mesmo período, seus próprios planos diretores (Plano Diretor da Unidade - PDU).

$\mathrm{O}$ último PDE, quinto elaborado pela instituição, tem como vigência o período de 2008 - 2023 e está estruturado da seguinte forma: apresentação, assinada pelo presidente da Embrapa; introdução; análise prospectiva - explicitando tendências, cenários e implicações, tanto para a agricultura brasileira, quanto para a Embrapa; e estratégias de longo e médio prazo.

No documento são apresentados os desafios que serão enfrentados pela empresa, tanto no âmbito científico e tecnológico (referentes às atividades-fim da empresa), quanto no âmbito organizacional e institucional (referentes às atividades-meio).

Incluída entre os desafios institucionais, a transferência de tecnologia é contextualizada a partir de diretrizes de médio e longo prazo, integrando uma estratégia que busca promover arranjos institucionais e metodologias inovadoras, visando acelerar o processo de transferência/adoção dos conhecimentos e das tecnologias geradas.

Assim, verificamos que o documento trata a transferência de tecnologia como um tema importante da agenda da Embrapa, o que, de certa forma, a fortalece dentro da instituição, tendo em vista que ações de transferência de tecnologia figuram entre as estratégias prioritárias que são descritas como: 
Fortalecer a agenda de transferência de tecnologia da Embrapa (regionais e nacional), sua interação em rede com outras instituições e Organizações Não Governamentais - ONGs e o atendimento às políticas públicas; melhorar a articulação entre Unidades da Embrapa para o cumprimento das agendas de desenvolvimento, transferência de conhecimento e tecnologia; Promover a conectividade com redes sociais para o desenvolvimento, o intercâmbio de conhecimento e a transferência de tecnologia (EMBRAPA, 2008, p.39).

No documento, a empresa assume a transferência de tecnologia como parte de sua missão, descrita como "Viabilizar soluções de pesquisa, desenvolvimento e inovação para a sustentabilidade da agricultura em benefício da sociedade brasileira", quando faz referência a ela em um fragmento do texto explicativo, como segue:

Viabilizar soluções de pesquisa, desenvolvimento e inovação (grifo do autor), entendidas como a introdução de novidade ou aperfeiçoamento no ambiente produtivo ou social, que resultem em novos produtos, processos ou serviços. A transferência de tecnologia faz parte do processo de inovação, o que confere aplicabilidade efetiva às tecnologias geradas (EMBRAPA, 2008, p. 18).

Entre os valores que devem balizar as práticas e comportamentos da Embrapa está a responsabilidade socioambiental, que no documento se materializa através da indicação de que um dos seus princípios é contribuir com conhecimentos e tecnologias para a redução da pobreza e das desigualdades regionais. Assim, podemos dizer que a Embrapa vem se colocando como uma empresa preocupada em desenvolver tecnologias para segmentos que possam estar à margem do desenvolvimento.

Ao tratar diretamente da relação da Embrapa com a agricultura familiar, acreditamos que o conteúdo do documento sinaliza uma tendência crescente da atuação da instituição junto a esse segmento, visto que no V PDE é apresentado como benefício para o público-alvo a "inserção social e econômica da agricultura familiar, das comunidades tradicionais e dos pequenos e médios empreendimentos" (EMBRAPA, 2008).

Ainda consta claramente no Plano a adoção de estratégias a longo e médio prazos para fomentar o desenvolvimento de conhecimentos e tecnologias que contribuam para a inserção social, econômica e produtiva da agricultura familiar, das comunidades tradicionais e dos pequenos empreendimentos, tendo como objetivos intensificar a geração de tecnologias para o uso sustentável dos biomas, a integração 
produtiva das regiões brasileiras e garantir a competitividade e a sustentabilidade da agricultura brasileira.

Entendemos que a comunicação ocupa uma posição estratégica na versão mais recente do planejamento da Embrapa. Propondo "fortalecer a comunicação institucional e mercadológica para atuar estrategicamente diante dos desafios da sociedade da informação", ela aparece com o papel de aprimorar fluxos, canais e espaços formais e informais de diálogo e de influência recíproca entre a Empresa e seus públicos de interesse, tendo como ações prioritárias:

\footnotetext{
Monitorar sistematicamente o ambiente interno, a imagem e as percepções públicas sobre temas estratégicos da Embrapa, de modo que isso contribua para sua sustentabilidade institucional; aprimorar a sintonia entre os focos institucional e mercadológico, por meio da comunicação (EMBRAPA, 2008, p. 44).
}

A análise dos documentos oficiais da instituição nos oferece indícios de que existe, de fato, uma preocupação em criar um espaço de diálogo com os seus públicos, entendendo a comunicação como um elemento que colabora para a sustentabilidade institucional da Embrapa perante a sociedade e diante de seu próprio quadro funcional. Também fica clara a relação direta entre a comunicação institucional e a mercadológica, que abarca a comunicação para transferência de tecnologia, e o interesse da instituição em aprimorar a sintonia entre os focos mercadológico e institucional de suas ações. 


\section{PERSPECTIVAS METODOLÓGICAS}

\subsection{Dados objetivos do trabalho}

\section{$\checkmark$ Objeto de Estudo}

No contexto apresentado no capítulo anterior, fica clara a importância para o país da agricultura familiar, que além de estar pautada na agenda governamental, também exerce um papel expressivo na produção de alimentos, como também da Embrapa, enquanto empresa pública que gera tecnologias capazes de promover mudanças sociais e econômicas em segmentos rurais. É no universo onde os atores, Embrapa e agricultores familiares, se relacionam que o objeto de estudo deste trabalho se constrói, especificamente no que se refere à política de comunicação da Embrapa aplicada à transferência de tecnologia para a agricultura familiar.

\section{$\checkmark$ Problema da Pesquisa}

O problema que impulsiona e orienta esta investigação emerge, primordialmente, da relação entre a Embrapa e a agricultura familiar e se configura, particularmente, por meio de três ações básicas. A primeira é verificar se existe uma ação organizada e articulada de repasse de tecnologias geradas pela instituição e que podem ser disponibilizadas para esse segmento específico de agricultores. A segunda é analisar de que forma está ocorrendo esse processo e de que forma a comunicação tem sido utilizada na transferência de tecnologia. E a terceira envolve investigar o que os atores envolvidos nesse processo - agricultores familiares, extensionistas rurais e empregados da Embrapa - pensam da transferência de tecnologia para a agricultura familiar. A imersão nesse universo se dá por intermédio da formulação de quatro indagações que fundamentaram o caminho percorrido pelo trabalho:

1) A Embrapa possui, de fato, uma política articulada para promover a transferência de tecnologia para a agricultura familiar? 
2) Existe uma estratégia estabelecida pela Embrapa para o uso da comunicação como um recurso potencializador do processo de transferência de tecnologia para a agricultura familiar?

3) Como agricultores familiares e extensionistas rurais veem e avaliam a execução, ou não, por parte da Embrapa, de ações de transferência de tecnologia no contexto agrícola brasileiro?

4) Como os funcionários da Embrapa envolvidos nessas ações avaliam a atuação da empresa, particularmente no que concerne ao uso da comunicação no processo de transferência de tecnologia para a agricultura familiar?

\section{$\checkmark$ Pressuposto}

O conhecimento prévio dos dados que compõem o Relatório da Pesquisa de Imagem, realizada pela Embrapa no período de 2011/2012, nos permitiu partir do seguinte pressuposto: a Embrapa, que tem os agricultores familiares como um de seus públicos e que segue uma linha de atuação pautada nas políticas de desenvolvimento rural do governo federal, não vem atuando de forma satisfatória ao utilizar a comunicação no processo de transferência de tecnologia para este segmento, devido à adoção de um conjunto de medidas que não atende ou não está adequado às necessidades desse público.

\section{$\checkmark$ Objetivo Geral}

Analisar a política da Embrapa com relação à comunicação aplicada ao processo de transferência de tecnologia para a agricultura familiar, verificando o que é proposto pela instituição e o que os atores, que fazem parte desse processo, pensam e como se manifestam com relação a essa conjuntura.

\section{$\checkmark$ Objetivos Específicos}

- Conhecer a relação entre os atores - Embrapa, Ater, técnicos dessas instituições ligados às áreas de comunicação e transferência de tecnologia, e agricultores familiares 
- e de que maneira os seus interesses interferem na política de comunicação para a transferência de tecnologia adotada pela Embrapa;

- Entender o papel da área de comunicação no processo de transferência de tecnologia que é realizado pela empresa;

- Identificar os possíveis entraves na comunicação entre a Embrapa e os agricultores familiares e a percepção desses acerca da instituição e de suas ações.

\section{$\checkmark$ O Lócus}

O universo desta investigação é imenso, uma vez que o ambiente rural e a agricultura familiar estão presentes em todos os estados brasileiros, como também a ação dos atores envolvidos no processo estudado. Dessa forma, sempre soubemos da impossibilidade de se fazer uma pesquisa em âmbito nacional, principalmente pela dimensão continental do país. Assim, foram definidos como local da pesquisa dois estados, Goiás e Rio Grande do Sul, acrescido o Distrito Federal.

A opção pelo estado de Goiás foi de ordem prática, pois levamos em consideração o fácil acesso aos entrevistados decorrente da proximidade com o local de residência da pesquisadora. Quanto à escolha do Rio Grande do Sul, foi levado em conta a característica agrícola do estado, que tem uma forte base na agricultura familiar, já que Canguçu, uma das cidades onde foram realizadas entrevistas, é considerada o maior minifúndio da América Latina.

A partir do conhecimento prévio acerca da existência de diferentes características entre os estados, tais como cultura, posicionamento da extensão rural, políticas agrícolas estaduais, foi considerado também que realizar a pesquisa em ambos os estados poderia ajudar a perceber nuances de proximidade ou antagonismo na forma de os atores verem ou se relacionar com o objeto estudado.

As cidades onde foram realizadas as entrevistas foram:

Rio Grande do Sul - Arroio do Padre; Canguçu (maior minifúndio do Brasil); Morro Redondo; Rio Grande; São Lourenço; e Pelotas.

Goiás - Formosa; Luziânia; Planaltina de Goiás; Valparaíso de Goiás; Goianira; Santo Antônio; Nova Veneza; e Brazabrantes. 


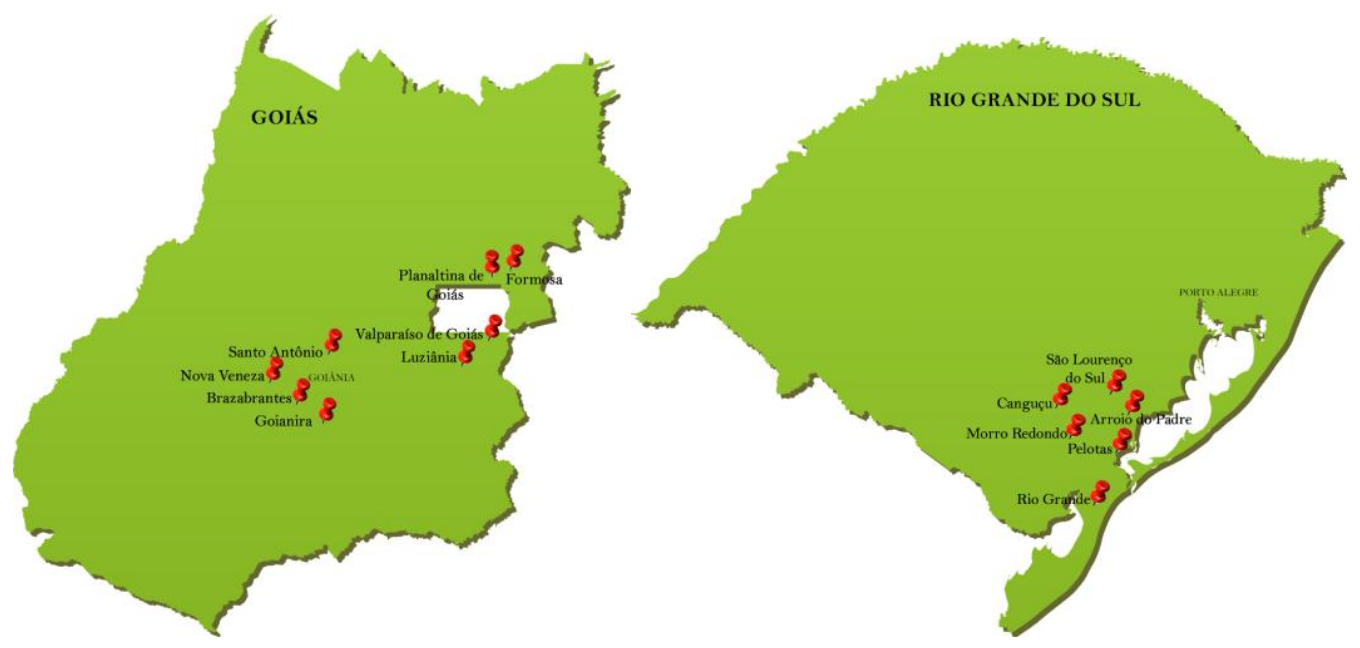

Figura 1: Locais das entrevistas

Ainda foram realizadas entrevistas com empregados da Embrapa no Distrito Federal, local onde está situada a Sede da instituição.

\section{$\checkmark$ O Corpus}

O corpus desta pesquisa compreende o conjunto das falas dos atores - Embrapa, extensão rural e agricultores familiares - envolvidos no processo estudado.

A relação estabelecida entre esses atores e o objeto de estudo está constituída da seguinte forma: os entrevistados da Embrapa estão relacionados, de forma direta ou indireta, e em diferentes âmbitos, com os processos de elaboração e execução das ações de transferência de tecnologia da instituição. Já os técnicos de extensão rural ocupam o papel de intermediários entre a Embrapa e os agricultores, sendo, muitas vezes, os responsáveis por transferir a tecnologia gerada pela Embrapa para o usuário final, que, neste caso específico, são os agricultores familiares.

Foram ouvidos 68 agricultores familiares (34 em cada estado), 11 gestores e técnicos das áreas de comunicação e transferência de tecnologia da Embrapa (cinco com atuação coorporativa e seis atuando em Unidades de pesquisa/serviço) e 11 técnicos das empresas estaduais de assistência técnica e extensão rural (cinco do Rio Grande do Sul e seis de Goiás). 


\subsection{Abordagem teórico-metodológica, método de análise e técnicas de coleta de dados}

\subsubsection{O método dialético como abordagem teórico-metodológica}

Com relação à abordagem teórico-metodológica, selecionamos para análise da pesquisa o método dialético, tendo como base três parâmetros acerca do objeto de pesquisa: ele é dinâmico, altera-se e gera conflito. Também, pautamo-nos no pensamento de Demo (1995), segundo o qual a metodologia dialética é a mais conveniente para o estudo da realidade social, que deve ser tratada por métodos que englobem seu lado da consciência reflexa, da ideologia e da qualidade política. Ao defender a dialética para tratar fenômenos sociais históricos, o autor toma como pressuposto que toda formação social é suficientemente contraditória, tendo dentro de si condições para o aparecimento de uma nova fase, estando, assim, sempre em transição.

A dialética consegue situar o objeto no universo da pesquisa, visto que existem, nesse caso, diferentes parâmetros de ver o mundo, representados por três atores: Embrapa, Ater e agricultores familiares. Esses atores estabelecem uma relação dinâmica, por vezes conflituosa e que também se altera. Assim, consideramos que esse método "fornece as bases para uma interpretação dinâmica e totalizante de realidade, já que estabelece que os fatos sociais não podem ser entendidos isoladamente, abstraídos de suas influências políticas, econômicas, culturais etc.” (GIL, 2010, p.14).

O método dialético reconhece a dificuldade de se apreender o real, em sua determinação objetiva, por isso a realidade se constrói diante do pesquisador por meio das noções de totalidade, mudança e contradição. A noção de totalidade refere-se ao entendimento de que a realidade está totalmente interdependente, inter-relacionada com os fatos e com os fenômenos que a constitui (DINIZ, 2008).

Assim, é com um olhar dialético que será analisado e interpretado o universo da pesquisa, uma vez que percebemos um conflito no cerne da questão que envolve este trabalho, que analisa um universo permeado por relações de competição, jogos de poder, interesses políticos e por ideias que convivem e que, algumas vezes, chocam-se entre si.

A maneira de observar a realidade da qual fazem parte a Embrapa, a Ater e os agricultores familiares será ancorada na dialética, entendendo que essa é a perspectiva 
que poderá estabelecer parâmetros capazes de compreender os elementos que compõem o fenômeno estudado, como ainda a forma como ele se caracteriza e se processa.

\subsubsection{A análise de conteúdo e a análise documental}

Quanto ao método de análise, utilizamos a análise de conteúdo para interpretação dos dados levantados nas entrevistas, que segundo Bardin (1977, p.36), tomando como referência a definição de Berelson, é "uma técnica de investigação que através de uma descrição objetiva, sistemática e quantitativa do manifesto das comunicações, tem por finalidade a interpretação dessas mesmas comunicações".

A análise de conteúdo é um método empírico que se adapta ao tipo de "fala" que se está analisando e ao tipo de interpretação que se pretende como objetivo, sendo que qualquer comunicação, sob o aspecto de transporte de significações de um emissor para um receptor, controlada ou não por este, pode ser decifrada por essa forma de análise (BARDIN, 1977).

De acordo com Freitas e Janissek (2000), a análise de conteúdo tem como objetivo a inferência de conhecimentos e permite, no caso de entrevistas, avaliar as opiniões dos respondentes, observando a sua satisfação e insatisfação, não se restringindo apenas a termos expressos, mas também ao que ficou subentendido no discurso analisado.

Dentro do método de análise de conteúdo, foi utilizada a análise categorial, que funciona por operações de desmembramento do texto em unidades, ou seja, em categorias. A categorização é uma espécie de gaveta ou rubrica significativa que permite a classificação dos elementos de significação constitutivas da mensagem (BARDIN, 1977).

Para a interpretação dos dados levantados a partir de documentos institucionais da Embrapa, foi utilizado o método de análise documental, que, conforme sua própria designação, compreende a identificação, a verificação e a apreciação de documentos.

Neste trabalho, a análise documental foi utilizada como método e também como técnica, pois de acordo com Moreira (2011, p. 272), no caso da pesquisa científica, a análise documental é ao mesmo tempo método e técnica. "Método porque pressupõe o ângulo escolhido como base de uma investigação. Técnica porque é um recurso que complementa outras formas de obtenção de dados, como a entrevista e o questionário". 


\subsubsection{O uso da entrevista em profundidade como técnica de coleta de dados}

$\mathrm{Na}$ pesquisa de campo, foram realizadas entrevistas individuais em profundidade com todos os atores envolvidos no processo estudado. Segundo Duarte (2011), essa é uma técnica qualitativa que explora um assunto a partir da busca de informações, experiências e percepções dos informantes. Para o autor, entre as principais qualidades dessa abordagem está a flexibilidade de "permitir ao informante definir os termos da resposta e ao entrevistador ajustar livremente as perguntas" (DUARTE, 2011, p. 62).

O uso da técnica de entrevistas permitiu a identificação das diferentes maneiras de perceber e descrever o fenômeno estudado.

As entrevistas tiveram caráter semiaberto, com a utilização de um roteiro que funcionou como uma matriz de cobertura para os interesses da pesquisa. A entrevista semiaberta "parte de certos questionamentos básicos, apoiados em teorias e hipóteses que interessam à pesquisa, e que, em seguida, oferecem amplo campo de interrogativas, fruto de novas hipóteses que vão surgindo à medida que se recebem as respostas do informante" (TRIVIÑOS, 1990, p. 146).

\subsection{Ações práticas do trabalho}

\subsubsection{Pesquisa bibliográfica}

Um dos primeiros passos para elaborar este trabalho foi uma pesquisa bibliográfica para buscar identificar e compreender os conceitos subjacentes às questões da agricultura familiar, como também o panorama histórico do segmento e também da Embrapa. De início, foram levantadas informações que permitem entender o contexto que envolve a instituição e os agricultores familiares, como também o cenário em que estão inseridos. Já na fase seguinte, foram buscadas teorias e informações acerca da comunicação para o desenvolvimento, eixo central do trabalho, como ainda conceitos que dialogam com o objeto estudado. 


\subsubsection{Análise documental}

Em um segundo momento, realizamos uma análise documental da Política de Comunicação da Embrapa, publicada em 2002, bem como da versão anterior, de 1996, visando conhecer e comparar as versões, verificando suas diferenças e identificando como a comunicação é apresentada hoje e qual o papel que ela ocupa na Embrapa, bem como em que contextos são abordados os temas transferência de tecnologia e agricultura familiar. Seguindo a mesma linha de análise, também foi realizada a leitura do Plano Diretor da Embrapa - PDE (2008 -2023), que explicita o direcionamento estratégico da instituição para os próximos anos, e uma proposta do Departamento de Transferência de Tecnologia para um Marco Referencial de Transferência de Tecnologia, Intercâmbio e Construção do Conhecimento, que tem como princípio subsidiar a integração entre macroprocessos institucionais e orientar a interação entre a Embrapa e a sociedade.

Anteriormente à análise dos documentos citados, também foi realizada na fase inicial deste trabalho uma análise dos resultados quantitativos e qualitativos da pesquisa de imagem institucional, que foram de grande importância na constituição do pressuposto deste estudo e também na construção do objeto, deixando clara a existência de um problema possível de ser estudado. Esse processo permitiu uma investigação direta, por meio do estudo de documentos que contextualizavam o objeto, possibilitando encontrar indícios para compreender a realidade.

\subsubsection{Pesquisa exploratória}

Buscando uma maior aproximação com o universo da pesquisa e o levantamento de possibilidades que contribuíssem na estruturação do trabalho, realizamos uma pesquisa exploratória com 23 agricultores familiares do Distrito Federal.

Por meio de entrevistas semiestruturadas, foram ouvidos agricultores familiares em cinco núcleos rurais. A amostra procurou assegurar a representatividade de diferentes localidades rurais do Distrito Federal, que foram indicadas por um articulador de Extensão Rural da Emater do Distrito Federal. Os agricultores familiares foram indicados pelos representantes dos escritórios da Emater de cada núcleo rural pesquisado, atendendo a diferentes perfis, desde empreendedores mais capitalizados até agricultores com pouco excedente para comercialização. Foram ouvidos agricultores 
familiares dos núcleos rurais: Tabatinga (cinco entrevistados), Jardim (cinco entrevistados), Rio Preto (dois entrevistados ${ }^{20}$ ), Alexandre Gusmão (seis entrevistados) e Ceilândia (cinco entrevistados).

Os resultados obtidos com as entrevistas foram de grande importância no apontamento de caminhos a serem seguidos, principalmente ao identificar e indicar situações que contribuíram para o estabelecimento de uma proposta base de categorias de análise para nortear a pesquisa de campo.

\subsubsection{Pesquisa de campo}

A partir das etapas anteriores, foram realizadas, de abril a novembro de 2014, entrevistas em profundidade com os atores do processo estudado. As entrevistas aconteceram durante o período de junho a novembro de 2015. A escolha dos entrevistados foi realizada da seguinte forma:

- Os entrevistados da Embrapa foram escolhidos por ocuparem cargos ou desenvolverem atividades diretamente ligadas às áreas de transferência de tecnologia ou de comunicação da empresa.

- Os técnicos de extensão rural foram escolhidos de forma aleatória, de acordo com as localidades onde foram realizadas as entrevistas com os agricultores e também pela disponibilidade do técnico para ser entrevistado.

- Os agricultores foram indicados por técnicos da Emater dos municípios, sendo que estes foram determinados pela gerência regional da Emater de cada estado.

\section{$\checkmark$ Constituição e caracterização da amostra}

a) Grupo 1 - Agricultores familiares

b) Grupo 2 - Agentes de extensão rural

c) Grupo 3 - Embrapa

\footnotetext{
${ }^{20}$ No núcleo rural de Rio Preto foram realizadas apenas duas entrevistas por causa do não agendamento, pelo representante do escritório da Emater dessa localidade, das outras entrevistas.
} 


\section{Grupo 1 - Agricultores Familiares}

Foram realizadas entrevistas presenciais com 34 agricultores familiares do Rio Grande do Sul e 34 de Goiás, totalizando 68 agricultores entrevistados. A amostra procurou assegurar a maior representatividade possível de diferentes localidades rurais de ambos os estados, que foram indicadas pelos representantes estaduais e regionais do órgão de extensão rural pública, Emater Rio Grande do Sul e Emater Goiás.

Todos os agricultores familiares foram indicados pelos representantes dos escritórios locais de extensão rural, e o único critério estabelecido foi que se observasse a orientação $\mathrm{FAO} /$ Incra, que define o universo familiar como aquele integrado pelos estabelecimentos que atendem, simultaneamente, às seguintes condições: direção dos trabalhos do estabelecimento exercida pelo produtor; trabalho familiar superior ao trabalho contratado e estabelecimentos com área não superior à máxima regional, estabelecida em 15 módulos fiscais.

Foram entrevistados agricultores com idades entre 20 e 76 anos, mas a faixa etária em que está localizado o maior número de agricultores pesquisados é de 56 a 65 anos, estando nessa faixa $41 \%$ dos entrevistados de Goiás e $32 \%$ dos entrevistados do Rio Grande do Sul. Quanto ao nível de escolaridade, a maioria, em ambos os estados, não concluiu o ensino fundamental, representando $58 \%$ dos entrevistados de Goiás e $67 \%$ dos entrevistados do Rio Grande do Sul. Salienta-se que no estado de Goiás a maioria dos entrevistados produz hortaliças, 53\%, enquanto no Rio Grande do Sul predomina na amostra produtores de leite, $41 \%$.

Neste trabalho os agricultores familiares serão identificados por números de um a 34, seguidos do estado de que fazem parte.

\section{$\underline{\text { Grupo } 2 \text { - Agentes de Extensão Rural }}^{21}$}

\footnotetext{
${ }^{21}$ Mesmo não tendo uma relação direta com o trabalho que está sendo realizado, é importante apresentar um breve panorama sobre a situação da extensão rural pública em ambos os estados pesquisados, pois existem fatores que podem influenciar na percepção ou na ação dos atores acerca do objeto de estudo. As informações que serão apresentadas a seguir foram levantadas junto aos extensionistas, tanto da Emater do Rio Grande do Sul, quanto de Goiás. No Rio Grande do Sul, encontrou-se uma Emater um pouco mais fortalecida, que, segundo um dos extensionistas entrevistados, recebeu incentivos do governo do estado, começando pela contratação de novos técnicos, e que teve também acesso a recursos oriundos de chamadas públicas do Ministério do Desenvolvimento Agrário (MDA) para o desenvolvimento de projetos na região. Mas, além dessa Emater que parece revitalizada, também foi encontrada uma instituição que vive assombrada pela possibilidade de perder o caráter de empresa filantrópica, que a isenta de recolher impostos federais, e, por consequência de fechar as portas. De acordo com uma matéria publicada no jornal Zero Hora, há dois anos o Ministério Público Federal ingressou na Justiça com um
} 
Foram entrevistados cinco agentes de extensão rural no Rio Grande do Sul e seis em Goiás. Todos os entrevistados foram escolhidos de forma aleatória. Alguns possuíam funções gerenciais e outros eram extensionistas rurais de atuação em campo.

No capítulo de análise, os entrevistados serão indicados pelas letras A, B, C, D, E e F seguida do estado de que fazem parte.

\section{Grupo 3 - Embrapa}

Na Embrapa foram entrevistadas 11 pessoas que possuem relação direta com as áreas de comunicação e de transferência de tecnologia realizada pela instituição, sendo cinco atuando na Sede e seis em Unidades. Todos os entrevistados possuem funções gerenciais e as entrevistas foram presenciais e realizadas em Brasília, Pelotas e Goiânia.

Visando preservar o anonimato dos entrevistados, esses são identificados neste trabalho por um código alfanumérico, com uma identificação de local e área de atuação, seguida por um número. Assim, o local de atuação é identificado como Sede ou UD (Unidades) e as áreas de atuação como Com (comunicação) e TT (transferência de tecnologia). Os números, que foram determinados aleatoriamente, servem para diferenciar uma Unidade da outra, como também os entrevistados.

Mesmo com a existência de um roteiro, em algumas entrevistas foram identificados momentos que exigiram a realização de perguntas adicionais para que fosse possível explicar questões que não ficaram claras, ou por entender que outras informações poderiam contribuir para estruturar o contexto do objeto de pesquisa.

recurso contra a Emater pedindo a suspensão da liminar que garante a filantropia à instituição, o que a levaria a ter que pagar à União o passivo de $\mathrm{R} \$ 2$ bilhões referente a contribuições de seguridade social. Já em Goiás, foi encontrada uma Emater totalmente sem estrutura, tanto de pessoal quanto financeira. Constatou-se que em alguns lugares existia apenas um extensionista para atender um município inteiro, sem contar com recursos básicos para trabalhar. De acordo com um dos entrevistados, o governo do estado só se responsabiliza pelo pagamento dos salários, tendo que cada técnico arrecadar receitas a partir de trabalhos prestados aos agricultores para poder manter os escritórios funcionando. Alguns escritórios estão em melhores condições porque contam com o apoio das prefeituras, mas, nesse caso, estão à mercê do interesse político de estar voltado, ou não, para a questão da extensão rural. 


\subsection{Definição das categorias de análise}

A partir do conjunto de ações já apresentado, e com base nas indicações encontradas quando da realização da pesquisa exploratória, chegamos ao processo de constituição das categorias de análise.

Segundo Duarte (2011, p.79), as categorias de análise são “estruturas construídas pelo pesquisador que reúnem e organizam o conjunto de informações obtidas a partir do fracionamento e da classificação em temas autônomos, mas inter-realcionados". Em cada categoria, o pesquisador aborda determinadas respostas dos entrevistados, descrevendo, analisando e citando frases colhidas durante o processo de entrevista, tornando-a um conjunto articulado e autônomo.

Neste trabalho, para uma melhor compreensão e análise dos dados, foram definidas três grandes categorias, intituladas a partir da visão de cada ator envolvido no processo. As categorias foram definidas como: a visão dos extenionistas, a visão dos agricultores familiares e a visão da Embrapa - por meio dos empregados/gestores da instituição. Para que fosse possível entender o processo como um todo e suas especificidades, a partir dessas categorias maiores foram criadas subcategorias, conforme apresentado no quadro abaixo:

\begin{tabular}{|c|c|c|}
\hline CATEGORIA & & \multicolumn{1}{|c|}{ SUBCATEGORIA } \\
\hline & a) & $\begin{array}{l}\text { Desenvolvimento de tecnologias pela Embrapa para a } \\
\text { agricultura familiar }\end{array}$ \\
$\begin{array}{l}\text { 1) Visão dos } \\
\text { Familiares }\end{array}$ & b) & $\begin{array}{l}\text { Conhecimento e percepção acerca da Embrapa } \\
\text { c) }\end{array}$ \\
& d) & $\begin{array}{l}\text { Recepção de informações e conhecimento de veículos } \\
\text { de comunicação da Embrapa }\end{array}$ \\
\hline
\end{tabular}




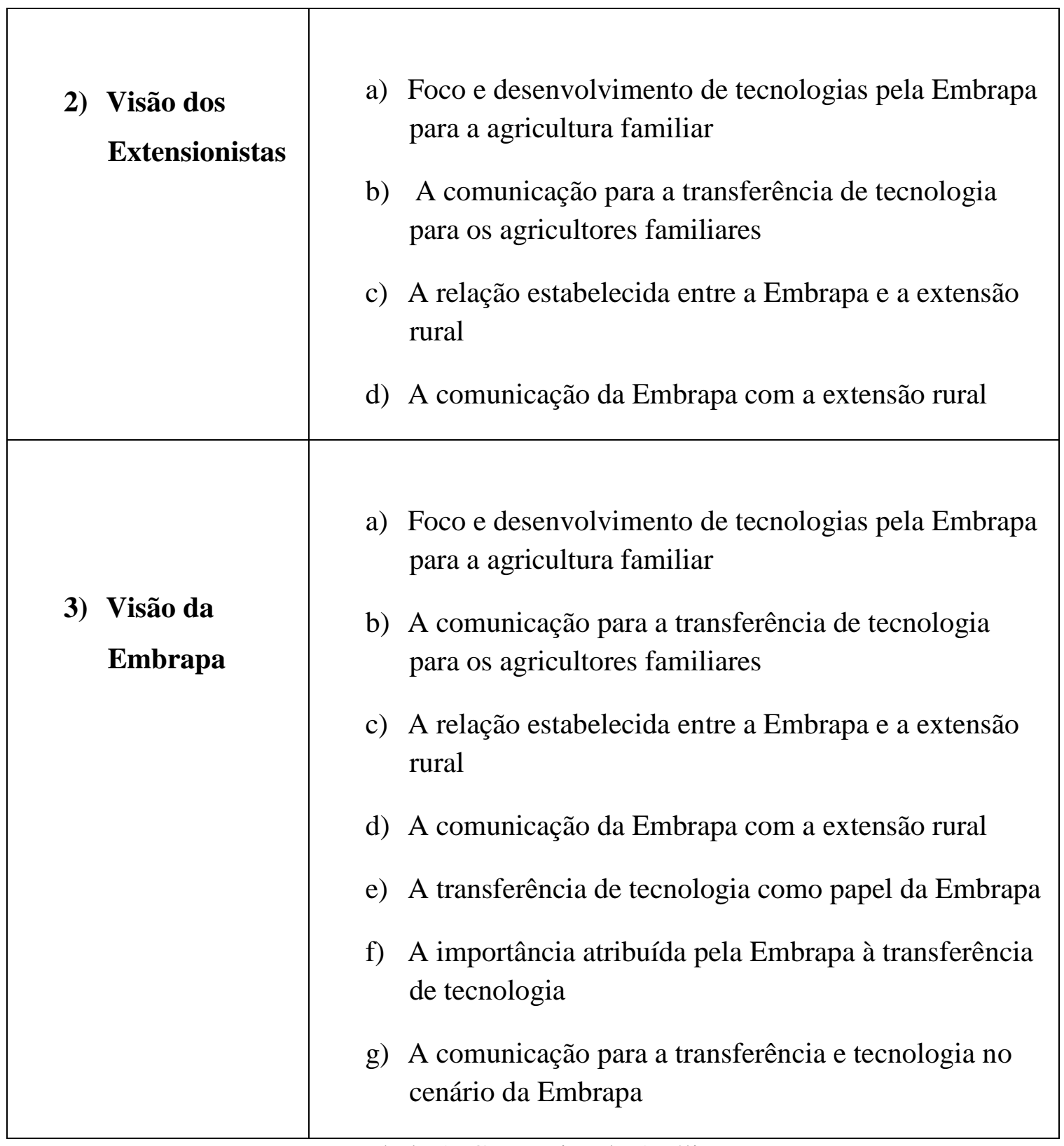

Tabela 1: Categorias de Análise 


\section{A COMUnicaÇÃo PARA O DESENVOLVIMENTO COMO PONTO DE REFLEXÃO E OUTRAS PERSPECTIVAS CONCEITUAIS}

O fenômeno estudado neste trabalho, que envolve a política de comunicação da Embrapa aplicada à transferência de tecnologia para a agricultura familiar, é relacional e apresenta características que mesclam o rural, o tecnológico, a comunicação, as políticas públicas e o desenvolvimento, como fatores de mudança social e econômica. Assim, buscando uma melhor compreensão do objeto pesquisado, é necessário dialogar com um conjunto de conceitos que ajuda a refletir sobre as dimensões, as consequências e os significados envolvidos nesse fenômeno.

Dessa forma, nesse contexto de ação e estudo, que sinaliza a possibilidade de mudança social e econômica de um segmento de agricultores a partir do conhecimento de tecnologias geradas por uma empresa pública de pesquisa, tomamos como principal referência conceitual para a nossa reflexão a comunicação para o desenvolvimento, principalmente porque entendemos que a comunicação que tem como base esse enfoque pode ter um papel estratégico no processo de mudança social, que, por sua vez, está imbricado no conceito do próprio desenvolvimento. Ainda dentro do universo da comunicação, iremos abordar as políticas públicas de comunicação relacionadas ao desenvolvimento rural no Brasil, usando como referência estudos da professora Maria Salett Tauk Santos. Como pano de fundo, trazemos também neste capítulo uma contextualização sobre a ideia do desenvolvimento em si, o seu surgimento, a evolução conceitual e as proposições do indiano Amartya Sen, que apresenta uma mudança inovadora e determinante na forma de entender essa questão.

Por fim, serão expostos conceitos diretamente ligados ao universo deste trabalho. Os conceitos de transferência de tecnologia e de política serão apresentados por representarem elementos que constituem o próprio objeto de estudo, ao passo que os de tecnologia agrícola e informação tecnológica, por serem complementares para o entendimento do processo como um todo.

\subsection{A Comunicação para o Desenvolvimento}

O conceito de desenvolvimento, com marcante viés econômico, começa a se desenhar num período em que os setores primário, industrial e comercial passam por 
fragilidades próprias do momento histórico vivido pelo mundo no período pós-Segunda Guerra. Assim, com foco desenvolvimentista, parte dos Estados Unidos a iniciativa de criar um programa internacional de assistência técnica e financeira para o desenvolvimento de países aliados, criando para isso a Agência dos Estados Unidos da América para o Desenvolvimento Internacional, a Usaid (BELTRÁN, 2005). Dentro dessa estratégia, foram estabelecidos serviços cooperativos com governos de vários países, inclusive latino-americanos, nas áreas de agricultura, saúde e educação. Assim, entendendo que a ação para o desenvolvimento nesses campos requereria provocar, por meio de persuasão educativa, mudanças de conduta, tanto dos funcionários dos governos quanto dos beneficiários dos serviços, foi criada para cada uma das áreas uma unidade de comunicação que apoiaria as atividades de extensão rural, educação sanitária e educação audiovisual. A ação dessas unidades de comunicação, constituídas com finalidade cooperativa, foi então um pilar do que mais tarde seria chamado de “comunicação para o desenvolvimento" (BELTRÁN, 2005, p.5).

Segundo Beltrán (2005), o início da teorização voltada à comunicação para o desenvolvimento aconteceu nos Estados Unidos aproximadamente dez anos após o começo de sua prática, quando o sociólogo Daniel Lerner, em 1958, publica um estudo realizado com dados de cinquenta países, que abandonavam a "sociedade tradicional" para irem em direção à "modernização", em que apontava a existência clara e estreita entre o desenvolvimento e a comunicação, sendo que essa era, ao mesmo tempo, “indutora e indicadora de mudança social” (BELTRÁN, 2005, p.9).

Já em 1962, é a vez do sociólogo rural Everett Rogers se tornar figura proeminente ao publicar o livro The Diffusion of Innovation, apresentando sua teoria da difusão de inovações como motivador da modernização, em que a comunicação seria utilizada como ferramenta de persuasão para adoção de tecnologias. Especialistas da sociologia da comunicação rural de vários países em desenvolvimento criticaram a teoria difusionista de Rogers por ignorar as hierarquias e as relações de forças em sociedades profundamente segregadas, nas quais a decisão de aceitar ou rejeitar a ideia de inovação e a definição do formador de opinião estão condicionadas aos mecanismos de poder (MATTELART, 2011).

O paradigma difusionista, inaugurado por Rogers, influencia até hoje ações na área agrícola, e, de forma mais específica, os processos de extensão rural e transferência de tecnologia, em que comumente os agricultores são vistos como usuários que 
precisam ser convencidos acerca dos "benefícios" das tecnologias, que muitas vezes são geradas "para" eles sem, necessariamente, a observação de uma demanda.

Em 1964, com o apoio da Unesco, Wilbor Scharamm publica o livro Mass Media and National Development, tornando-se referência universal em comunicação para o desenvolvimento. O livro de Scharamm, juntamente com o trabalho de outros pesquisadores ligados ao respeitado Massachussets Institute of Technology (MIT), como Daniel Lerner, acabou se transformando na base teórica da comunicação para o desenvolvimento, difundindo a crença de que os meios de comunicação de massa eram capazes de contribuir para que o terceiro mundo fizesse em décadas o que os países desenvolvidos haviam feito em séculos: "passar de um tradicionalismo atrasado para uma próspera modernidade" (BELTRÁN, 1993, p.2).

Segundo Beltrán (1993), em pouco tempo as teorias propostas pelos pesquisadores estadunidenses foram adotadas por inúmeros especialistas latinoamericanos em comunicação para o desenvolvimento, mais fortemente no final da década de 1960, com a chegada à América latina do modelo difusionista proposto por Rogers.

A prática da comunicação para o desenvolvimento, de acordo com o formato operativo proposto pelos pesquisadores estadunidenses, foi compartilhada pelos organismos internacionais de financiamento para o desenvolvimento, que na época implantavam centenas de projetos que tinham como foco atender às problemáticas agrícolas, educativas e de saúde de países subdesenvolvidos.

A partir de meados da década de 1960, começam a surgir na academia, tanto na área econômica, quanto social, discussões e críticas acerca do movimento desenvolvimentista, o que levou a uma nova visão sobre o desenvolvimento, induzindo a uma reflexão dos seus processos de mudanças e suas consequências. E é sob essa ótica, que na década de 1970 teóricos latino-americanos iniciam a formulação de um novo modelo de comunicação, rompendo com o paradigma até então adotado, que se fundamentava exclusivamente na transmissão e na persuasão. Nesse contexto se sobressaiu o pensamento dos latino-americanos Paulo Freire, Luis Ramiro Beltrán e Juan Díaz Bordenave, que tomam como referência um modelo de comunicação que busca a mudança social a partir da participação e do diálogo. De acordo com Ponchio (2011), os argumentos desses autores se complementaram na defesa de que a comunicação deve cumprir papel estratégico para o processo de desenvolvimento, 
baseado na participação popular, funcionando como facilitador de trocas $\mathrm{e}$ aproximações entre as pessoas, de modo a fortalecer o tecido social.

Tanto Paulo Freire quanto Bordenave até hoje são reconhecidos como referências de uma comunicação alternativa àquela que se coloca como um mero difusor de tecnologias e que toma a persuasão como principal direcionamento. Entretanto, a proposta de comunicação de Freire é amplamente discutida na área da comunicação, principalmente por assumir um caráter utópico e filosófico, pautada em temas como solidariedade, amor, humildade, fé e ação libertadora. Mesmo gerando polêmica, é indiscutível a contribuição do teórico para a comunicação voltada para o desenvolvimento, principalmente porque para Freire a comunicação verdadeira não está na exclusiva transferência ou transmissão de conhecimento de um sujeito, "mas em sua co-participação no ato de compreender a significação do significado" (Freire, 1971, p.70).

Bordenave, que muito se dedicou à comunicação para o desenvolvimento rural, segundo Beltrán (2007), tem o mérito de ter sido criativo e ter se empenhado, sistematicamente, para ressaltar a importância de o povo assumir o protagonismo na comunicação, passando também a ser o emissor de suas próprias mensagens. Para Bordenave, o interlocutor também é capaz de gerar e trocar informações e conhecimentos, construindo um poder coletivo capaz de avançar para a transformação social.

Assim, as novas ideias que partiam da América Latina logo fizeram eco nos Estados Unidos, onde foram reconhecidas pelos principais teóricos da comunicação para o desenvolvimento, tanto que, em 1976, Everett Roggers reviu suas convicções, chegando a prever a extinção do paradigma dominante (BELTRÁN, 2005; BELTRÁN, 1993).

Essas reformulações teóricas pouco influenciaram na prática da comunicação de apoio ao desenvolvimento, que seguiu adiante sem grandes mudanças. Mas, em contraste a isso, a prática e a teoria de uma comunicação alternativa para o desenvolvimento democrático foram sustentadas e enriquecidas durante toda a década de 1970, principalmente em virtude de esforços que se multiplicaram por diversas partes da América Latina. No entanto, na segunda metade da década de 1980 a produção intelectual sobre o tema na América Latina decai, mas a discussão é retomada já na década seguinte (BELTRÁN, 2007). 
A década de 1990 foi rica em criativas reflexões sobre o desenvolvimento, período em que se sobressaiu o pensamento da peruana Rosa Maria Alfaro, que publica então uma proposta efetiva de uma comunicação para "um outro desenvolvimento", que o percebia como um fenômeno de relação sociocultural, e não apenas como um instrumento de apoio a programas desenvolvimentistas. E é com essa perspectiva que a comunicação para o desenvolvimento começa a ser entendida como uma comunicação direcionada para a mudança social.

Sob essa perspectiva de mudança social, o espanhol Alejandro Barranquero (2007) identifica que toda ação de desenvolvimento implica em entender que comunicação, como todo processo comunicativo, está ligada a algum tipo de transformação e que a mudança social positiva não aparece de forma imediata ou casual. Para que aconteça uma comunicação de fato, capaz de promover mudanças sociais, "nossas ações têm que estar intencionalmente dirigidas e sistematicamente planejadas" (BARRANQUEIRO, 2007, p. 117, tradução nossa).

Barranquero (2007) apresenta ainda algumas premissas que seriam fundamentais para a realização da comunicação para o desenvolvimento, com o foco na mudança social:

- Na comunicação e na educação para a mudança social interessa mais o processo de transformação coletiva do que os produtos (programas de rádio, spots, vídeos, campanhas etc).

- O processo deve promover o acesso, a participação e a apropriação final de si próprio pelos atores envolvidos.

- Deve contemplar a pertinência cultural das ações que são propostas e que estas se atenham às particularidades de cada cultura.

- Mesmo que em um projeto global, interessa criar um marco de atuação local, baseado no saber comunitário.

- Para evitar o excessivo localismo, é necessário estimular a organização em rede e vincular cada projeto com experiências similares em nível local, regional e global.

- Deve-se usar o meio e a tecnologia apropriada para cada contexto, entendendo-os unicamente como meios e nunca como fins em si mesmos. 
- E, por último, deve-se trabalhar com objetivos a médio e longo prazo, visto que esta é a única forma de se conseguir uma apropriação dos processos por parte da comunidade e uma mudança sustentável e prolongada.

A comunicação voltada para a mudança social privilegia a participação e o diálogo, e é essa a orientação que hoje é adotada pela Organização das Nações Unidas para a Agricultura e Alimentação (FAO/ONU), que usa a expressão "comunicação para o desenvolvimento" - "communication for development" ou "comunicación para el desarrollo" - em seus documentos. O principal objetivo do I Congresso Mundial sobre Comunicação para o Desenvolvimento, realizado pela ONU, em 2006, foi inserir o campo de "comunicação para o desenvolvimento" na agenda de desenvolvimento e cooperação internacional (PONCHIO, 2011).

Na publicação oficial que relata o contexto, objetivos, debates, em parte dos artigos apresentados e recomendações desse Congresso, é amplamente reiterada a importância de que políticas nacionais incluam a comunicação participativa. Diferentemente da interpretação de "comunicação para o desenvolvimento" das décadas anteriores, quando essa se afiliava ao difusionismo e à modernização, agora as Nações Unidas a definem como processo que "permite a comunidades manifestar-se livremente, expressar suas aspirações e preocupações e participar das decisões que dizem respeito ao seu desenvolvimento" (PONCHIO, 2011).

Especificamente com relação à comunicação para o desenvolvimento rural, a FAO (2015) entende que:

A Comunicação para o Desenvolvimento (CPD) é uma chave para impulsionar a agricultura e o desenvolvimento rural. É um processo de comunicação orientada para os resultados com base no diálogo e participação, possibilitando à população rural expressar suas opiniões, compartilhar conhecimento e participar ativamente do seu próprio desenvolvimento. Através de uma ampla gama de métodos e ferramentas, incluindo meios de comunicação locais e TICs, a comunicação para o desenvolvimento pode maximizar o impacto das iniciativas de desenvolvimento, promover o diálogo entre os vários atores, como ainda a tomada de decisão informada e a ação coletiva (Tradução nossa).

A comunicação para o desenvolvimento, com o passar do tempo, foi adotando uma posição com bases sólidas no diálogo e na participação, mas cada vez mais é 
necessário incorporar ao debate teórico acerca do tema os novos desafios do desenvolvimento, especialmente no âmbito da ruralidade, em que são encontradas novas concepções acerca do espaço rural, que combinam atividades agrícolas e não agrícolas no mesmo território agrário, como ainda as noções de desenvolvimento local e sustentabilidade.

Assim, entendemos que a comunicação para o desenvolvimento, da forma como se configura atualmente, pode ser fundamental como uma nova referência na construção do processo de transferência de tecnologia, principalmente por ser estabelecida em bases participativas e dialógicas. O princípio da mudança social, que permeia essa modalidade de comunicação, coloca-a próxima ao objeto de estudo deste trabalho, que é a política de uma empresa pública de pesquisa com relação à transferência de tecnologias para um segmento de agricultores que pode usufruir de mudanças, tanto econômicas quanto sociais, a partir do acesso a elas.

\subsection{Entendendo a questão do desenvolvimento}

$\mathrm{Na}$ linguagem popular, desenvolvimento descreve um processo pelo qual as potencialidades de um objeto ou organismo são liberadas para que esse alcance a sua forma natural, amadurecida e completa, tal como o crescimento de um animal ou uma planta. Na biologia, inicialmente a palavra se referia ao processo pelo qual os organismos atingiam o seu potencial genético, até que entre 1759 (Wolff) e 1859 (Darwin) a ideia do desenvolvimento evoluiu da concepção de transformação para a de aperfeiçoamento. Foi nessa época que cientistas começaram a tratá-lo como sinônimo de evolução (ESTEVA, 2000, p.59).

De acordo com Esteva (2000), a transferência da metáfora biológica para a esfera social aconteceu no final do século XVIII, quando o fundador da história social, Jesus Moser, começa a empregar a palavra desenvolvimento para designar o processo gradual de mudança social.

Mas, segundo Sachs (2008), é na década de 1940, no contexto de preparação dos projetos para a reconstrução da periferia devastada da Europa após a Segunda Guerra Mundial, que surge a reflexão sobre o desenvolvimento, tal como se conhece hoje.

Essa reflexão também foi pautada pela tomada de consciência do atraso econômico em que vivia a grande maioria da humanidade. Indicadores como a 
mortalidade infantil, grau de alfabetização e a incidência de doenças contagiosas, entre outros, passam a ser considerados, contribuindo para solidificar as ideias de desenvolvimento atreladas ao bem-estar-social, a modernização "e a tudo que sugeria acesso às formas de vida criadas pela civilização industrial” (FURTADO, 1980, p.20).

Para Furtado (1980), à época, a reflexão sobre o tema foi alimentada pelo debate político, reflexo das transformações produzidas pela Segunda Guerra, tais como o desmantelamento das estruturas coloniais e o estabelecimento de novas formas de hegemonia internacional, fundadas no controle tecnológico, na informação e na manipulação ideológica.

Nesse período, o conceito de desenvolvimento estava fortemente ligado a um viés econômico, fazendo com que até o início dos anos 1960 não se sentisse a necessidade de distinguir desenvolvimento de crescimento econômico, uma vez que as poucas nações desenvolvidas eram as que haviam se tornado ricas pela industrialização, enquanto os países que permaneciam subdesenvolvidos eram os pobres, com um processo de industrialização incipiente ou que nem sequer existia (VEIGA, 2008, p.18).

Todavia, de acordo com José Eli da Veiga, foram surgindo evidências de que o forte crescimento econômico na década de 1950 em diversos países semiindustrializados, entre os quais o Brasil, não era sinônimo de maior acesso de populações pobres a bens materiais e culturais, como acontecera nos países considerados como desenvolvidos, a começar pelo acesso à educação e à saúde. Foi assim que surgiu o intenso debate sobre o sentido do conceito do desenvolvimento. Para Veiga (2008), essa controvérsia, que ainda existe, relacionando o desenvolvimento exclusivamente com crescimento econômico sofreu um significativo abalo esclarecedor desde que o Programa das Nações Unidas para o Desenvolvimento (PNUD) passou a divulgar anualmente, a partir da década de 1990, o Índice de Desenvolvimento Humano (IDH), que não se resume à renda per capita ou à renda por trabalhador, conforme fica claro em trecho do Relatório de Desenvolvimento Humano de 2009:

Diferentemente da perspectiva do crescimento econômico, que vê o bem-estar de uma sociedade apenas pelos recursos ou pela renda que ela pode gerar, a abordagem do desenvolvimento humano procura olhar diretamente para as pessoas, suas experiências, seus problemas e a partir disso tentar enxergar o todo. (PNUD, 2009, p.13).

Muito além do debate semântico, é importante, como expõe Sachs em prefácio para Veiga (2008), deixar bem claro que o desenvolvimento não se confunde com o 
crescimento econômico, e que este constitui uma condição necessária, porém não suficiente.

Nesse sentido, Furtado (2004) chama atenção para o fato de que o crescimento econômico vem se fundando na preservação de privilégios das elites que satisfazem o seu desejo por modernização e que o desenvolvimento se caracteriza pelo seu projeto social subjacente. "Dispor de recursos para investir está longe de ser condição suficiente para preparar um melhor futuro para a massa da população. Mas quando o projeto social prioriza a efetiva melhoria das condições de vida dessa população, o crescimento se metamorfoseia em desenvolvimento" (FURTADO, 2004, p.484).

Ainda segundo o autor, essa metamorfose não se dá de forma espontânea. Ela é fruto de um projeto, expressão de uma vontade política. “As estruturas dos países que lideram o processo de desenvolvimento econômico e social não resultaram de uma evolução automática, inercial, mas de opção política orientada para formar uma sociedade apta a assumir um papel dinâmico nesse processo" (FURTADO, 2004, p.484).

Com relação ao conceito de desenvolvimento, Sachs (2008) enfatiza que houve dois avanços expressivos. O primeiro está relacionado à atenção dada desde a década de 1970 à problemática ambiental, que levou a uma ampla reconceituação do desenvolvimento, renomeado atualmente de desenvolvimento sustentável. "O desenvolvimento sustentável obedece ao duplo imperativo ético da solidariedade com as gerações presentes e futuras, e exige a explicitação dos critérios de sustentabilidade social e ambiental e de viabilidade econômica" (SACHS, 2008, p.36). O segundo avanço e possivelmente, de acordo com Ignacy Sachs, o mais importante em termos de uma reconceituação está diretamente relacionado com o trabalho desenvolvido pelo indiano Amartya $\mathrm{Sen}^{22}$, em que o desenvolvimento pode ser redefinido em termos da universalização e do exercício efetivo de todos os direitos humanos.

Para Veiga (2008), está na obra de Sen a mudança fundamental no modo de se entender o desenvolvimento. Segundo o autor, existem três respostas para o questionamento acerca "do que é o desenvolvimento": a primeira seria a que o reduz simplesmente a crescimento econômico; a segunda estaria ligada ao mito, a inexistência real de um desenvolvimento, visto de forma derrotista como inexequível; e, por último, o caminho do meio, que tem seus fundamentos em Sen, que procura demonstrar a

\footnotetext{
22 Prêmio Nobel de Economia em 1998, é reconhecido por ter colaborado com o economista paquistanês
} Mahbub ul Haq na criação do Índice de Desenvolvimento Humano (IDH). 
necessidade de se reconhecer o papel "das diferentes formas de liberdade no combate às absurdas privações, destituições e opressões" que existem no mundo. O livro Desenvolvimento como Liberdade, que reúne conferências realizadas por Sen, é a obra que "certamente mais traz respostas positivas e diretas à pergunta: o que é desenvolvimento" (VEIGA, 2008, p.33).

No livro, Sen (2000) apresenta o desenvolvimento como um processo de expansão das liberdades reais que as pessoas usufruem, enfoque que contrasta com visões mais restritas de desenvolvimento, como as que relacionam o desenvolvimento com o crescimento do Produto Nacional Bruto (PNB), industrialização, aumento de rendas pessoais, modernização social ou avanço tecnológico.

O crescimento do PNB ou das rendas individuais obviamente pode ser muito importante como um meio de expandir as liberdades desfrutadas pelos membros da sociedade. Mas as liberdades dependem também de outros determinantes, como as disposições sociais e econômicas (por exemplo os serviços de educação e saúde) e os direitos civis (por exemplo, a liberdade de participar de discussões e averiguações públicas) (SEN, 2000, p.17).

Para Sen (2000), a liberdade é o principal fim e o principal meio do desenvolvimento, e este "requer que se removam as principais fontes de privação de liberdade: pobreza e tirania, carência de oportunidades econômicas e destituição social sistemática, negligência dos serviços públicos e intolerância ou interferência excessiva de Estados repressivos" (SEN, 2000, p.18).

A expansão da liberdade é vista como fim e principal meio de desenvolvimento, que então consiste na eliminação de tudo que limita as oportunidades e escolhas das pessoas. O crescimento econômico pode ajudar muito, mas o desenvolvimento enquanto liberdade depende de muitas outras questões, tais como educação, saúde e direitos civis.

Sen (2000) apresenta cinco perspectivas de liberdades instrumentais que na ótica do desenvolvimento como liberdade ligam-se umas às outras, contribuindo com o aumento da liberdade humana em geral. Essas liberdades são denominadas pelo autor como: liberdades políticas; facilidades econômicas; oportunidades sociais, garantias de transparência; e segurança protetora. Em uma visão mais integradora dessas liberdades, Sen identifica que:

Liberdades políticas (na forma de liberdade de expressão e eleições livres) ajudam a promover a segurança econômica. Oportunidades sociais (na forma de serviços e educação e saúde) facilitam a participação econômica. Facilidades econômicas (na forma de 
participação no comércio e na produção) podem ajudar a gerar abundância individual, além de recursos públicos para os serviços sociais. Liberdades de diferentes tipos podem fortalecer umas as outras (SEN, 2000, p. 26).

No cerne do pensamento de Sen, os fins e os meios do desenvolvimento exigem que a liberdade esteja no centro de tudo. Nessa perspectiva, "as pessoas têm de ser vistas como ativamente envolvidas - dada a oportunidade - na conformação do seu próprio destino, e não beneficiárias passivas dos frutos engenhosos dos programas de desenvolvimento" (SEN, 2000, p.71).

Esse desenvolvimento, que é proposto por Sen, coloca o Estado e a sociedade para assumir os papéis de fortalecer e proteger as capacidades humanas, mas na forma de sustentação e não de entrega sob encomenda, mantendo sempre a liberdade como centro do desenvolvimento.

Diante do contexto apresentado, fica claro que o desenvolvimento não pode ser visto apenas como uma questão econômica, mas sim como uma proposta de transformação da sociedade, de crescimento sustentável e sustentado. Entendemos que ações que visem ao desenvolvimento devem se voltar para o arranjo de oportunidades sociais adequadas, que proporcionem aos indivíduos melhora nas condições de vida.

\subsubsection{Desenvolvimento rural}

De acordo com o Documento de Referência da $2^{\mathrm{a}}$ Conferência Nacional de Desenvolvimento Rural Sustentável e Solidário (2013), organizada pelo Ministério do Desenvolvimento Agrário (MDA), o conceito de desenvolvimento rural não é entendido como modernização agrícola, nem como industrialização ou urbanização do campo. $\mathrm{O}$ desenvolvimento rural está associado à ideia de criação de capacidades - humanas, políticas, culturais, técnicas etc.- que permitam às populações rurais agir para transformar e melhorar suas condições de vida, por meio de mudanças em suas relações com as esferas do Estado, do mercado e da sociedade civil. Para tanto, é indispensável que essas populações ampliem seu acesso a recursos materiais e simbólicos - terra, crédito, conhecimento e informações, organização etc, a bens e serviços - públicos e privados - e a oportunidades - de emprego, geração de renda, saúde, educação etc. originadas principalmente nas políticas públicas, mas também em mercados. Ademais, esse processo de ampliação de capacidades e de acessos que caracteriza o desenvolvimento rural deve também criar condições para que as populações possam 
precaver-se contra o aumento dos riscos - sociais, ambientais, econômicos, entre outros - normalmente associados a processos complexos de mudança social implícitos na consideração do desenvolvimento.

Para Schneider e Tartaruga (2005, p.17) o desenvolvimento rural está ligado aos processos de mudanças sociais, que buscam promover a qualidade de vida, a ampliação da justiça social, as liberdades individuais e a emancipação política. Esses autores definem desenvolvimento rural como "o processo que resulta das ações articuladas, que visam induzir mudanças socioeconômicas e ambientais no âmbito do espaço rural para melhorar a renda, a qualidade de vida e o bem-estar das populações rurais".

Também para Kageyama (2008), o desenvolvimento rural não pode ser identificado como mero desenvolvimento econômico, mas sim como um processo que envolve múltiplas dimensões: econômica, sociocultural, político institucional e ambiental.

Wanderley (2004) aponta que uma nova visão do rural está em curso. Visto sempre como fonte de problemas (miséria, isolamento, currais eleitorais etc.), o meio rural começa a ser percebido como um portador de soluções. Essa percepção positiva encontra no espaço rural alternativas para o problema do desemprego, como ainda uma proposta de melhoria da qualidade de vida e de aprofundamento das relações sociais e pessoais. Na mesma linha, Veiga fala em "casamento da cidade e do campo", sinalizando o "nascimento" de uma nova ruralidade, em que as áreas rurais estão cada vez mais valiosas à qualidade de vida, ou ao bem-estar, pela ação da "conservação do patrimônio natural, aproveitamento econômico das decorrentes amenidades e a exploração de novas fontes de energia" (VEIGA, 2006, p.335).

Kageyama (2008, p.73), em uma abordagem mais aplicada, destaca que "no Brasil, a agricultura continua, sem dúvidas, a ser a principal atividade do meio rural e, por conseguinte, não pode ser desprezada na análise do desenvolvimento rural”. No entanto, também precisam ser observadas as características fundamentais das novas trajetórias desse processo, que são: a diversidade - de atores envolvidos, de atividades empreendidas e de padrões de motivações emergentes - e a multifuncionalidade - que implica em novas formas de uso dos recursos como terra, trabalho, conhecimento e natureza.

Assim, com base no pensamento de Knickel e Renting, Kageyama (2008) entende que o desenvolvimento rural consiste em uma grande variedade de novas atividades, como produção de bens de alta qualidade, conservação da natureza e da 
paisagem e o agroturismo, as quais se caracterizam pela multidimensionalidade, multifuncionalidade e elevado grau de integração.

Van der Ploeg et al. (2000, apud Kageyama, 2008) apontam que na Europa, o paradigma da modernização da agricultura, como principal ferramenta para elevar a renda e levar desenvolvimento às comunidades rurais, tem sido suplantado pelo paradigma do desenvolvimento rural, buscando um novo modelo para o setor agrícola. Esse novo modelo traz novos objetivos como a produção de bens públicos (paisagem), sinergias com ecossistemas locais, valorização das economias de escopo $^{23}$, em detrimento da de escala, e a pluriatividade das famílias rurais.

O desenvolvimento rural implica a criação de novos produtos e novos serviços, associados a novos mercados; procura formas de redução de custos a partir de novas trajetórias tecnológicas; tenta reconstruir a agricultura não apenas no nível dos estabelecimentos, mas em termos regionais e da economia rural como um todo (KAGEYAMA, 2008, p.63).

Nesse contexto, é possível dizer que o desenvolvimento rural deve estar pautado na combinação do aspecto econômico, no que se refere ao aumento do nível da estabilidade da renda da família, do aspecto social, com a obtenção de um nível de vida socialmente aceitável, e do ambiental. Também deve ser entendido que um dos seus principais pilares é a pluriatividade, ou seja, a diversificação das atividades que geram renda. Essas características do desenvolvimento rural são apresentadas como alternativas ao modelo de modernização da agricultura, "que é caracterizado por agricultores com perfil de empresários agrícolas, produções especializadas, especialmente de commodities, que obtêm ganhos de escala, baseadas no uso intensivo de insumos e orientadas para poucos mercados" (PONCHIO, 2010, p.43).

\footnotetext{
${ }^{23}$ No campo da economia, existe o conceito de economia de escopo, que ocorre nas situações em que há maximização de lucros com a produção simultânea de mais de um produto, a chamada produção conjunta. A economia de escopo só se define quando a produção dos produtos separadamente se mostra mais onerosa. A economia de escopo é resultado da utilização da mesma matéria-prima na produção de tais produtos. É comum que exista economia de escopo em empresas diversificadas; neste caso, o escopo é a variedade de produtos que podem ser produzidos conjuntamente, a partir da mesma matéria-prima, para atingir o lucro máximo.
} 


\subsection{Políticas públicas de comunicação no contexto do desenvolvimento rural no}

\section{Brasil}

Segundo Tauk Santos (2012), pensar a comunicação para o desenvolvimento no atual contexto rural implica em reconhecer a evidência de que o modelo de comunicação para o desenvolvimento depende da política de desenvolvimento adotada em cada época. "A comunicação para o desenvolvimento dos contextos rurais brasileiros esteve sempre, historicamente, atrelada às políticas públicas do Estado" (TAUK SANTOS, 2012, p.01).

Nesse sentido, a autora constrói uma linha de pensamento que aponta a forma como o desenvolvimento é entendido em determinados períodos e como são estabelecidas as formas de comunicação para o desenvolvimento a partir da política governamental adotada.

O primeiro modelo de comunicação para o desenvolvimento no Brasil aparece, assim como no restante do mundo, logo após o término da Segunda Guerra Mundial. Nesse período, é criado o serviço de Extensão Rural pelo governo brasileiro, que, objetivando viabilizar a política modernizadora no campo, importa, com o apoio de diversas organizações internacionais, o modelo difusionista estadunidense. Com esse foco, o governo cria ainda um sistema de Comunicação Rural, segundo preceitos do manual Planejamento do Trabalho em Extensão Agrícola, elaborado por Willy Timmer, que recomendava persuadir as populações rurais a aceitar o que lhe era proposto. "Referia-se às informações tecnológicas que a gente ocupada em atividades agrícolas deveria incorporar para que as mudanças sociais acontecessem na direção pretendida: a modernização do campo" (TAUK SANTOS, 2010, p.02).

A partir desse modelo de desenvolvimento induzido, a comunicação figura como a viabilizadora das políticas modernizadoras do Estado que incorpora a tarefa de promotor e provedor do desenvolvimento nacional. A principal crítica a esse modelo de comunicação aparece na década de 1970, no livro Extensão ou Comunicação?, de Paulo Freire, que retruca a postura persuasora subjacente do modelo difusionista adotado como política estatal (TAUK SANTOS, 2012, p.02).

Segundo Tauk Santos (2012), foi somente com a flexibilização dos regimes autoritários na década de 1980, particularmente no Brasil, que o Estado brasileiro incorporou o discurso da participação popular na comunicação para o desenvolvimento, mas a autora salienta, entretanto, "que essa postura não representou uma ruptura com o 
modelo difusionista modernizador, e sim a perspectiva de alinhar o discurso do Estado à onda avassaladora de democratização que varria o País" (TAUK SANTOS, 2012, p.04).

As mudanças que determinam os novos sentidos do desenvolvimento na década de 1990 têm a globalização como uma das principais referências. A globalidade, como assinala Thornthon (2006 apud TAUK SANTOS, 2012), inclui muitas dimensões como a tecnológica, a econômica, cultural, político-institucional e ambiental que têm como referente político o modelo democrático e, no domínio econômico, a ideologia capitalista. Os sistemas econômicos estão direcionados para a liberalização da economia, a desregulamentação dos mercados e a redução do Estado, mantendo como figura central a confiança no papel dos mercados como avalizadores de recursos e na crença de que o crescimento econômico garantiria necessariamente benefícios ao conjunto da sociedade.

Também nesse período, o Estado, por meio do seu processo de descentralização, traz para a agenda das políticas estatais a busca de parcerias e de um maior envolvimento da sociedade civil no controle das ações governamentais. É nesse sentido que são criados o Programa de Combate à Miséria e a Fome (PCMF 1993) e o Programa Comunidade Solidária, em 1996, cuja proposta era dar continuidade ao PCMF, voltado às ações de articular, coordenar e potencializar as iniciativas dos governos federal, estadual e municipal no combate à pobreza (DRAIBE, apud CALLOU e TAUK SANTOS, 2008).

Com esse foco de incentivar o estabelecimento de parcerias, o Estado mobiliza a sociedade civil para participar da gestão de governo com a criação dos conselhos municipais de desenvolvimento com a função de planejar e fiscalizar a aplicação dos recursos financeiros repassados pelo governo federal e estadual para implementação de políticas públicas municipais. O Estado cria ainda programas voltados ao desenvolvimento rural cuja operacionalização requer a participação das comunidades envolvidas, como o Programa de Crédito para a Reforma Agrária (Procera) e o Programa de Apoio à Agricultura Familiar (Pronaf), entre outros (DRAIBE, apud CALLOU e TAUK SANTOS, 2008).

Nesse contexto, segundo Tauk Santos (2010, p.5), o papel da comunicação para o desenvolvimento rural passa a ser a "capacitação para a construção da participação e fortalecimento das organizações nos contextos populares". E é com esse foco que o argumento das políticas públicas volta-se à construção da gestão participativa no âmbito municipal e as estratégias de comunicação passam a ter como proposta a viabilização de 
ações e a promoção do empoderamento das associações populares, compreendida como ação que possibilita a essas entidades melhorarem a capacidade individual e coletiva para atuarem no cenário público; fortalecer as lideranças municipais; articular parcerias com organizações governamentais, não governamentais e população local; além de viabilizar ações permanentes de capacitação e assistência técnica para a população dos contextos rurais envolvidos no processo de desenvolvimento (TAUK SANTOS e CALLOU, 2006).

Mas, de acordo com a autora, com relação à comunicação para o desenvolvimento rural, tanto o modelo governamental, com a proposta de transformar as comunidades rurais a partir de um modelo globalizado de desenvolvimento, como o praticado pelas ONGs, que tinha como princípio o incremento da participação das comunidades rurais, visando enfrentar os efeitos do modelo governamental neoliberal, foram capazes de sedimentar uma proposta de desenvolvimento que garantisse uma racionalidade econômica produtiva, não indo muito além da criação de espaços de democratização política.

$\mathrm{Na}$ fase atual, pós-governo neoliberal, as políticas de desenvolvimento rural passam a se pautar na sustentabilidade e estão focadas na estratégia de fortalecimento de espaços públicos e de formas de diálogo e de participação social. Nessa fase, surge um conjunto de políticas públicas destinadas ao rural e à agricultura familiar. A proposta do Estado é a construção de um novo modelo de desenvolvimento e de reorganização social, buscando o aprofundamento do diálogo entre governo e sociedade civil.

De acordo com Tauk Santos (2010), o desenvolvimento rural hoje assume inúmeros desafios.

Desafios de incorporar ao debate teórico e às políticas públicas de desenvolvimento as novas concepções contemporâneas sobre o espaço rural, que combinam atividades agrícolas e não agrícolas num mesmo território agrário, e as noções de desenvolvimento local e da sustentabilidade (TAUK SANTOS, 2010, p. 07).

O marco legal que sustenta o conjunto de políticas de desenvolvimento rural também evoluiu nos últimos dez anos, tornando-se mais consistente e criando condições para a continuidade das políticas independentemente de transições de governos. Exemplo disso é a Lei $n^{\circ} 11.326 / 2006$, que estabeleceu as diretrizes para a formulação da Política Nacional da Agricultura Familiar e Empreendimentos Familiares Rurais e definiu o público do Brasil Rural, reconhecendo a diversidade de identidades das populações rurais (MDA, 2013). A comunicação assume, assim, o desafio de atender 
essa perspectiva da sustentabilidade, se incorporando aos programas de desenvolvimento e da mudança social, visto que ela sempre estará alinhada com a orientação e o direcionamento estabelecido pelo governo brasileiro, que, atualmente, tem seu foco bastante direcionado às questões de cunho social.

\subsection{Uma noção básica de política aplicada ao contexto da ação pública}

A noção de política é uma referência constante em todas as dimensões do cotidiano. Segundo Maar (2006), ela surge junto com a própria história, com a dinâmica de uma realidade em transformação que frequentemente se revela insuficiente e insatisfatória, resultante da atividade dos próprios homens vivendo em sociedade. Uma vida que deve fluir a partir de um conjunto regulador das ações, comportamentos e regras que conformam e referenciam a convivência coletiva.

De acordo com o Dicionário da Política, a palavra "política" deriva do adjetivo de pólis (politikós), e diz respeito àquilo que é da cidade, e por consequência, ao que é urbano, civil, público, e ainda ao que sociável ou social, que é de interesse do homem e do exercício da cidadania. Com o passar do tempo, a palavra política deixou de ter o sentido de adjetivo e passou a ser comumente usada para "indicar a atividade ou o conjunto de atividades que esteja relacionado com o Estado" (BOBBIO, 1998, p. 954).

Segundo Parada (2007), a política e a política pública são entidades diferentes, mas que se influenciam de maneira recíproca. Ambas se encontram na opacidade do sistema político e tem relação com o poder social. Enquanto a política apresenta um conceito amplo, relativo ao poder de forma geral, a política pública corresponde a soluções específicas de como manejar os assuntos públicos.

Assim, a política pública pode ser entendida como:

Um fluxo de decisões públicas orientado a manter o equilíbrio social ou a introduzir desequilíbrios destinados a modificar essa realidade. Decisões condicionadas pelo próprio fluxo e pelas reações e modificações que elas provocam no tecido social, bem como pelos valores, ideias dos que adotam ou influem na decisão (SARAVIA, 2007, p.12).

Saravia (2007) explica que, no contexto da política pública, a expressão política pode denotar várias coisas, entre elas: um campo da atividade governamental, um propósito geral a ser realizado, uma situação social desejada, uma proposta de ação 
específica, uma norma ou normas que existem para determinada problemática, ou ainda um conjunto de objetivos e programas de ação governamental.

Com base em Villanueva (2007), entendemos que, em primeiro lugar, uma política, no contexto público, é um comportamento propositivo, intencional, planejado, não simplesmente reativo e casual. Coloca-se em movimento com a decisão de alcançar certos objetivos através de certos meios. É uma ação com sentido. Também é o caso da não ação, se for decidido deliberadamente não atuar diante de um problema público.

Em segundo lugar, podemos dizer que a política pública não é uma simples ação de um ator governamental. Tem que incorporar-se às muitas e diversas decisões de todos os atores participantes, governamentais e extragovernamentais, que, em suas diversas interações, preparam e condicionam a decisão central que antecede a prática. A política, nesse contexto, é então um processo, um curso da ação. Nesse sentido, Villanueva (2007) aponta que uma política é um curso de ação em dois sentidos: um curso de ação deliberadamente desenhado e um curso de ação efetivamente seguido.

Uma política de excelência corresponde a cursos de ação e fluxos de informação relacionados com um objetivo definido democraticamente, que são desenvolvidos pelo setor público. "Uma política pública de qualidade incluirá orientações e conteúdos, instrumentos e mecanismos, definições e modificações institucionais e previsões de seus resultados" (PARADA, 2007, p. 68, tradução nossa).

Saravia (2005) aponta que toda política pública apresenta certo grau de institucionalização. Órgãos e entidades já existentes ou criados com esse propósito estarão incumbidos de orientar e, eventualmente, conduzir, financiar, supervisionar e avaliar as atividades destinadas a implementar uma política pública.

Em toda política pública, as instituições públicas desempenham um papel decisivo, uma vez que delas são emanadas ou são condicionadas as principais decisões. "Sua estrutura, seus quadros e sua cultura organizacional são elementos que configuram a política" (SARAVIA, 2007, p.36).

Assim, para compreender a política pública a partir das organizações é necessário entender como operam essas instituições, suas estruturas e os comportamentos dentro delas. No caso da Embrapa, passam pela instituição políticas públicas de cunho científico e tecnológico como ainda algumas voltadas para o universo rural, muitas delas direcionadas para a agricultura familiar e o seu desenvolvimento. A própria empresa, como uma instituição pública, também elabora e implementa políticas em âmbitos distintos, tais como a que é analisada neste trabalho. 


\subsection{Transferência de Tecnologia}

De acordo com Duarte (2004), a transferência de tecnologia tradicionalmente é tratada como uma relação de troca em que a tecnologia é oferecida ao mercado e, na existência de um usuário interessado, é adquirida e paga, mediante um dado valor (embutido em um produto), ou simplesmente há um benefício social causado pela introdução da tecnologia no mercado, o que costuma ser o caso das empresas públicas de pesquisa. Nesse contexto, Christensen e Rocha (1989) conceituam a transferência de tecnologia como "a movimentação de ideias e informações e das possíveis contrapartidas entre os que têm o domínio de uma tecnologia e os que dela necessitam" (CHRISTENSEN e ROCHA, 1989, p. 21).

Ainda em termos conceituais, no Marco Referencial de Transferência de Tecnologia, Intercâmbio e Construção do Conhecimento da Embrapa, como já apresentado no capítulo anterior, a transferência de tecnologia é entendida da seguinte forma:

[...] como um componente do processo de inovação, no qual diferentes estratégias de comunicação e interação são utilizadas por grupos de atores com o objetivo de dinamizar arranjos produtivos, mercadológicos e funcionais, por meio da difusão de soluções tecnológicas (EMBRAPA, 2014, p.7).

Gibbons (1994) propõe um conceito baseado na interação entre o gerador da tecnologia e o usuário, sugerindo uma mudança na terminologia de transferência de tecnologia para intercâmbio de tecnologia, rompendo com uma concepção antiga que liga o processo ao modelo difusionista. Para Gibbons não basta simplesmente transferir a tecnologia do gerador para o receptor, é necessário promover um intercâmbio constante entre esses atores.

Nessa linha, Duarte identifica que em empresas públicas que geram tecnologia é tão importante promover a interação com o usuário final, quanto o sucesso no seu objetivo de pesquisa e desenvolvimento. "O relacionamento e o fluxo de informação entre geradores e usuários cria ambiente que capacita o pesquisador a aperfeiçoar sua prática e atender as demandas mais facilmente" (DUARTE, 2004, p.62).

Para a área agrícola, é de grande importância a oferta de informações que permitam ao agricultor conhecer as opções possíveis para produzir mais, evitar perdas, preservar o meio ambiente, vender melhor etc. Essas informações adquirem valor 
quando atendem aos requisitos de disponibilidade, viabilidade econômica e social e adequação temporal, sendo seu uso condicionado a vários fatores e variáveis. De acordo com Duarte (2004), entre esses fatores e variáveis estão o conhecimento da tecnologia pelos interessados, como também a sua viabilidade econômica, social e cultural, e a disponibilidade de informações.

A adoção de tecnologias geradas por empresas de pesquisa exige muito mais que o desenvolvimento de processos e produtos úteis para o setor da agricultura. Dessa forma, é necessário que se tenha como foco também a transferência de tecnologia, estimulando o treinamento de pessoal, o reprocessamento e a oferta de conhecimento e ainda apoiar a formação de redes que cooperam para a busca e uso de informação tecnológica.

No desenvolvimento deste trabalho, partimos do entendimento de que transferência de tecnologia é um processo de interação e intercâmbio, que só se completa com a efetiva incorporação de um conhecimento ou tecnologia por um usuário. Entendemos também que novos conhecimentos e a adoção de tecnologias podem mudar positivamente as condições produtivas e a qualidade de vida dos agricultores e que isso está diretamente ligado ao processo de transferência de tecnologia.

\subsection{Tecnologia Agrícola}

Em uma perspectiva geral, podemos dizer que tecnologia agrícola designa produtos físicos e processos. Os produtos físicos podem ser do tipo químico, biológico e mecânico (agroquímicos, sementes, máquinas e equipamentos) e os processos envolvem geralmente conhecimento de como cultivar ou criar, tratar a terra ou formas de gerenciamento. De acordo com Duarte (2004), as inovações, como drenagem e irrigação, também são consideradas tecnologias agrícolas.

Conforme esse mesmo autor nos explica, na área agrícola o progresso técnico é traduzido em novos processos de gestão agroindustrial, padrões de qualidade e conformidade, padrões sanitários, produtos alimentícios e industriais, adoção intensiva de automação, tecnologia da informação e biossegurança. "O uso de tecnologia passa, então, a ser fundamental, por alterar os fatores de produção e estabelecer, para o agricultor, relação mais favorável entre custo e produção" (DUARTE, 2004, p. 57). 
Para Ramalho e Contini (1988), a tecnologia agrícola pode ser entendida como o domínio do homem sobre a natureza com a aplicação do conhecimento científico que se incorpora materialmente em um bem qualquer ou em um conjunto de conhecimentos sobre como viabilizar uma cultura ou criação.

Com relação ao processo de produção de uma tecnologia, Duarte (2004) argumenta que esse pode envolver uma etapa de pesquisa e desenvolvimento e outra em que o mercado incorpora os avanços para um aumento de produtividade ou uma redução, que pode ser tanto de custos quanto de esforços.

Algumas tecnologias podem substituir apenas partes de um sistema em uso, enquanto outras correspondem a um conjunto de práticas que o mudam radicalmente ou até mesmo o substituem.

\subsection{Informação Tecnológica}

Segundo Duarte (2004), informação tecnológica está relacionada ao processo humano de obter conhecimento. É uma expressão muito utilizada no Brasil e apresenta várias definições, sendo muitas vezes empregada como sinônimo de informação industrial, na perspectiva de insumo fundamental do desenvolvimento de produtos que permitam a manutenção de competitividade. O conceito pode ainda ser ampliado ao ser aplicado no âmbito de pesquisa e desenvolvimento, transportes, suprimentos, sistemas de informática etc.

Para Januzzi (2002) a questão é que tanto informação, quanto tecnologia, têm significado semântico múltiplo e são adotados conforme o contexto em que se inserem. Tecnologia está relacionada a processos e produtos inovadores do ponto de vista do usuário e, portanto, "informações referentes à aquisição, inovação e transferência de tecnologia são, sem dúvida, tecnológicas” (JANUZZI, 2002, p. 121).

Januzzi (2002) aponta uma confusão conceitual sobre diferentes definições de informação tecnológica, percebendo que o termo pode ter diferentes significados para setores diversos de uma mesma empresa, podendo ser utilizado como sinônimo de informação científica e tecnológica, informação industrial, informações para negócios, como ainda para tecnologia da informação.

A variedade de usos conduz à adaptação a situações específicas, desde que exista um quadro de referência para usuário. Assim, entendemos que o conceito proposto por Alvares é particularmente adequado para este trabalho por ter como foco os processos 
aplicados para o desenvolvimento do setor produtivo: "todo tipo de conhecimento sobre tecnologia de fabricação, de projeto e de gestão que favoreça a melhoria contínua no setor produtivo" (ALVAREZ apud JANUZZI 2002, p.49).

Discutir informação tecnológica e seu uso na agricultura, de acordo com Duarte (2004), exige também compreender que cada cultivo possui restrições biológicas, de manejo, de custos financeiros que implicam em um outro tipo de informação: sobre o uso, manejo e adequação a cada tipo de solo, clima e uso de adubo. Neste caso, temos a informação tecnológica que não se refere a determinado produto especificamente, "mas a um bem público que permite produzir de forma mais eficiente, reduzindo custos, produzindo de modo mais sustentável, ao tornar-se uma inovação em um sistema produtivo" (DUARTE, 2004, p.63). 


\section{ANÁLISE DOS DADOS}

Os dados apresentados neste capítulo estão organizados de acordo com as categorias de análise elencadas no capítulo sobre metodologia, podendo estar expostos tanto na forma quantitativa, quanto qualitativa. Por existirem algumas diferenças nas percepções dos empregados da Embrapa que atuam na Sede, em relação às daqueles que atuam em Unidades, criamos em determinados momentos uma divisão, visando possibilitar um melhor entendimento por parte do leitor das posições encontradas. Da mesma forma, em alguns momentos se fez necessário apresentar os dados dos agricultores com uma divisão por estado.

\section{1) A VISÃO DOS AGRICULTORES FAMILIARES}

\section{a) Desenvolvimento de tecnologias pela Embrapa para a agricultura familiar}

Questionados se a Embrapa desenvolve tecnologias para a agricultura familiar, $88 \%$ (30) dos agricultores entrevistados do Rio Grande do Sul e $76 \%$ (26) dos entrevistados de Goiás responderam que sim. Houve ainda um número de agricultores que disse não saber, correspondendo a 9\% (3) dos respondentes no Rio Grande do Sul e $21 \%$ (7) em Goiás. Apenas um entrevistado em cada estado afirmou que a Embrapa não desenvolve tecnologias para o segmento.

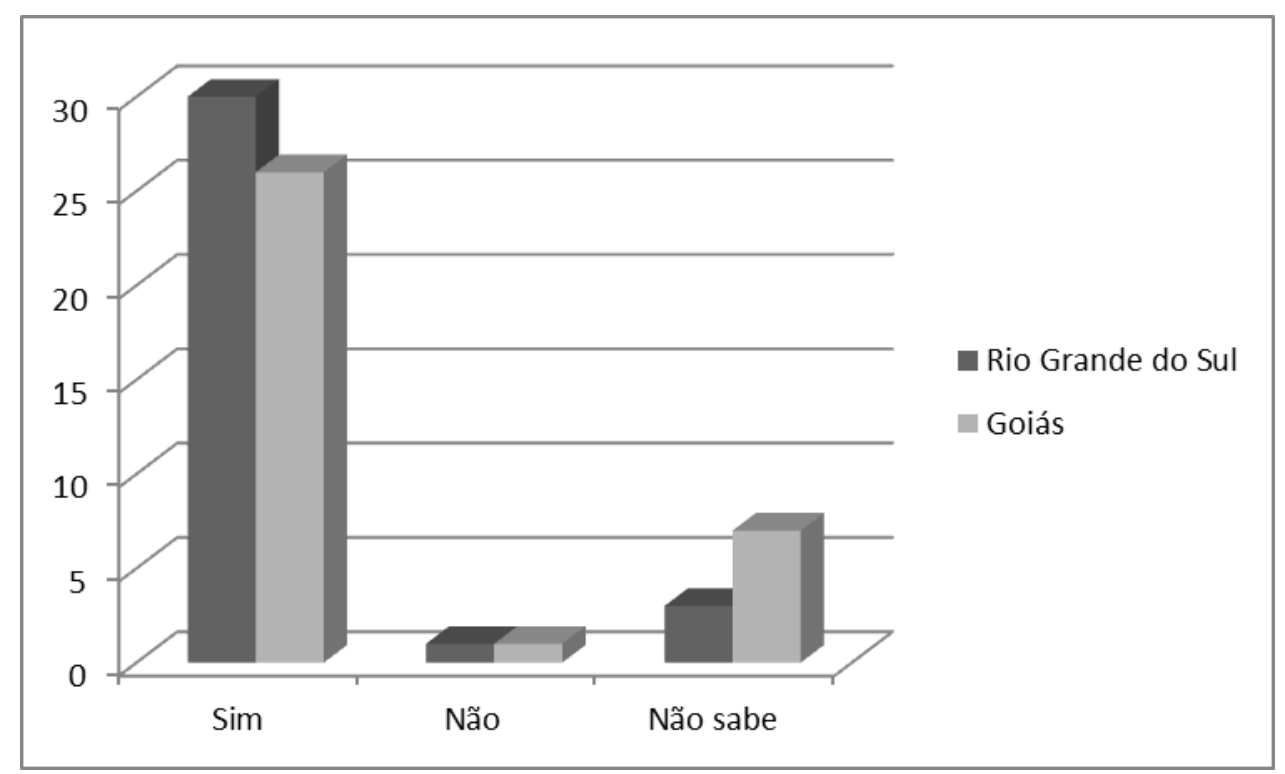

Gráfico 1: Desenvolvimento de tecnologias para a agricultura familiar 
$\checkmark$ Síntese: Predomina, entre os agricultores familiares, o entendimento de que a Embrapa desenvolve tecnologias para o segmento.

\section{b) Conhecimento e percepção acerca da Embrapa}

Perguntados se conheciam alguma tecnologia gerada pela Embrapa, 97\% (33) dos agricultores gaúchos e 88\% (30) dos goianos responderam que sim. Quanto a terem usado as tecnologias geradas pela Embrapa, no Rio Grande do Sul 73\% (25) dos agricultores afirmam que sim, enquanto em Goiás o número de agricultores que faz a mesma afirmação é de 67\% (23). Um total de cinco agricultores, três do Rio Grande do Sul e dois de Goiás, diz não saber se já usaram ou não tecnologias da Embrapa.

Em ambos os estados foi possível verificar que a Embrapa possui uma boa reputação entre todos os agricultores entrevistados, que revelaram uma percepção bastante positiva da instituição e do papel desempenhado por esta empresa pública de pesquisa agropecuária. No entanto, encontramos em 15\% (5) dos entrevistados de Goiás e em 12\% (4) dos entrevistados do Rio Grande do Sul respostas que elogiam a Embrapa, mas que tecem críticas à sua atuação junto aos agricultores familiares, impactando diretamente na percepção do entrevistado sobre a instituição.

Eu tenho uma boa impressão [da Embrapa], mas acho que ainda estão devendo bastante. Notei que, nos últimos anos, eles estão correndo atrás. Eles estão tentando fazer pesquisa que eu posso usar. Acredito que tem muito trabalho que o pesquisador fez para ele, por causa da pósgraduação, e não para o uso do público-alvo. Que seria a função dele. Nos últimos anos eles têm tentado melhorar, tentado mudar a realidade com o conhecimento que eles têm na pesquisa. E é o que deve ser. (Agricultor 2 - Rio Grande do Sul)

A Embrapa é uma coisa importante para a agricultura, eu sei que é. Mas como eu não trabalho direto com ela, ela fica de lado. Mesmo assim, sei que para mim e para todo mundo ela é importante. (Agricultor 34 - Rio Grande do Sul) 
Eu creio que [a Embrapa] seja uma instituição boa, só que devia divulgar mais. Não sei se pelo rádio ou pela TV. Eu nasci e fui criado na roça e não tenho nem a metade da noção do que é a Embrapa, e eu tenho certeza que ainda aqui na região tem mais gente desinformada que eu. (Agricultor 28-Goiás)

A Embrapa é uma empresa do governo que trabalha com pesquisa, mas que mantém mais para ela mesma. Parece que ela está distante do produtor. (Agricultor 31 - Goiás)

$\checkmark$ Síntese: Os agricultores familiares, em sua maioria, conhecem tecnologias geradas pela Embrapa, e uma parcela deles já chegou a usá-las. A percepção acerca da Embrapa e do papel desempenhado por ela é positiva. Entretanto, existem descontentamentos acerca da atuação desta instituição pública de pesquisa agropecuária com o segmento específico da agricultura familiar.

c) Comunicação e divulgação da Embrapa

\section{$\underline{\text { Rio Grande do Sul }}$}

Quando questionados sobre o que achavam da divulgação das tecnologias da Embrapa e da comunicação da empresa com os agricultores familiares, 91\% (31) dos entrevistados do Rio Grande do Sul afirmam que de alguma forma recebem informações sobre a instituição e que notam que a Embrapa procura, de alguma maneira, se comunicar com eles, enquanto $9 \%$ (03) afirmam não perceber movimentos comunicacionais da empresa. Entretanto, 53\% (18) do total de entrevistados aponta que nem sempre a comunicação da Embrapa atende as suas expectativas, afirmando que as informações são escassas ou fragmentadas. Para 38\% (13), a comunicação está dentro das suas expectativas.

Alguma coisa tem chegado através dos técnicos da Emater, mas para nós ela é fraca, não chega bem àquilo que a gente esperava. (Agricultor 17 Rio Grande do Sul) 
A comunicação é boa e os técnicos são prestativos, mas as informações são escassas. Tem estudo da mandioca, tem batata-doce e outras coisas. Tudo isso chega, mas precisa mais. Quando chega tem qualidade. É necessário que se mude, que se trabalhe mais em cima da agricultura familiar. (Agricultor 18 - Rio Grande do Sul)

A comunicação é boa, mas sempre pode divulgar mais coisas. A informação chega pouco, mas a gente tem que procurar também. (Agricultor 26 - Rio Grande do Sul)

Acho boa. Pelo menos hoje já tem essa comunicação. Antes não tinha. Não vou te dizer que não possa ser melhor. Se eu dizer que está bom, vão achar que esse cara já não tem ambição de nada. Tem que ter perspectivas melhores. (Agricultor 31 - Rio Grande do Sul)

Ainda sobre a divulgação das tecnologias da Embrapa e da comunicação da empresa com os agricultores familiares, um entre os 34 entrevistados do Rio Grande do Sul fez considerações totalmente negativas sobre a comunicação da instituição com os agricultores familiares.

Acho que a Embrapa faz coisas só para quem tem mais estrutura, é mais capitalizado. Como eles procuram mais essas pessoas, a comunicação com os agricultores familiares é péssima. (Agricultor 27 - Rio Grande do Sul)

Chama atenção o fato de $73 \%$ (25) dos agricultores entrevistados no Rio Grande do Sul atribuírem o não recebimento de informações sobre tecnologias ou ações da Embrapa à falta de interesse por parte dos próprios produtores ou ao fato de que muitos destes não buscam tais informações. Os agricultores que afirmam isso e dizem ter conhecimento acerca da Embrapa se colocam em uma posição de interessados e afirmam que buscam tais informações ou via Emater, ou diretamente na própria Embrapa. 
Quem tem interesse é só buscar ou ligar para eles que eles te dão tudo, a resposta certa. Quem quiser saber eles dão atenção. Tanto faz pequeno, médio ou grande, quem tem vontade de saber as coisas vai ter acesso. (Agricultor 13 - Rio Grande do Sul)

A comunicação da Embrapa atende, mas precisa a pessoa buscar também, tem que correr atrás. Não adianta ficar em casa e esperar tudo de mão beijada. Eu acho que as informações estão acessíveis. (Agricultor 15 - Rio Grande do Sul)

Para ser sincero, se eu quero uma coisa eu encontro. Mas, como eu te disse, ela está bastante divulgada, quem tiver interessado vai em busca e acha. (Agricultor 23 - Rio Grande do Sul)

Há ainda seis agricultores gaúchos que apontaram o fato de novas pessoas terem sido contratadas na Embrapa, e na própria Emater, como fator facilitador da comunicação ou do recebimento de informações sobre o que a empresa produz, dizendo ter havido uma mudança a partir de um determinado tempo. Esses atribuem um resultado mais positivo com relação à comunicação da instituição às pessoas responsáveis por essa área, valorizando as relações pessoais, independentemente de vínculos institucionais.

As coisas melhoraram de um tempo para cá com a chegada de um técnico novo na Embrapa, mas acho que é coisa da pessoa e não dá instituição. (Agricultor 2 -Rio Grande do Sul)

Pegou a melhorar de um tempo para cá. A Emater de primeiro aparecia quase nunca. Daí, começamos a ter notícias da Embrapa por meio da Emater. Alguma coisa mudou, acho que um funcionário se interessou. (Agricultor 32 - Rio Grande do Sul) 


\section{Goiás}

Em Goiás, 71\% (24) dos agricultores entrevistados afirmam que a comunicação da Embrapa com os agricultores familiares não funciona bem, enquanto 11\% (4) dos entrevistados estão totalmente satisfeitos com a comunicação realizada pela empresa. Mas, para 18\% (6) dos agricultores familiares, a comunicação da instituição com o segmento não existe. Entre os entrevistados goianos, a televisão aparece como a maior divulgadora das tecnologias da Embrapa.

Acho que pouquíssimas pessoas estão sabendo das coisas que a Embrapa faz ou o que poderia auxiliar a gente na parte de tecnologias. Acho que a Embrapa deveria divulgar melhor, principalmente para englobar todo tipo de agricultor que ela almeja. Pelo menos divulgar um folderzinho, um dia de campo ${ }^{24}$, uma demonstração do que fosse fazer. (Agricultor 15-Goiás)

Aí é como se fosse um grão de areia. Se a gente tivesse mais acesso a ela ficaria mais fácil. Chega pouca informação dela aqui, só pela Emater e pela televisão. Na internet tem, mas a gente não sabe mexer, tem que pedir tudo para os filhos. Sobre tecnologia agrícola tem muita falha, as informações não chegam para gente ou a gente está perguntando pouco. (Agricultor 16-Goiás)

Não fico sabendo da Embrapa, mas a gente deveria ficar sabendo. Com uma tecnologia melhor a gente poderia trabalhar mais seguro. As coisas podiam ser melhores. Acho que ela tenta se comunicar, mas neste setor aqui ninguém fica sabendo de nada, só pela TV. (Agricultor 19 - Goiás)

As informações vêm tudo pelo Globo Rural. Para mim, ela não funciona direito, mas tem o outro lado também, a gente nunca foi atrás. Talvez se a gente buscasse seria diferente. Pode ser que exista um movimento de comunicação, mas a gente ainda não sabe se eles querem saber da gente.

\footnotetext{
${ }^{24}$ Dia de campo, na concepção de Santos (2006, p.21), é um “evento direcionado a determinado público, convidado a visitar e conhecer os campos experimentais ou áreas demonstrativas da Embrapa".
} 
O que chega é muito pouco. Aqui não tem nem convite da Emater para palestra. (Agricultor 29 - Goiás)

Assim como no Rio Grande do Sul, a falta de acesso ou de informações da Embrapa foi atribuída por 47\% (16) dos entrevistados de Goiás também a uma ausência de interesse ou de pró-atividade em buscar a empresa.

Não chega muita informação aqui, não. A gente fica sabendo mais por algum agricultor que tem mais relação com aquele órgão. Quem participa mais, fica sabendo de mais coisa. Quem fica acomodado, acaba ficando de fora. (Agricultor 13 - Goiás)

A informação chega, a não ser que a pessoa não tenha interesse. Quem está no ramo tem conhecimento, mesmo que pouco, mas tem. A comunicação é muito importante. Teria que melhorar um pouco, mas é de cada pessoa, se a pessoa está interessada ela teria de ir ver. Eu, quando quero alguma coisa, corro atrás. (Agricultor 20 - Goiás)

Tô atrasado por falta de informação, mas também por falta de interesse, se eu quisesse mesmo a gente ia atrás, corria ali e perguntava pro pessoal. Eu nunca fui. Também falta um pouco de interesse da parte da gente. (Agricultor 25 - Goiás)

$\checkmark$ Síntese: Com relação à comunicação da Embrapa voltada para a agricultura familiar, houve uma sensível diferença entre os dois estados, pois enquanto no Rio Grande do Sul os agricultores se mostraram mais otimistas com relação à comunicação da Embrapa, em Goiás há a percepção de que a comunicação não está adequada ou não atende às expectativas e é significativamente maior. 


\section{d) Recepção de informações e conhecimento de veículos de comunicação da Embrapa}

No Rio Grande do Sul, 91\% (31) dos entrevistados afirmam que costumam receber informações sobre as tecnologias da Embrapa, enquanto no estado de Goiás esse número cai para $61 \%(21)$.

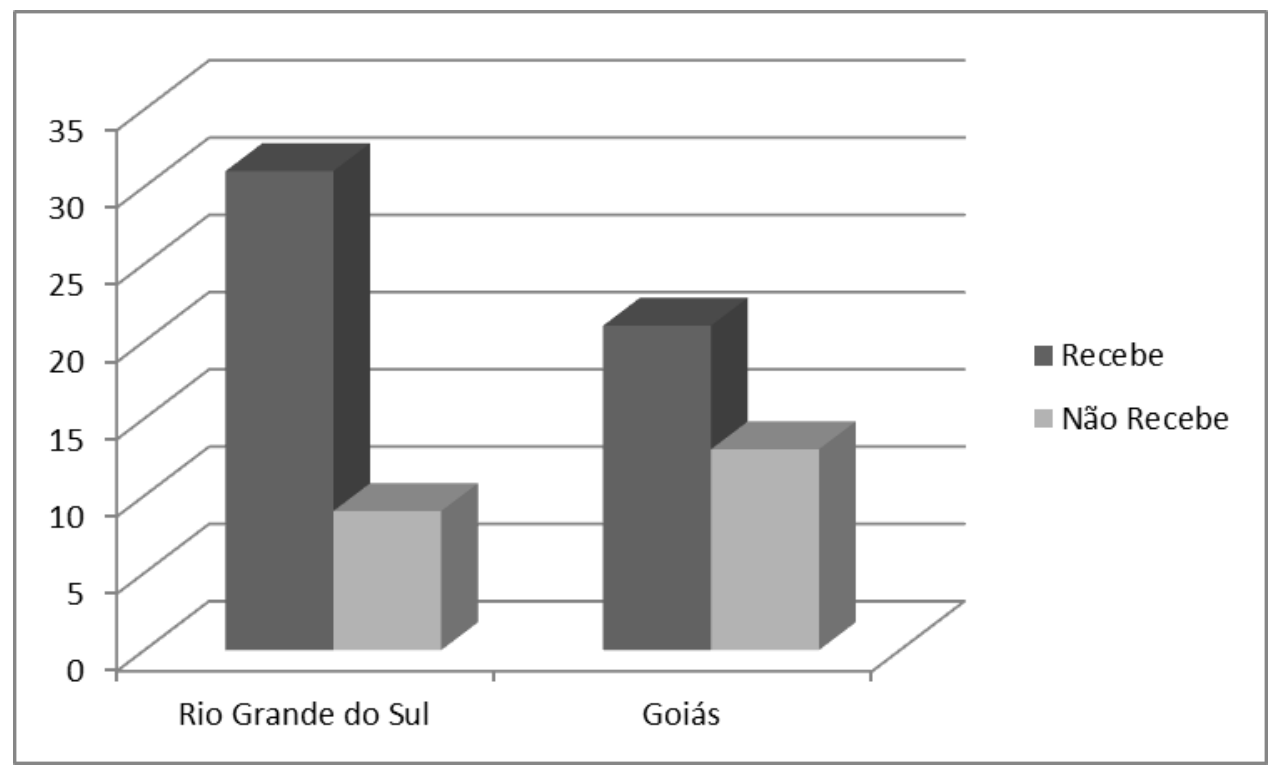

Gráfico 2: Recebimento de informações sobre a Embrapa e/ou suas tecnologias.

No Rio Grande do Sul, 88\% (30) dos entrevistados recebem informações sobre a Embrapa e suas tecnologias pela Emater, sendo a televisão a principal fonte para aqueles que afirmam receber informações sobre a empresa, por meio, sobretudo, de programas como o Globo Rural, da Rede Globo, considerado a principal fonte. Acreditamos que a diferença das respostas entre os estados se dê de acordo com a relação estabelecida entre os agricultores e a Emater local, pois quase todos os entrevistados gaúchos recebem assistência da Emater, e 94\% (32) dos entrevistados que são assistidos afirmam já ter sido informados pela Emater sobre tecnologias geradas pela Embrapa. Em Goiás, nota-se uma realidade bastante diferente, pois apenas 69\% (23) dos entrevistados dizem contar com algum tipo de assistência com relação às questões agrícolas. Entre esses, 19 agricultores recebem assistência da Emater, que já divulgou as tecnologias da Embrapa para nove deles.

No Rio Grande do Sul, 11 pessoas relataram receber material impresso da Embrapa com frequência, sendo esse de fácil compreensão. Houve ainda pessoas que 
afirmaram que, além da Emater (RS), existem outras instituições como fonte de informação das tecnologias, produtos e eventos da Embrapa, tais como associações de produtores e cooperativas.

Quando perguntados sobre se conheciam os programas de TV (Dia de Campo na TV) e rádio (Prosa Rural) produzidos pela Embrapa, apenas 6\% (2) dos agricultores entrevistados do Rio Grande do Sul e 12\% (4) dos de Goiás afirmaram conhecer o programa Dia de Campo na TV, enquanto apenas uma pessoa no Rio Grande do Sul, correspondendo a 3\% dos entrevistados, disse já ter ouvido o programa Prosa Rural. No Rio Grande do Sul, quatro agricultores afirmaram que já haviam assistido a um programa de televisão que achavam que era da Embrapa, mas que não sabiam o nome. Ainda, nove entrevistados do Rio Grande do Sul relataram conhecer o programa de TV Terra Sul, que é produzido pela Embrapa Clima Temperado, em parceria com a Emater da região. Quando afirmam não conhecer os programas da Embrapa, o programa Globo Rural, da Rede Globo, é citado mais uma vez como fonte de informações preponderante sobre a instituição.

A gente não conhece nenhum programa da Embrapa mesmo. A gente conhece muito da Embrapa pelo Globo Rural. Dentro do Globo Rural, todas as pesquisas são da Embrapa. (Agricultor 29 - RS)

Eu tenho uma imagem muito positiva [da Embrapa] por tudo o que eles fazem, e que a gente vê no Globo Rural, mas de programa deles eu não sei. (Agricultor 24 - Goiás)

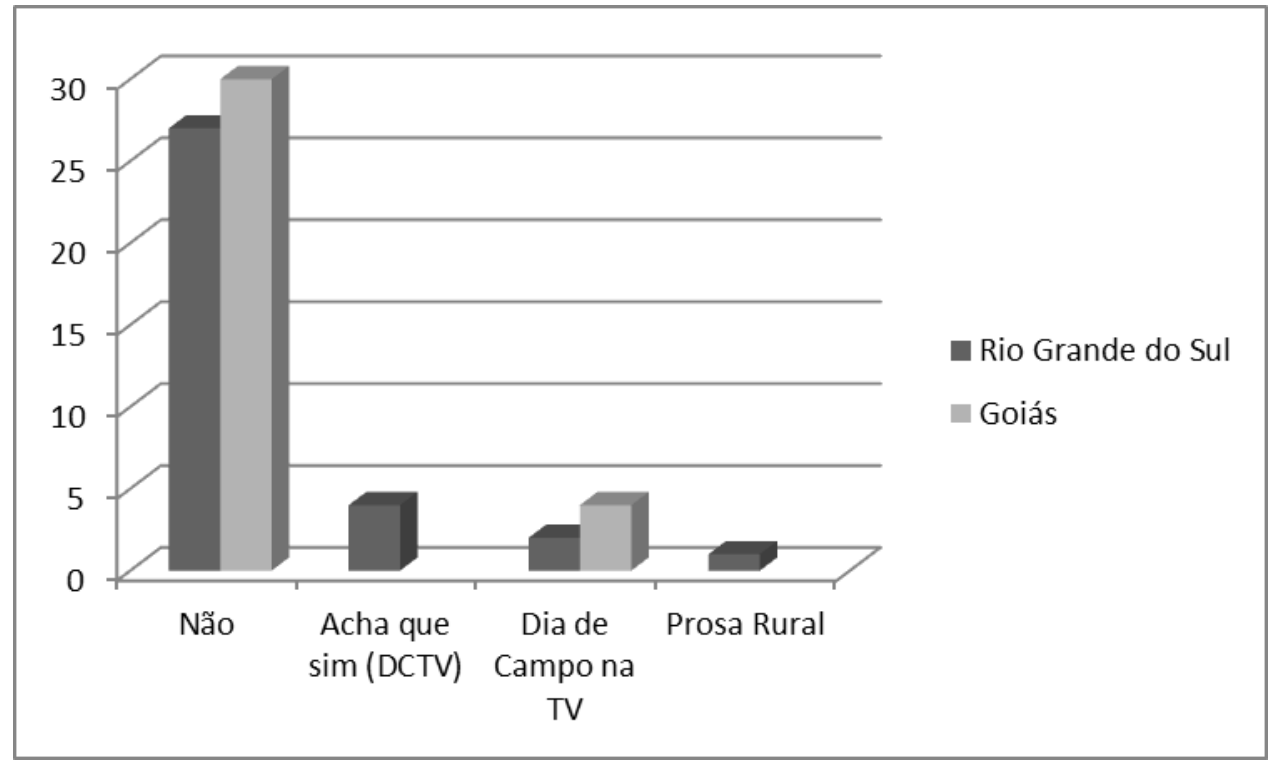

Gráfico 3: Conhecimento sobre os programas de TV e rádio da Embrapa. 
$\checkmark$ Síntese: Tendo a Emater como fonte de informações, os agricultores do Rio Grande do Sul costumam ficar mais informados sobre a Embrapa do que os de Goiás, que têm como principal fonte a televisão. Isso denota claramente o impacto da ação da extensão rural no processo de divulgação e transferência de tecnologia.

\section{2) VISÃO DOS EXTENSIONISTAS}

a) Foco e desenvolvimento de tecnologias pela Embrapa para a agricultura familiar

A maioria dos extensionistas entrevistados acredita que a Embrapa vem desenvolvendo pesquisas para o segmento, voltando-se cada vez mais para esse grupo de agricultores. Apenas um dos 11 entrevistados afirmou que a empresa está mais direcionada para a agricultura de grande escala, em detrimento da agricultura familiar, e que a empresa mantém o mesmo foco desde a sua criação.

Alguns acreditam que atualmente a Embrapa busca se voltar mais para a agricultura familiar em razão da importância que esta representa hoje na produção de alimentos ou nas formas de mobilização do segmento.

Eu tenho a impressão que a Embrapa está muito voltada para a agricultura familiar, não tenho a menor dúvida. Só não sei se é pela importância da agricultura familiar, que representa $70 \%$ do público rural. (Extensionista A - Rio Grande do Sul)

Na Embrapa hoje, queira ou não, $80 \%$ da pesquisa é para a agricultura familiar, porque a agricultura familiar está dominando $80 \%$ da produção de alimentos dentro do país, inclusive para a exportação. (Extensionista $C-$ Goiás)

Acho que no final da década de 1990 para cá começaram a fazer pesquisas mais voltadas para a agricultura familiar [...] deve ter sido alguma mudança de metodologia da própria Embrapa e pela pressão, 
pela cobrança do agricultor familiar, através dos assentamentos que hoje são muito organizados que já vão representando o setor, o movimento. O sindicato vai e consegue fazer uma pressão para fazer uma pesquisa voltada para esse setor, então o que eu vejo é que o pessoal se empoderou mais da Embrapa, antigamente a Embrapa era quase um órgão que ficava lá com os grandes produtores. (Extensionista D-Goiás)

$\checkmark$ Síntese: Entre os extensionistas, chega-se quase ao consenso de que a Embrapa tem como um de seus focos a agricultura familiar e que vem desenvolvendo tecnologias para o segmento.

\section{b) A Comunicação para a transferência de tecnologia para os agricultores familiares}

Quando os extensionistas entrevistados são questionados sobre a comunicação da Embrapa para a transferência de tecnologia voltada para os agricultores familiares, é percebido a existência de um pensamento comum entre os 11 entrevistados, ou seja, a Embrapa não necessita, ou não é seu papel, comunicar-se ou fazer divulgação direta para os agricultores.

Nove extensionistas, cinco de Goiás e quatro do Rio Grande do Sul, disseram que percebem a existência de uma comunicação da Embrapa voltada para a agricultura familiar. Entre esses, dois do Rio Grande do Sul e todos os cinco de Goiás dizem que a comunicação existe, mas que ela chega pouco até os agricultores familiares, ou que precisa ser melhorada.

Eu acho que precisa ser melhorada, se você pegar hoje um agricultor familiar e perguntar o que é a Embrapa talvez ele não saiba dizer o que vem a ser essa instituição, então eu acho que essa comunicação tem que melhorar, da Embrapa para a agricultura familiar. Eu acredito que passa pela Emater e acho que a gente institucionalizando uma parceria facilitaria. (Extensionista B - Goiás) 
Não está tendo uma conversa de perto. Sei porque a gente atende mil produtores aqui e esses que nós andamos hoje ainda utilizam produtos que são resultado de pesquisa da Embrapa e conhecem ela pelos produtos, mas se a gente for em alguns outros produtores, de grão, de leite, de carne, muitos nem conhecem o produto da Embrapa. [...] A comunicação não está boa. Se está pesquisando para o produtor ela tinha que estar 100\% ligada a ele, não é? Do que adianta fazer uma pesquisa que não chega na ponta? (Extensionista C-Goiás)

A Embrapa consegue dizer "estamos aqui", mas ela é distante. [...] A distância é assim: ela chega de menos, a Embrapa chega de menos. (Extensionista C-Rio Grande do Sul)

Um dos entrevistados no Rio Grande do Sul apontou a existência de um bom trabalho de comunicação da Embrapa com os agricultores familiares na região, dizendo ainda que há uma forte participação da Emater nesse processo, enquanto outro entrevistado do mesmo estado, quando perguntado sobre a comunicação da Embrapa com os agricultores familiares, afirmou que levar informação direta para o agricultor não é papel da instituição.

O problema é esse, a Embrapa não tem que levar a informação, ela tem que repassar para que alguém leve. (Extensionista A - Rio Grande do Sul)

Como a formação e a atuação de um dos entrevistados da Emater do Rio Grande do Sul é na área de comunicação, foi perguntado pela pesquisadora se ele sabia da existência de alguma estratégia de comunicação da Embrapa para atingir especificamente o público de agricultores familiares, cuja resposta foi a seguinte:

Eu acho que ainda está um pouco longe, acho que está dependendo das cabeças pensantes mais acima poderem determinar isso de que se deve trabalhar a comunicação com agricultura familiar, eu não vejo uma ação institucional no sentido de uma aproximação, tem todo um discurso mas efetivamente a gente não vê. (Extensionista D - Rio Grande do Sul) 
$\checkmark$ Sintese: Há um pensamento comum entre os extensionistas de que não é papel da Embrapa fazer comunicação ou divulgação direta para os agricultores, sendo a extensão responsável por fazer essa "ponte”. Observa-se entre eles uma percepção de que existem movimentos da Embrapa no sentido de tentar se comunicar com os agricultores familiares, mas ainda inexpressivos ou não adequados.

\section{c) A relação estabelecida entre a Embrapa e a extensão rural}

Quando o tema da relação estabelecida entre Embrapa e a extensão rural é levado para os extensionistas entrevistados, fica claro o entendimento, entre todos, da necessidade de um trabalho conjunto entre Embrapa e, neste caso, a Emater. Segundo eles, a extensão rural tem o papel primordial de ser um agente de desenvolvimento rural, podendo funcionar como um excelente meio de levar as tecnologias da Embrapa até os agricultores familiares, principal público atendido pela extensão rural pública no país.

É nítida a ideia básica que todos os extensionistas, de modo unânime, têm sobre a Embrapa. Ela é considerada uma empresa parceira e com a qual a Emater já mantém uma relação tradicional. No entanto, foi possível verificar que, mesmo que se tenha a visão de instituições parceiras, há uma representativa sensação de desarticulação entre elas, o que fica mais claro entre os extensionistas goianos. Verificou-se também que para nove dos 11 entrevistados a relação não se desenvolve plenamente em âmbitos institucionais como deveria ser, e que as boas relações existentes entre Emater e Embrapa estão ligadas as pessoas que fazem parte de ambas as instituições e que interagem entre si.

Eu acho que a relação vai muito pelas relações pessoais, que acaba o técnico tendo com o pesquisador, mas sempre teve e sempre foi importante, sempre foi grande o envolvimento das duas instituições. (Extensionista E - Rio Grande do Sul)

Eu acho que hoje nós temos uma separação. É uma parceria excelente. Fazemos coisas juntos, mas institucionalmente acho que nós estamos bem separados. Acho que isso é uma coisa que deveria ser revista. [...] Não só da Embrapa, mas no geral as instituições são assim. Elas são 
puxadas mais pela amizade pessoal dos seus integrantes do que pela própria instituição. (Extensionista C - Rio Grande do Sul)

Eu entendo que o acesso que a gente tem à Embrapa às vezes é mais pessoal do que institucional, então eu acho que deveria ser uma parceria institucionalizada. Os centros de pesquisa no país como um todo deveriam institucionalizar essa parceria com as empresas de Ater [Serviço de Assistência Técnica e Extensão Rural], porque quem vai ganhar é o produtor rural. Seria a soma de esforços de duas instituições que teríam uma parceria institucionalizada. (Extensionista B - Goiás)

As relações pessoais entre as equipes parecem ser o elemento que, em algumas situações, ajuda a facilitar a realização de diversas ações e que muitos avanços acontecem a partir das empatias pessoais que estimulam a boa vontade e a colaboração entre os colegas de ambas as instituições. Porém, cinco entrevistados, dois do Rio Grande do Sul e três de Goiás, disseram que essa situação é ruim na medida em que as pessoas mudam e que os trabalhos precisam ter continuidade. Ainda foi apontado, por um dos extensionistas entrevistados, o outro lado da moeda, ou seja, que as relações e as visões pessoais também interferem, de modo negativo, inclusive em âmbito políticogerencial e que isso impacta fortemente na relação entre as duas instituições.

Sempre tiveram épocas, em função de definições políticas da empresa, ou daqui ou da própria Embrapa, que acabou tendo um distanciamento um pouco maior ou mais aproximação. Agora a gente tá vivendo um momento de grande aproximação. Isso depende um pouco das pessoas que estão gerenciando as coisas. Então tem gente que não concorda com alguma coisa da outra pessoa, que é diretor do outro lado, e aí acabam se afastando. A gente viveu isso em alguns momentos. Eu acho que isso é muito ruim. (Extensionista E - Rio Grande do Sul)

Outro ponto que foi abordado por cinco dos entrevistados, três de Goiás e dois do Rio Grande do Sul, é a relação determinada por demanda, em que normalmente os contatos são estabelecidos a partir de ações específicas ou em situações pontuais, tais 
como a realização de um evento, atividade de algum projeto de pesquisa, ou mesmo para consultas sobre algum tema.

É necessário esclarecer que em Goiás a Emater também realiza pesquisa, por causa da incorporação da Empresa Goiana de Pesquisa Agropecuária (Emgopa), em 1996, à instituição. Dessa forma, a relação com a Embrapa pode ser estabelecida de uma maneira diferente do que no Rio Grande do Sul, em que a Emater não tem a atribuição de realizar pesquisa agropecuária. Em Goiás, a Emater é, além de responsável pela extensão rural, geradora de tecnologias, possivelmente desenvolvendo alguns projetos com temas semelhantes aos pesquisados pela Embrapa, fazendo com que seja suscitado um relacionamento menos articulado ou até mesmo certa concorrência entre as instituições. Tal como identificado no seguinte depoimento, que se refere a ações conjuntas na área de pesquisa:

Quando eu sou cliente da Embrapa, com as coisas da Embrapa, a relação é muito boa. Quando eu produzo em conjunto com ela, é muito difícil. As negociações são difíceis. [...] A Embrapa é imprescindível e não é isso que se está discutindo, deixando isso claro, mas as relações não são fáceis porque é uma relação concorrencial mesmo. (Extensionista E-Goiás)

$\checkmark$ Síntese: A percepção da necessidade de um trabalho conjunto entre as duas instituições é unânime, como também a relação de parceria há muito tempo estabelecida entre ambas. Entretanto, foi sinalizada também uma relação desarticulada entre a Embrapa e a Emater de Goiás. De forma geral, a relação é vista como mais personalizada do que institucionalizada, como também pautada por demandas pontuais.

\section{d) A comunicação da Embrapa com a extensão rural}

Em relação à comunicação da Embrapa com a extensão, foi detectado, quase que de forma unânime, que os extensionistas gaúchos têm uma visão mais favorável, afirmando que ela acontece ou que percebem movimentos nesse sentido. Um único entrevistado no Rio Grande do Sul relatou que a comunicação não funciona e atribuiu essa condição ao fato de a relação não ser institucionalizada entre as duas instituições. Os quatro restantes 
apontaram que ela existe, mas poderia ser melhor, indicando que ambas as instituições deveriam estar comprometidas em estabelecer um processo comunicacional que fluísse adequadamente.

Eu acho que a comunicação funciona. Eu não acompanho em todas as áreas, mas a gente tem criado momentos em parceria. A Embrapa propõe, às vezes, e outras a Emater propõe momentos de troca de experiência para que a gente consiga acompanhar a evolução das coisas. (Extensionista E - Rio Grande do Sul)

Acho que isso é uma das coisas que talvez devesse ser melhorada. Eu não sei te dizer, mas acho que até por parte da gente ela se torna mais interessante e mais eficiente quando há procura dos dois lados. Eu acho que, por exemplo, a extensão também tem que procurar se comunicar com a Embrapa. (Extensionista C - Rio Grande do Sul)

Em Goiás todos os extensionistas entrevistados disseram perceber entraves na comunicação entre a Embrapa e a extensão rural e que essa não acontece de forma planejada e nem em fluxo contínuo.

A comunicação é mínima. Eventualmente surge alguma coisa e aí colocam na intranet, mas é bem pouco, uma ou duas vezes por ano. Não tem um jornal, uma revista ou uma comunicação por e-mail que pudesse chegar a todos. Às vezes a gente vai a um evento que a Embrapa está promovendo e recolhe fôlderes revistas e publicações e leva. Mas, quando a gente leva uma quantidade pequena, não é suficiente para a atender o público. (Extensionista D-Goiás)

A gente não tem uma coisa frequente, um mecanismo e um meio que essa comunicação chegue, que essa tecnologia chegue. A gente não tem um caminho traçado. Hoje tudo é muito virtual, se eu acessar o site da Embrapa, seja onde for, eu vou estar vendo as novas tecnologias lançadas, vou ter acesso à literatura, aos boletins técnicos, mas isso é uma coisa que só se eu entrar e buscar. Não tem aquela coisa que veio 
de um roteiro, de um processo institucionalizado para uma nova tecnologia que está chegando da Embrapa para as instituições de Ater. Eu não vejo esse caminho sendo feito. (Extensionista B - Goiás)

Para todos os extensionistas entrevistados, de ambos os estados, a comunicação também parece ser construída a partir de ações pontuais e, sobretudo, pessoais. Segundo eles, mesmo com a inexistência de um canal de comunicação formalizado entre a Emater e a Embrapa, a comunicação flui bem a partir do estabelecimento de relações amistosas e personalizadas entre empregados das duas instituições. Exemplo disso é a relação entre as áreas de comunicação da Embrapa Clima Temperado, no Rio Grande do Sul, e a Emater regional, que há anos produzem em conjunto o programa de TV Terra $\mathrm{Viva}^{25}$. Nesse caso específico, o trabalho é institucionalizado, mas parece acontecer de forma colaborativa e planejada, com uma comunicação direta e frequente. Em Goiás, foi citado um caso onde a comunicação flui adequadamente, mas aparentemente também pautada pelo bom relacionamento entre pessoas de ambas as instituições.

Eu acredito que tem vezes que acontece de os técnicos de extensão irem até a Embrapa e buscar informações, mas tem muitos casos que a Embrapa mesmo liga, marca reunião, marca um dia de campo. (Extensionista A-Goiás)

Quanto questionado sobre a comunicação da Embrapa com a Emater, um dos entrevistados de Goiás chamou atenção para a distribuição de algumas minibibliotecas ${ }^{26}$ em escritórios da Emater da região, que mesmo não sendo uma ação comunicacional propriamente dita, permite que técnicos da extensão, e mesmo agricultores, tenham acesso a publicações da Embrapa, munindo-se de alguma forma esse público com tecnologias, processos e informações geradas pela instituição. Houve ainda no estado um entrevistado que indicou uma nova ação da Embrapa em termos de comunicação

\footnotetext{
25 Programa de TV produzido em parceria entre a Emater e a Embrapa Clima Temperado, desde março de 1993. O programa trata de questões da agropecuária regional, mostrando as ações da extensão rural e a pesquisa agropecuária. Atualmente ele é exibido aos domingos na TV Nativa - Pelotas/RS, afiliada da Rede Record.

26 As minibibliotecas são parte de um projeto da Embrapa e são constituídas por um acervo contendo publicações impressas, a maioria delas cartilhas ilustradas, CDs do programa Prosa Rural e vídeos, com temas sobre preservação e educação ambiental, cidadania, cooperativismo, cultivo de hortas em quintais, criação de pequenos e grandes animais, produção de alimentos de qualidade, manejo de solo e água, ou sobre como iniciar uma pequena agroindústria de alimentos, entre outros.
} 
voltada para transferência de tecnologia, informando que havia participado de eventos promovidos pela instituição, ocasião em que foram discutidos assuntos relativos à comunicação para a transferência de tecnologia, segundo ele, apresentando propostas para ações comunicacionais em conjunto com a extensão.

$\checkmark$ Síntese: A comunicação parece fluir melhor no Rio Grande do Sul do que em Goiás, onde todos os extensionistas entrevistados disseram perceber entraves na comunicação entre a Embrapa e a extensão rural e que essa não acontece de forma planejada e nem em fluxo contínuo. Claramente não existe uma ação planejada de comunicação da Embrapa para a extensão rural, assim como a relação entre as duas instituições, quando ocorre, tem como base também as relações pessoais.

\section{3) VISÃO DA EMBRAPA}

a) Foco e desenvolvimento de tecnologias pela Embrapa para a agricultura familiar

Dentro da Embrapa, foi encontrado, de forma unânime entre todos os entrevistados, um consenso de que a instituição está voltada para a agricultura familiar e desenvolve tecnologias para o segmento, um deles chegou a afirmar que a Embrapa sempre trabalhou com esse público, mesmo antes da nomenclatura agricultura familiar ser adotada no Brasil.

Historicamente, nos trabalhos que a Embrapa sempre fez desde a sua criação, havia um foco muito grande nesse perfil [da agricultura familiar], até porque eles eram a maioria dos produtores, começando pela região Sul, em que a maioria deles era o que nós hoje chamamos de agricultura familiar. Então, o trabalho para desenvolver o cultivo de grãos e desenvolver produção animal no Sul era focado nesse grupo. Ao longo do tempo, com a ampliação de áreas de produção, principalmente para o Centro-Oeste, a Embrapa passou a ter uma atuação mais forte com sistemas e tecnologias que se adaptavam muito bem a sistemas de 
escala, só que a Embrapa nunca deixou de fazer trabalhos pensando na pequena produção. (UD $3-T T 1)$

Cinco dos 11 entrevistados da instituição dizem que entendem que atualmente a agricultura familiar é vista como de grande importância para o país e alvo de diversas políticas de governo, e que essa situação produz reflexos diretamente na Embrapa, que como empresa pública, está alinhada com as políticas governamentais como fica explícito nas falas a seguir:

A gente não pode esquecer que trabalhamos em uma empresa pública e, portanto, ela não é desvinculada das políticas governamentais. [...] Há pressão externa, sociedade, movimentos sociais do campo, políticas públicas, para que a Embrapa, como empresa pública de pesquisa, dê resposta para esse segmento importante na agricultura brasileira. Hoje, a gente tem uma realidade que se espraia. Dizer que hoje a Embrapa não trabalha com a agricultura familiar não é mais uma verdade. A Embrapa trabalha sim. Ela ampliou bastante, muitíssimo, tanto em termos de recurso, quanto em termos de projetos, como em termos de pessoal, pesquisadores e analistas. As Unidades todas têm proposta e estão trabalhando nessa linha. (UD 1 - Com1)

A Embrapa, por ser uma empresa pública, segue necessariamente diretrizes governamentais, e o governo tem demonstrado, já há algum tempo, que é necessário dar uma atenção maior para esse público [da agricultura familiar]. [...] Nós somos um braço da política pública, somos um braço do Estado, então precisamos dar uma atenção maior para a agricultura familiar, ajudando para que essas famílias possam ter uma chance de continuar na agricultura, tendo, talvez, uma vida como elas gostariam de ter. (UD 3 - TT1)

Acreditamos que haja discordância dentro da Embrapa sobre os tipos de tecnologias e a maneira como elas devem ser geradas e também adotadas pela agricultura familiar, visto que foram identificados, entre dois entrevistados da instituição, conflitos acerca da necessidade da tecnologia ser produzida especificamente 
para o segmento, respeitando todas as características e limitações da agricultura familiar, ou adaptada a partir da utilização de tecnologias já existentes, que não tenham sido geradas necessariamente para atender esses agricultores.

Há, ainda, outros três entrevistados que entendem que a questão da adoção, ou não, de um modelo exclusivo de geração de tecnologia para o segmento deve ser muito bem pensada, mas acreditam que a maior dificuldade é, de fato, fazer com que qualquer inovação chegue a esses agricultores, tanto por conta de um modelo inadequado de transferência de tecnologia, quanto pelo sensível enfraquecimento da extensão rural no país.

A Embrapa tem um estoque de tecnologias, tecnologias sociais $e$ tecnologias aplicadas a pequenas agriculturas que vai de A a Z, em todos os segmentos do Brasil, como a gente fala: do Oiapoque ao Chuí, em todas as dimensões do Brasil. Agora o desafio é fazer chegar, mas chegar nessa forma mais compartilhada que a gente tem insistido, não basta ter solução de prateleira, aquilo de que você pega uma solução na prateleira, entrega para o agricultor e está feito o trabalho da Embrapa. Não é isso, tem que participar de modelos de desenvolvimento local, muitas vezes não é só o gargalo tecnológico que vai resolver o problema da agricultura familiar daquele estado, depende de uma série de outros fatores. (Sede-TT1)

Eu não acho que falta fazer coisas para eles [agricultores familiares]. Talvez falte falar melhor para eles o que a gente faz. Esclarecer isso, nós temos sim. Historicamente a gente fez, sim, só que chegou mais fácil para o grande do que para o pequeno, [...] os grandes, que têm recursos, tinham condições de contratar os seus agrônomos, a sua assistência particular, as suas cooperativas mais fortalecidas e por isso tiveram acesso mais facilitado à tecnologia da Embrapa, enquanto o pequeno produtor se viu órfão de assistência técnica pública e ficou sem conhecer, sem o intermediário que fazia ponte com a Embrapa. (SedeCom1) 
$\checkmark$ Síntese: Entre os empregados da Embrapa entrevistados, é unânime o entendimento de que a instituição está voltada para a agricultura familiar e desenvolve tecnologias para o segmento.

\section{b) A comunicação para a transferência de tecnologia voltada para os agricultores familiares}

Quando é abordada especificamente a comunicação para a transferência de tecnologia, como recurso de relacionamento com agricultura familiar, todos os entrevistados da Embrapa, com atuação na Sede da empresa, disseram que ainda não existe um planejamento corporativo para atender esse público especificamente. A totalidade dos entrevistados ligados à área de transferência de tecnologia informou a existência de ações em construção e processos que ainda estão sendo discutidos para que sejam adequados para o perfil desse público. Ainda na Sede, não foi apontada nenhuma estratégia exclusiva para esse público pelos entrevistados ligados à área de comunicação, mas foi dito por um deles que existem ações que podem atender esse público em projetos de pesquisa ligados ao Macroprograma ${ }^{27}$ 6, mas que ações planejadas com esse foco dentro da área de comunicação corporativa não existem.

Todos os cinco entrevistados da Sede apontaram o programa de rádio Prosa Rural como uma ação pontual de comunicação da Embrapa voltada especificamente para o público da agricultura familiar, enquanto nas Unidades apenas um dos entrevistados fez referência ao programa, indicando que esse não estaria adequado para atender às diferenças regionais da agricultura familiar:

A Embrapa tem algumas iniciativas de caráter corporativo institucional que unificam do Oiapoque ao Chuí. Um exemplo é o programa Prosa Rural, que é um instrumento interessante, mas que nem todo agricultor familiar vai utilizar [...]. Às vezes, a fonte de informação passa a ser diferente de um para outro e aí a gente acaba não considerando isso

\footnotetext{
${ }^{27}$ Como já explicado anteriormente, são programas que orientam a gestão das carteiras de projetos e processos da Embrapa. Em número de seis, cada Macroprograma possui projetos, financiamento e formas de indução de projetos específicos, que atuam como instrumentos para cumprimento de metas técnicas. O Macroprograma 6 é exclusivo para submissão de projetos voltados para a agricultura familiar. Informação disponível em <https:intranet4.sede.embrapa.br〉. Acesso em: 31 out. 2013
} 
porque usamos uma estratégia corporativa e, quando é corporativo, não se considera as diferenças regionais. (UD3-TT1)

Nas Unidades as ações voltadas para os agricultores familiares costumam acontecer de forma planejada entre as áreas de comunicação e transferência de tecnologia, mas muitas, conforme apontado por um dos entrevistados, vão acontecendo no que ele chamou de "piloto automático".

Sete dos onze entrevistados, entre Sede e Unidades, disseram ser necessária uma comunicação diferenciada para atender ao segmento de agricultores familiares, conforme as falas a seguir:

Tem que ser diferenciada, eu acho que para a agricultura familiar é aquela coisa, nós precisamos criar canais de "menos para, e mais com a agricultura familiar”. Então muitas vezes os canais institucionais da Embrapa de relacionamento ou de comunicação para esse público é para esse público, isso é disponibilizar informações, mas por isso só não é que está errado. Faz parte do processo, mas precisa ser mais do que isso. Precisamos criar canais mais horizontais com a agricultura familiar, então não basta você fazer canais informativos, informando que existe determinada tecnologia, você tem que criar canais de relacionamento, e relacionamento é uma coisa muito maior, e muitas vezes é isso criar ambientes de relacionamento, criar espaços onde os setores se encontram. (Sede - TT1)

Nosso jeito de comunicar historicamente é um só, e nós achamos que só esse jeito resolve todos os problemas. É mais ou menos o discurso que falava na pesquisa: "ah, a tecnologia gerada pela Embrapa atende a todos os públicos, então ela serve desde um cara de meio hectare até um cara de 50 mil hectares". Mais ou menos, se o nosso jeito de comunicar é igual para todo mundo, nós achamos que vai servir para todos, mas sabemos que na prática as demandas são diferentes. Então a Embrapa historicamente não tem dado uma atenção diferenciada para a agricultura familiar, ela poderia evoluir mais, eu acho que ela precisa pensar um pouco mais em como focar melhor essa comunicação para 
esse público. Existe um passivo e eu acho que a Embrapa precisa trabalhar nisso. (UD3-TT1)

Em uma das Unidades de pesquisa onde foram realizadas entrevistas, identificamos a existência de algumas ações de comunicação para a transferência de tecnologia para os agricultores familiares, que são institucionalizadas apenas no âmbito dessa Unidade.

Nós temos um programa de TV feito em parceria com a Emater. Temos também programas de rádio em parceria com a Emater e com o sindicato dos trabalhadores rurais, e todos os agricultores escutam aquele programa. Então aquele que não tem youtube em casa escuta rádio, muitas notícias são colocadas no Facebook, muitos filhos de agricultores acessam o Facebook, enviamos mensagem por celular. Eu acho que a gente tem buscado chegar de diferentes formas, mas ainda temos muito que avançar. (UD2 - TT2)

$\checkmark$ Síntese: Não existe um planejamento corporativo de comunicação para a transferência de tecnologia para atender especificamente a agricultura familiar. Nas Unidades, existem ações voltadas para o segmento que são planejadas em conjunto entre as áreas de comunicação e transferência de tecnologia. Há um entendimento sobre a necessidade de uma comunicação diferenciada para os agricultores familiares.

\section{c) A relação estabelecida entre a Embrapa e a extensão rural}

A relação da Embrapa com a extensão rural é abordada de forma distinta entre os entrevistados lotados na Sede da empresa e os lotados nas Unidades de pesquisa ou serviço. A relação existente entre os órgãos de extensão rural e as Unidades de pesquisa é muito mais próxima, existindo contato direto entre ambos. Assim, as respostas encontradas entre os entrevistados da Sede da Embrapa estão relacionadas à extensão rural de forma geral, enquanto nos centros de pesquisa e na Unidade de serviço algumas 
respostas se vinculam à relação com a extensão rural do estado onde o centro está localizado.

\section{$\underline{\text { Embrapa (Sede) }}$}

$\mathrm{Na}$ Sede da Embrapa, os dois respondentes ligados à comunicação apresentaram uma percepção semelhante, mas, segundo eles, embasada no resultado da pesquisa de imagem realizada pela Embrapa entre 2011 e 2012.

Ambos apontaram que a Embrapa tem muito a avançar com relação à extensão rural e que hoje a empresa está um pouco distante dos órgãos responsáveis pela sua execução no país.

A gente fez uma pesquisa de imagem, que foi concluída em 2012, que nos deu sinais claríssimos de que nós temos muito a avançar com a assistência técnica, com a Emater, com cooperativas, com todos esses órgãos que estão externos à Embrapa e voltados para os interesses do agricultor, vamos dizer assim. A pesquisa de imagem [...], que entrevistou muitos desses parceiros nossos, nos disse claramente que eles têm um entendimento de que a Embrapa não está tão presente com eles como está com outros públicos e que a Embrapa deveria estar mais presente com eles, deveria acompanhar mais a realidade deles, abrir mais a discussão, fortalecer o relacionamento. (Sede - Com1)

Ainda sobre a relação estabelecida entre a empresa e a extensão rural, os mesmos entrevistados chamaram atenção para a sua percepção de que a Embrapa, quando realiza ações em parceria com alguma instituição de extensão rural, como a Emater, por exemplo, coloca-se como protagonista, criando certo desconforto na relação estabelecida entre as duas instituições. Mas também foram apontadas iniciativas para reverter essa percepção, por meio de ações de comunicação dando crédito e reconhecimento à contribuição dos parceiros da instituição. Segundo eles, ainda há a necessidade de uma participação da extensão na concepção de projetos de pesquisa.

Os extensionistas têm várias reclamações. Primeiro a de que eles são esquecidos nesse processo, não são valorizados, é só a Embrapa que 
aparece e a nossa marca é muito forte; segundo, eles não são chamados para participar dos projetos de pesquisa da Embrapa, só são chamados quando o produto está quase pronto e aí, às vezes, é tarde demais para fazer qualquer ajuste. (Sede-Com2)

Eu acho que [para melhorar a relação com a extensão rural] a Embrapa precisaria ter de fato os profissionais da assistência técnica com o papel mais fortalecido na estrutura da Embrapa mesmo. Que a gente tivesse fóruns, instrumentos na Embrapa que obrigatoriamente envolvam essas pessoas no momento da definição de projetos, por exemplo. [...] Essa é uma coisa, e a outra, que eu acho que é bem institucional [...], a gente na Secom está tentando mudar muito, que é o protagonismo das coisas, na forma de mostrar o trabalho que a Embrapa, entre aspas, faz. É tentar deixar o nome da Embrapa de lado e tentar sempre falar dos parceiros que estão presentes com a gente. (Sede-Com1)

Entre os três entrevistados ligados à área de transferência de tecnologia da Sede, o consenso foi sobre a necessidade de uma reconstrução de relacionamento com a extensão rural, que, segundo eles, após o desmonte do Sistema Brasileiro de Assistência Técnica e Extensão Rural (Sibrater), no início da década de 1990, ficou bastante fragilizado. Esses entrevistados também indicam que a relação que precisa ser estabelecida entre a Embrapa e a extensão rural deve ter como base uma estrutura mais dialógica, de forma diferente do modelo que vem sendo praticado.

Por mais que existam alguns casos exitosos de extensão rural no país, a maioria não é assim, está tendo muita dificuldade com a extensão rural nos estados. E essa ausência de um órgão nacional de extensão rural de 24 anos é quase $2 / 3$ da história da Embrapa [...], então nós vamos ter que reaprender o que significa relacionar empresa de pesquisa com um órgão de extensão. Isso significa criar novas modalidades de conversação e de estabelecimento de possíveis parcerias, estabelecer um modo de trabalho que seja complementar um ao outro, que um reforce o outro. $($ Sede-TT1) 
Um dos entrevistados também indicou a necessidade de revisão de papéis na relação entre Embrapa e extensão rural, pois hoje existem muitas outras instituições, tais como cooperativas, associações, ONGs, outros órgãos governamentais, que permeiam esse relacionamento e junto com a Embrapa e a extensão rural pública compõem um arranjo de instituições que trabalham, de certa forma, voltadas para o mesmo tipo de público.

Eu acho que hoje está muito mais claro que as instituições vão ter que redefinir os seus papéis. Não é a Embrapa chegando em um ambiente para resolver os seus problemas que ela vira o sol que ilumina aquele lugar. [...] Existe um arranjo de instituições e a Embrapa é mais uma ali, então a Ater [também] é mais um ator ali. (Sede - TT2)

\section{$\underline{\text { Embrapa (Unidades) }}$}

Assim como na Sede, dois entrevistados das Unidades relataram dificuldades no relacionamento entre a pesquisa e a extensão rural pública a partir de um enfraquecimento da extensão no país, como também a existência de movimentos da Embrapa para suprir um espaço por meio de projetos que preveem articulações mais intensas com a extensão rural, chegando a capitanear eventos de capacitação direta a agricultores, por exemplo.

Acho que a Embrapa ainda sente muito a dificuldade que a extensão rural pública tem, porque o jeito da Embrapa de funcionar ainda é muito dependente de uma extensão rural pública forte, atuante, bem estruturada [...]. Nos estados onde a extensão rural pública não é forte, a gente tem bastante dificuldade em chegar ao agricultor. Então é aí quando a gente começa a tentar buscar outros canais, outros meios, tentar não depender apenas do técnico de extensão. [...] Eu acho que a gente passa a ampliar as formas de atuação, o leque de atores com os quais a Embrapa trabalha. No passado, a Embrapa estava numa zona de conforto, bastava ela interagir com a extensão rural e tudo estava resolvido. Isso deixou de ser realidade. (UD 3 - TT1) 
O sistema Embrater foi desmantelado no governo Collor e por conta disso ficou um vácuo, um hiato, e a Embrapa vem tentando suprir esse hiato. Ainda que não esteja lá na sua missão final fazer isso, mas ela vem tentando suprir [...]. Trabalhar em conjunto e capacitar a extensão rural para atuar com o agricultor. (UD 1 - Com 1$)$

Também foi verificada entre quatro dos seis entrevistados nas Unidades a percepção de que a existência em determinados estados de uma extensão fortalecida proporciona uma relação mais promissora entre Embrapa e a Ater local. Assim, cabe salientar que dentre as Unidades pesquisadas, uma está localizada em uma região que mostra indícios de uma extensão bastante atuante e forte, fator parece, de fato, impactar na relação estabelecida entre a extensão rural e a Embrapa, como Unidade.

Nós temos uma relação visceral com a Emater desde os anos 1980, em que muitos pesquisadores e extensionistas desenvolvem processos de pesquisa e desenvolvimento e validação de tecnologias juntos. [...] Então eles [os extensionistas] têm esse papel de estar lá na ponta abastecendo, mas, por outro lado, ao estar no meio real onde as coisas acontecem, eles têm capacidade de ver coisas novas, de trazer novos temas para que a gente possa trabalhar na pauta da pesquisa. É uma relação dialógica de complementariedade e que nos ajuda muito no processo da pesquisa, de formatação de projeto de pesquisa, mas também nos ajuda no processo de disponibilização de tecnologia. (UD2 - TT1)

Na nossa Unidade eu ainda não vejo muito trabalho com a extensão privada. A gente trabalha mais com a extensão pública e esse trabalho tem sido muito bom. A gente tem feito muita coisa em parceria com a Emater e, como todo trabalho de parceria, de vez em quando a gente tem que dar uma ajustada, mas eu vejo de uma forma muito positiva. A Emater tem sido uma parceira nossa em vários aspectos, em termos de comunicação a gente tem trabalhado de forma mais integrada nas coisas que a gente faz também. Eu acho que a gente está num caminho muito legal com a Emater daqui. (UD 2 - Com1) 
Um dos entrevistados de Unidade apontou ainda que a relação da Embrapa com a extensão rural não é institucionalizada pela empresa como um todo, e que as relações são construídas de forma particular pelas Unidades.

Ela não é institucionalizada, o que a gente enxerga é que no dia a dia ainda não é uma articulação institucionalizada e, como eu já comentei, a Embrapa é formada por mais de 40 Unidades. Existem Unidades em que a demanda é muito forte então eles trabalham muito integrados, e outras nem tanto. Então, para ser institucional, tem que todas as Unidades da empresa trabalhar de uma forma comum, mas isso não acontece. (UD 1 - Coml)

Oito dos 11 entrevistados da Embrapa (Sede e Unidades) revelaram uma grande expectativa de mudanças positivas na relação da Embrapa com a extensão rural a partir da criação da Agência Nacional de Assistência Técnica e Extensão Rural (Anater) ${ }^{28}$.

[...] a gente sempre identificou como um gargalo de uma empresa como a Embrapa fazer chegar as soluções no campo, faltou sempre essa perna da extensão fortalecida com grandes exceções em alguns estados: Minas Gerais, Rio Grande do Sul, aqui no DF. Em vários estados até tem sido fortalecida. Mas a ausência desse organismo nacional também deixava a Embrapa sem um diálogo concreto, e agora com a criação da Anater esperamos que seja o espaço dessa concertação. (Sede - TT1)

Mesmo não fazendo parte da análise deste trabalho, vale esclarecer ainda sobre a criação da Anater que um dos entrevistados da Embrapa expôs a existência de uma visão crítica por parte de estudiosos da extensão rural acerca da criação da referida Agência e sua vinculação ao Ministério da Agricultura Pecuária e Abastecimento (MAPA) e não ao Ministério do Desenvolvimento Agrário (MDA), como também da participação da Embrapa em sua estrutura gerencial. Segundo ele, para esses estudiosos, a Embrapa está muito focada em tecnologia, que é apenas um componente dentre

\footnotetext{
${ }^{28}$ A Agência, instituída em maio de 2014, é vinculada ao Ministério da Agricultura Pecuária e Abastecimento (MAPA) e conta com a participação de pessoas da Embrapa em sua composição inicial. Tem entre suas competências promover a integração do sistema de pesquisa agropecuária e do sistema de assistência técnica e extensão rural e fomentar o aperfeiçoamento e a geração de novas tecnologias e a sua adoção pelos produtores.
} 
muitos outros que precisam ser trabalhados junto às famílias de agricultores, e que esse fator poderia influenciar negativamente na Agência. ${ }^{29}$

$\checkmark$ Síntese: Corporativamente, foi observado que há certo distanciamento entre a Embrapa e a extensão rural, como ainda fragilidades no relacionamento, mas há na Embrapa indicações de movimentos para melhorar a relação, principalmente por meio da abertura de diálogos. Assim como na Sede, nas Unidades também são percebidas dificuldades no relacionamento entre a pesquisa e a extensão, principalmente a partir de um enfraquecimento da extensão rural no país.

\section{d) A comunicação da Embrapa com a extensão rural}

Quanto à comunicação da Embrapa com a extensão, não foram apontadas pelos entrevistados da própria Embrapa estratégias de atuação institucionalizadas ou formais, mas sim algumas ações pontuais e cotidianas, tais como organização conjunta de eventos ou elaboração de peças comunicacionais específicas, principalmente no âmbito das Unidades.

De acordo com todos os profissionais entrevistados da Sede da área de transferência de tecnologia, a Embrapa, pautada pela criação da Anater, está planejando ações que visam ao estabelecimento de uma comunicação estratégica com a extensão rural como um todo. Para isso, já estão sendo realizados eventos de concertação que contam com a participação de representantes das empresas estaduais de extensão rural em que são discutidas, entre outros assuntos, formas institucionalizadas de relacionamento entre as duas instituições.

$\checkmark$ Síntese: Não há na Embrapa um planejamento de uma prática comunicativa integrada e voltada especificamente para a extensão rural.

\section{e) A transferência de tecnologia como papel da Embrapa}

\footnotetext{
29 Também foi encontrado entre os entrevistados da extensão rural dúvidas acerca da criação da Anater, tais como o formato que a agência vai ter, como será a sua relação com as empresas estaduais de extensão rural ou se ela ainda será responsável por coordenar e também fomentar as ações da extensão rural no país como um todo. De forma geral, percebemos nos extensionistas um desconhecimento quase que total do papel que a Agência deve desempenhar.
} 
Internamente, na Embrapa, encontram-se posições diferentes acerca do papel da instituição com relação à transferência de tecnologia. A ocorrência de opiniões contrárias acontece a partir da questão que se refere a ser, ou não, papel da instituição fazer transferência de tecnologia, sendo que posições divergentes sobre esse tema convivem dentro da Embrapa há tempos. Entre os entrevistados, encontrou-se um consenso sobre essa questão, visto que todos os respondentes, tanto na Sede quanto nas Unidades, disseram que a transferência de tecnologia e a pesquisa fazem parte de um mesmo processo, entendendo que a transferência também é papel da Embrapa.

Nós vemos aqui, e também temos observado na prática, que o processo de transferência e o processo de geração de conhecimento são um único processo, não são dois processos. Primeiro, ele não é desassociado e ele não pode ser separado. De forma que não existiria justificativa para que existisse uma pesquisa que ficasse enclausurada, que ficasse lá emprateleirada, que ficasse sem uso, que seria facilmente provado como um desperdício de dinheiro público, especialmente numa empresa como a Embrapa. (Sede-TT3)

Olha, o papel da Embrapa é fazer pesquisa e também, a meu ver, transferência de tecnologia. Porque não há sentido em uma empresa pública, que depende de recursos públicos, não devolver os resultados do seu trabalho para a sociedade e para aqueles que mais precisam: o usuário, o produtor, principalmente aqueles que são desprovidos de recursos tecnológicos, financeiros etc. Então o papel, a Embrapa, 41 anos após a sua criação, ela toma consciência que não é mais uma empresa só de pesquisa. Ela é uma empresa de pesquisa, de desenvolvimento, de transferência, de intercâmbio de conhecimento e de construção de novos conhecimentos. (UD 1 -Com1)

Nós entendemos que o processo de pesquisa e de transferência de tecnologia não são coisas dissociadas, é um continuum. Não existe um sentido linear da pesquisa para a transferência, muitas vezes transferência vem antes da pesquisa porque num processo de comunicação de interpretação do fato social pode se identificar 
demandas para novos projetos. É uma coisa muito mais de diálogo, de intercâmbio. Então nós aqui na nossa Unidade, pelo menos, trabalhamos na perspectiva de que a nossa Unidade trabalha como um agente do desenvolvimento, e o agente de desenvolvimento tem que ter tarefa, sim, de trabalhar na fronteira do conhecimento, porque é uma instituição de pesquisa e também tem que ter formas de democratizar esse conhecimento da forma mais plural possível. (UD 2 - TT1)

Ainda com relação à transferência de tecnologia ser papel ou não da Embrapa, dois entrevistados, um da Sede e outro de uma Unidade, deixaram clara a sua percepção de que mesmo sendo papel da instituição fazer a transferência da tecnologia por ela gerada, essa não tem que acontecer diretamente para o usuário final, sendo a extensão rural o intermediário nesse processo.

No mínimo, a preocupação de conversar com o intermediário, que é a assistência técnica, precisa ser da pesquisa. Nós não temos como fazer a tecnologia e esperar que o produtor ou a assistência técnica venha buscar assim espontaneamente, até porque muitas vezes eles não sabem o que a gente está fazendo, porque muitas vezes a gente não só atende à demanda, a gente cria coisas que as pessoas não estão sabendo que aquilo é uma possibilidade. Então, acho que é quase matemática a necessidade de a pesquisa se preocupar com a transferência. Mas, que fique claro, na minha concepção transferência não significa, no âmbito da Embrapa, a chegada da tecnologia para o produtor, o usuário final. Para mim, transferência de tecnologia significa a chegada da tecnologia para o público intermediário, porque é esse público intermediário: assistência técnica, extensão rural, que tem a linguagem, o preparo técnico para ir a campo e fazer o repasse da tecnologia. (Sede-Com1)

Supostamente a pesquisa feita é fruto de uma demanda, de um problema identificado, uma necessidade identificada, então se a pesquisa ficar apenas em um artigo publicado em um periódico internacional o resultado da pesquisa não resolveu o problema no setor produtivo que é a razão pela qual a pesquisa foi executada, precisa haver essa ponte. 
[...] mas não necessariamente com a Embrapa interagindo diretamente com os agricultores. A Embrapa tem que assegurar que junto com os outros atores, que fazem esse papel junto aos agricultores, [...] a Embrapa tem que assegurar que os seus resultados cheguem lá. (UD 3 TT1)

$\checkmark$ Síntese: Existe o entendimento de que a transferência de tecnologia e a pesquisa fazem parte de um mesmo processo, ou seja: a transferência também é papel da Embrapa. Mas também é entendido que não necessariamente a Embrapa tenha que fazer transferência direta para os agricultores.

\section{f) A importância atribuída pela Embrapa à transferência de tecnologia}

\section{$\underline{\text { Embrapa (Sede) }}$}

Perguntados sobre a importância atual da transferência de tecnologia para a Embrapa, os entrevistados da Sede disseram perceber um movimento interno na tentativa de fortalecimento da área na instituição. Quatro dos cinco entrevistados apontaram a criação da Diretoria de Transferência de Tecnologia, em 2009, e do Departamento de Transferência de Tecnologia (DTT) como um grande passo nesse sentido.

A importância [da transferência de tecnologia] vem sendo construída, a Diretoria de Transferência foi criada em 2009, o Departamento, em 2010. Então já é uma sinalização de que a transferência de tecnologia é importante dentro da empresa. Hoje a nossa direção fala no processo de produção na Embrapa, não só a pesquisa, mas a pesquisa e a transferência de tecnologia integradas em um mesmo processo de inovação. Então ela vem ganhando corpo dentro da Embrapa, com a criação da diretoria e do departamento ela cria um locus, um espaço de discussão das metodologias de transferência de tecnologia e que tipo de transferência de tecnologia se requer hoje nesse ambiente produtivo da agricultura brasileira. (Sede-TT1) 
Para um dos entrevistados, mesmo com esse movimento de fortalecimento, há uma grande diferença de importância entre as áreas de pesquisa e transferência de tecnologia, e que devido ao DNA da empresa, ou seja, sua origem e constituição, ser de pesquisa, a transferência de tecnologia é sempre vista como uma área de menor valor. Para ele, somente uma real equiparação entre as áreas poderia efetivar o processo de inovação ${ }^{30}$.

Acho que a transferência de tecnologia sempre foi relegada a um nível menor dentro da empresa, por essa matriz, esse DNA de pesquisa da Embrapa [...]. Isso é uma coisa que durante um tempo fez parte desse ideário da instituição. [...] Para efetivar inovação, você tem que entrar em um contexto específico, tem que estar adaptado às necessidades para dinamizar esse processo produtivo. Então, hoje a transferência de tecnologia tem assumido esse papel. De alguma forma, para efetivar a inovação, acho que até é uma questão institucional que está posta, mas que talvez não esteja sendo conduzida tão fortemente ainda. Você tem que colocar transferência de tecnologia no mesmo nível que a pesquisa como solução efetiva para a inovação. (Sede - DTT2)

Foi apontado por um dos entrevistados que, mesmo com mudanças ocorrendo e um visível fortalecimento da área de transferência de tecnologia, existe pouco resultado desse processo refletindo externamente, ou seja: junto ao público a quem se destinam as ações de transferência.

É lógico que todas essas mudanças, a criação de uma diretoria focada em transferência de tecnologia, a criação de um departamento focado nisso, dentro da comunicação, uma área mais voltada para isso, lógico que isso já são indícios reais de que mudanças aconteceram na Embrapa. A crítica que faço é que essas mudanças foram promovidas desde 2010, a gente tem quatro anos de mudanças, e pouquíssimos resultados efetivos conseguiram ser vistos lá fora. Então, internamente a gente tem desafios enormes para se trabalhar, a gente não conseguiu

\footnotetext{
${ }^{30}$ Para a Embrapa, a inovação só acontece na medida em que uma determinada tecnologia gerada é adotada.
} 
evoluir de forma rápida nisso, os passos que estão sendo dados [...] ainda são muito tímidos do ponto de vista de impactar mudanças na sociedade. (Sede-Com2)

O mesmo entrevistado afirmou também que as mudanças e os novos caminhos da área de transferência de tecnologia ainda não são de conhecimento ou não foram apropriados pelas Unidades e que há uma falta de sistematização ou uma burocratização corporativa que torna esse processo moroso, impactando nas Unidades, que permanecem fazendo seus trabalhos de transferência de tecnologia de forma independente das diretrizes corporativas.

Primeiro, esse projeto [de uma nova proposta de transferência de tecnologia] não foi desembrulhado de forma efetiva em todos os centros de pesquisa da Embrapa. Então mesmo lá na ponta, nas Unidades, ainda há um desconhecimento sobre as prioridades, os novos rumos dessa transferência de tecnologia. A política de transferência desde 2010 está sendo construída e até hoje não saiu uma agenda estratégica com prioridades para construir tecnologia, não está devidamente sistematizada e compreendida por todas as equipes de TT, e ainda bem que as Unidades ainda estão trabalhando separadamente. Se elas estivessem esperando essas prioridades e diretrizes saírem da Sede da Embrapa, nós estaríamos perdidos. (Sede-Com2)

Ele também chamou atenção para a existência de diferentes formas de trabalhar a transferência de tecnologia pelas Unidades. Cada uma tratando essa questão de forma própria, sendo que algumas conseguem realizar um excelente trabalho de transferência, com resultados muito positivos junto ao público, tanto de técnicos de extensão rural quanto de agricultores, enquanto outras não conseguem desempenhar esse papel da mesma maneira.

\section{$\underline{\text { Embrapa (Unidades) }}$}

Assim como nas entrevistas realizadas na Sede da Embrapa, também nas Unidades foi percebido que existe uma concordância, entre todos os entrevistados, com 
relação à importância da transferência de tecnologia para a Embrapa e a necessidade de ela ocupar um papel estratégico dentro da instituição, como também de ser tão valorizada quanto a área de pesquisa.

Primeiro, a transferência de tecnologia deve ocupar papel estratégico e semelhante à pesquisa e ao desenvolvimento. Porque a Embrapa precisa validar os seus resultados, do contrário não tem como avançar no próprio processo da ciência. E como ela valida? Colocando esses resultados para a sociedade, no mercado, para quem vai fazer uso dela. E isso se dá por meio do processo de transferência de tecnologia. Então a TT é um caminho para retroalimentar a pesquisa. Quanto à importância, entendo que TT e pesquisa devam ter o mesmo peso, seja do ponto de vista de pessoal, equipes para trabalhar, seja do ponto de vista de recursos em termo de investimento em projetos, dentro da organização. (UD1-Com1)

Eu acho que [a transferência de tecnologia] é fundamental porque não tem conhecimento sábio que possa permanecer numa prateleira. Por mais sábio que ele possa ser, ele tem que circular, ele tem que ser apropriado por alguém numa sociedade que arca com os custos da produção desse conhecimento. Então eu acho que a transferência tem um papel tão relevante quanto os outros macroprocessos da empresa, processo de desenvolvimento institucional e processo de produção do conhecimento, da pesquisa propriamente dita. (UD 2 - TT1)

Dois entrevistados de Unidades apontaram que entendem que a transferência de tecnologia é de grande importância no processo de pesquisa, desenvolvimento e inovação da Embrapa, mas que na instituição a importância e valorização dessa área são mais discursivas do que práticas.

Hoje existe a diferença entre o que é dito e o que é palpável, o que é percebido no dia a dia. É dito que TT é fundamental, um pilar e não tem como uma Embrapa funcionar sem uma TT atuante. Na prática nós sabemos que TT ainda não tem aquele mesmo grau de importância que 
uma pesquisa tem dentro da empresa, não estou falando o que eu quero que seja, mas o que a gente percebe que acontece. [...] É, eu acho que no discurso a TT é mais importante do que na prática da empresa. (UD 3 TT1)

$\checkmark$ Síntese: Tanto na Sede como nas Unidades há uma concordância entre os entrevistados de que a transferência de tecnologia é importante para a Embrapa e de que deve ocupar um papel estratégico dentro da instituição, necessitando ser tão valorizada quanto a área de pesquisa, já que ambas fazem parte de um mesmo processo, o de inovação. São percebidos movimentos internos para fortalecimento da área dentro da Embrapa.

\section{g) A Comunicação para a transferência de tecnologia no cenário da Embrapa}

\section{$\underline{\text { Embrapa (Sede e Unidades) }}$}

A comunicação foi considerada por todos os entrevistados como essencial para o processo de transferência de tecnologia.

É fundamental. Hoje se você falar em relacionamento você precisa utilizar os instrumentos da comunicação, num Brasil com essas dimensões, com mais de 200 milhões de habitantes [...] Nós não vamos estar cara a cara com todos os agricultores individualmente, então nós precisamos pensar em mecanismos que são as ferramentas da comunicação. Então, comunicação e transferência têm que estar juntas o tempo todo. (Sede-TT1)

A participação da comunicação no processo de transferência de tecnologia é fundamental, a gente não vê transferência sem comunicação. (UD3-TT1)

É fundamental. A comunicação é um instrumento que nos ajuda a dar visibilidade ao nosso trabalho [de transferência de tecnologia] e que faz. com que a apropriação do conhecimento aconteça de forma muito mais 
rápida e participativa..[..] É fundamental que não exista separação entre os processos de comunicação, transferência de tecnologia e pesquisa. (UD2-TT1)

[A importância da comunicação] é muito grande porque ninguém faz. processo de transferência de tecnologia sem comunicar, não é? Você precisa saber como vai chegar nessas pessoas, como vai falar com elas e também como vai ouvi-las, e isso só a comunicação pode proporcionar. (UD1-Com1)

\section{$\underline{\text { Embrapa (Sede) }}$}

Por meio das entrevistas, foi possível perceber que existem visões conceituais diferentes acerca da comunicação para transferência de tecnologia nas áreas que atuam corporativamente ligadas a esse processo, ou seja, o Departamento de Transferência de Tecnologia (DTT) e a Secretaria de Comunicação Social (Secom). Todos os entrevistados ligados ao DTT, mesmo com formação em comunicação social, enxergam essa comunicação sob a ótica do desenvolvimento, enquanto na área de comunicação há o entendimento unânime de uma comunicação mais instrumental, que se utiliza de ferramentas e canais de comunicação para dar suporte a um processo.

Não se faz comunicação para a transferência de tecnologia sem comunicação para o desenvolvimento. Não é comunicação instrumental, porque a comunicação instrumental está preocupada com os meios, e a comunicação para o desenvolvimento está preocupada com a mudança social, com que as pessoas sejam realmente sensibilizadas. Aí você tem um alinhamento, um diferencial de conteúdo. Você tem a informação como substrato. (Sede-TT3)

[A comunicação para a transferência] é uma modalidade de comunicação que de alguma forma se utiliza de algumas ferramentas de comunicação, alguns canais e meios de comunicação, para ajudar nesse processo de troca, de intercâmbio de conhecimento [...]. Então a 
comunicação é todo o suporte que a gente pode dar para o processo de transferência.

Acreditamos que, por causa dessa visão conceitual diferente, todos os três entrevistados ligados à área de transferência foram críticos ao modelo de comunicação praticado hoje pelos profissionais de comunicação da Embrapa, de forma geral.

Eu acho que a comunicação da Embrapa precisa aprimorar isso, não é a comunicação para a transferência, é um processo dialógico, que você tem como um instrumental da comunicação, formal, com os seus profissionais com os seus veículos e tudo o mais, [...] mas que você consiga colocar o que é essencial para fugir dessa dimensão do ativo Embrapa. Não é a Embrapa que está colocando o seu ativo para alguém, quer dizer, eи dialoguei com esses atores, eu conheço esses atores, eu interpreto qual a trajetória, e consigo traduzir isso, em diferentes peças, porque eu negociei com as pessoas, eu conversei, eu tive feedback [...]. E ao final desse processo, aqueles conteúdos todos, em que a gente vê significado, e que as pessoas entendem como significantes, porque você conversou antes, realmente cheguem e façam a diferença. Sejam incorporadas de uma forma clara, de uma forma lógica. A Embrapa não sabe fazer isso ou quer experimentar esse fazer com a mesma cabeça do fazer antigo, dessa coisa de uma transferência do seu ativo, de falar que eu tenho um panfleto, dia de campo e uma chamadinha de rádio ou de TV, [então] comuniquei. (Sede-TT2)

Muitas vezes os profissionais de comunicação da Embrapa têm uma visão mais institucional de venda de imagem, venda num bom sentido, no fortalecimento da imagem da Embrapa para os diversos públicos, mesmo na linha de ofertar a tecnologia, mas muitas vezes com um enfoque de reforçar a marca Embrapa, que é importante porque acaba abrindo espaço para outros ambientes, mas que não resolve o problema concreto que é trazer soluções na vida do agricultor, e às vezes tem um descompasso daquilo que é demandado pela área de transferência de tecnologia e o que a comunicação consegue ofertar [...]. (Sede-TT1) 
Essa diferença de entendimento acerca do conceito de comunicação para transferência de tecnologia, bem como o viés de comunicação para o desenvolvimento que vem sendo adotado pelo DTT faz com que a Secom, segundo um dos entrevistados da área de comunicação, evite usar a terminologia "comunicação para a transferência", se eximindo, assim, de possíveis conflitos entre as áreas. Ainda sobre a questão conceitual, o mesmo entrevistado apontou que acha desnecessária a adoção da palavra desenvolvimento para se referir à comunicação para transferência de tecnologia, porque isso é apenas semântica, uma vez que a comunicação social abarca todos os conceitos, e que a comunicação praticada pela Embrapa sempre foi trabalhada de forma estratégica e planejada, buscando o desenvolvimento.

Todos os entrevistados da área de comunicação disseram que hoje existe na estrutura da Secom uma coordenação de negócios, onde fica ancorada a comunicação para a transferência de tecnologia e é ela que dá suporte às ações do DTT. A criação dessa coordenação de negócios foi apontada por um dos entrevistados como um ponto conflituoso entre as áreas, pois seria de interesse do DTT ter uma área de comunicação dentro da sua própria estrutura.

Na teoria e em boa parte da prática, é isso o que acontece. Essa relação de confiança existe, mas também existem entraves. Por que os entraves existem? Porque existe uma competição, porque o DTT, há muito tempo, luta por uma área de comunicação dentro do departamento. (Sede Com1)

Foi apontada por todos os entrevistados a existência de uma relação colaborativa entre o DTT e a Secom em atividades pontuais. Pelas respostas dos entrevistados, percebemos que ainda não existe, ou não foi colocado em prática, um plano estratégico de comunicação para a transferência de tecnologia.

Identificou-se que o DTT conta com o apoio, em diversas ações que têm como foco a discussão ou desenvolvimento de ações de comunicação para a transferência de tecnologia, da Embrapa Informação Tecnológica, uma Unidade de serviço que atua também com comunicação. É nessa Unidade onde são produzidos os programas de TV e rádio da Embrapa. A relação entre o DTT e a Embrapa Informação Tecnológica é apontada pelos três entrevistados da área de transferência de tecnologia como harmônica e colaborativa. 
Segundo alguns entrevistados, o DTT criou documentos norteadores para sua atuação, inclusive com relação à comunicação para a transferência de tecnologia, que estão na Diretoria geral da Embrapa para aprovação. Esses entrevistados acreditam que, quando esses documentos forem institucionalizados, todos os processos serão trabalhados dentro de uma mesma linha de atuação, inclusive a comunicação. Segundo um dos entrevistados, até a relação de colaboração entre as áreas tenderia a funcionar melhor.

Ela [a atuação entre as áreas] tende a funcionar bem, à medida que as pessoas vão compreendendo os conceitos. Quando compreende, todo mundo se engaja, mas acho que estamos caminhando bem. À medida que a gente tiver os documentos institucionais, o Marco Referencial em que nós estamos trabalhando e que está com a Diretoria, à medida que esses documentos forem institucionalizados na empresa, isso vai ficar mais claro. A instituição vai dizer "nós trabalharemos assim”, então assim que uma decisão da diretoria for publicada vai ajudar bastante. (SedeTT1)

\section{$\underline{\text { Embrapa (Unidades) }}$}

Nas Unidades a comunicação para a transferência é realizada pelos Núcleos de Comunicação em parceria com as Áreas de Transferência de Tecnologia, sendo que cada uma planeja as ações de forma particular, de acordo com a linha de atuação adotada pela própria Unidade, visto que, segundo um dos entrevistados, institucionalmente um trabalho mais planejado em termos de diretrizes corporativas ainda está sendo construído.

Não existe uma ação coordenada de comunicação para a transferência na Embrapa nessa linha. Estão começando agora. São coisas pontuais. As Unidades também têm feito trabalhos excelentes de educomunicação, por exemplo, no Nordeste e no Sul. Eu conheço no Nordeste principalmente. Mas são iniciativas de algumas Unidades, porque têm profissionais que trabalham de uma forma muito próxima com a extensão e com algumas associações de agricultores, e que identificaram que essa é uma metodologia muito boa para se trabalhar nessa linha. 
Mas é pontual, não é institucional. Na linha da institucionalidade, ela ainda está em fase de planejamento, estamos começando. (UD1-Com1)

Entre os entrevistados nas Unidades, não foram percebidas discussões ou divergência acerca do conceito de comunicação para a transferência de tecnologia. Todos os profissionais ouvidos, tanto da área de comunicação quanto de transferência parecem ter um entendimento semelhante sobre esse processo.

[A comunicação para a transferência] consiste naqueles processos que nos ajudam a que os agricultores tenham um conhecimento sobre o produto que nós geramos, sejam tecnologias, processos, produtos, mudas, sementes, variedades, manejo de sistemas de produção, todo o processo que facilita que esse conhecimento seja apropriado pelos públicos. (UD2-TT1)

$\mathrm{Na}$ visão de dois entrevistados das Unidades, é necessário adotar uma forma de comunicação mais dirigida quando se faz comunicação para a transferência de tecnologia, ou diferenciada a partir de cada público.

Para mim, seja comunicação para o desenvolvimento ou para a transferência, ela deve trazer esses aspectos que eu acabei de comentar. Ela não pode ser massiva, ela tem que ser dirigida. Mas não dirigida no sentido da persuasão. É uma comunicação em que eu tenho foco, eu não vou falar para um mundo, eu vou falar para um grupo. Se eu vou falar para um grupo, então eu tenho que saber que veículos são mais adequados para eu falar e levar aquela mensagem para aquele público. (UD1-Com1)

Nós, transferência e comunicação, temos que ter olhares diferenciados para pessoas com perfis diferentes. Então essa diversificação de estratégias, formas de comunicar, linguagem, temos que evoluir nessa direção... Não há outra escolha. Um discurso único que vá resolver todos os problemas não funciona. (UD3-TT1) 
Nas Unidades de pesquisa, todos os entrevistados afirmam que não existe nenhum tipo de conflito entre as áreas de comunicação e transferência de tecnologia, e que os trabalhos costumam ser planejados conjuntamente e as ações têm caráter transversal.

Nós temos uma agenda comum num programa de trabalho que se constrói uma agenda para TT, comunicação e inovação, que são as caixinhas que estão vinculadas às chefias de transferência de tecnologia, e ainda que as pessoas estejam às vezes localizadas num setor, ou em outro, a ação é transversal. Quando a gente está numa feira ou exposição, num dia de campo ou num evento, sempre um grupo trabalha junto, de forma coletiva, o que facilita que todos tenham mais ou menos uma linguagem não homogênea, mas uma visão mais próxima possível uns dos outros, para que todos possam falar a mesma língua. (UD2 TT1)

Em uma das Unidades foi apontado por um entrevistado da área de transferência a falta de protagonismo dos profissionais de comunicação para se envolverem no planejamento da comunicação para a transferência, o que impõe à área um trabalho que se limita a atender demandas de outros setores, fato que foi apontado pelo entrevistado da área de comunicação da mesma Unidade.

Nesse caso especificamente da nossa realidade a gente tem percebido que os colegas de comunicação têm evitado assumir certo protagonismo nesse processo, eles têm ficado mais na retaguarda por opção. Não é porque a gente quer dessa forma, foi uma opção dos colegas de comunicação [...], mas se a comunicação não estiver disposta a assumir esse papel ela vai ficar só na dela esperando, a TT vai demandar, $P \& D$ vai demandar, institucional vai demandar e aí vira só prestador de serviço. A comunicação tem que estar lá na frente discutindo junto, participando. (UD3-TT1)

É uma relação boa [entre a área de comunicação e transferência de tecnologia]. É uma relação construtiva, só que ainda tem uma carga 
muito da demanda do núcleo como um fazedor de tarefas e não uma área pensante. (UD3-Com1)

Nas Unidades de pesquisa, os entrevistados disseram que os Núcleos de Comunicação estão vinculados à Chefia de Transferência de Tecnologia, o que contraria uma diretriz corporativa em que a área de comunicação das Unidades deve estar ligada diretamente, como assessoria, à Chefia-Geral da Unidade. No entendimento dos entrevistados dessas Unidades, de ambas as áreas, esse fator favorece a relação entre a transferência de tecnologia e a comunicação.

$\checkmark$ Síntese: A comunicação é considerada fundamental para o processo de transferência de tecnologia, mas na Sede da empresa há sinais de conflito entre as áreas de comunicação e de transferência de tecnologia, a partir da existência de visões conceituais diferentes acerca dessa modalidade de comunicação, que vai da comunicação como apoio às ações de transferência de tecnologia até a comunicação para o desenvolvimento. Não existe um plano estratégico corporativo de comunicação para a transferência de tecnologia, mas há sinalização, por parte da área de transferência, de uma intenção de construí-lo. Já nas Unidades, as ações de comunicação para a transferência são realizadas de acordo com os interesses da própria Unidade, mas os profissionais comungam de visões semelhantes acerca do conceito da comunicação para a transferência e não sinalizam conflitos entre as áreas. 


\section{CONSIDERAÇÕES FINAIS}

Inicialmente, quando acessamos os resultados da pesquisa de imagem realizada pela Embrapa entre 2011 e 2012, nos chamou atenção a indicação, pelos diferentes públicos entrevistados, de que a instituição não estava voltada para a agricultura familiar, deixando a desejar desde a geração de tecnologias, até a comunicação com o segmento. Esse contexto nos pareceu bastante atraente à investigação e foi o que alavancou a construção do projeto de pesquisa. Assim, nos propomos a analisar a política da Embrapa com relação à comunicação aplicada ao processo de transferência de tecnologia para a agricultura familiar, verificando o que é proposto pela instituição e o que os atores, que fazem parte desse processo, pensam e como se manifestam com relação a isso.

Tendo esse objetivo como foco, partimos para a realização de diversas etapas de pesquisa que nos levariam a entender como o processo acontece, estabelecendo, para isso, categorias de análise. Dessa forma, passamos a fazer considerações em relação às observações feitas nas categorias analisadas, que indicam as visões dos atores, que são as seguintes:

\section{Visão dos Agricultores Familiares}

Quanto ao desenvolvimento de tecnologias para a agricultura familiar, a visão é de que:

- Os agricultores familiares, em sua maioria, conhecem as tecnologias geradas pela Embrapa, e uma parcela deles já chegou a usá-las.

Quanto ao conhecimento e percepção acerca da Embrapa, a visão é de que:

- A Embrapa possui uma boa reputação entre os agricultores familiares que enxergam a instituição de uma forma bastante positiva.

Quanto à comunicação e à divulgação da Embrapa, a visão é de que: 
- A comunicação da empresa voltada para os agricultores familiares não está adequada ou não atende as expectativas desses agricultores.

- Existe uma percepção mais positiva no Rio Grande do Sul do que em Goiás em relação à comunicação da Embrapa para a agricultura familiar.

- A Embrapa deveria divulgar mais suas tecnologias.

- Muitos agricultores familiares não têm acesso às tecnologias ou informações sobre elas devido à sua própria falta de interesse.

- Melhorias na comunicação da Embrapa com os agricultores familiares acontecem a partir do estabelecimento de relações pessoais, estabelecidas diretamente com um técnico específico.

Quanto à recepção de informações e conhecimento de veículos de comunicação da Embrapa a visão é de que:

- No Rio Grande do Sul, a Emater é a maior divulgadora das tecnologias da Embrapa, enquanto em Goiás esse papel é desempenhado pela televisão.

- Os programas Dia de Campo na TV e Prosa Rural, sendo o último específico para o público da agricultura familiar, não são conhecidos pelos agricultores familiares.

\section{Visão dos Extensionistas Rurais}

Quanto ao foco e desenvolvimento de tecnologias pela Embrapa para a agricultura familiar, a visão é de que:

- A Embrapa tem como um de seus focos a agricultura familiar e vem desenvolvendo tecnologias para o segmento.

Quanto à comunicação para a transferência de tecnologia para os agricultores familiares, a visão é de que:

- Não é papel da Embrapa fazer comunicação ou divulgação direta para os agricultores, uma vez que a extensão existe para fazer essa "ponte”, fazendo-se necessário um trabalho conjunto entre as duas instituições. 
- Os extensionistas se entendem como parte do processo de transferência de tecnologia, mas sentem dificuldades em entender qual o papel de fato da Embrapa nesse processo, que hoje acaba muitas vezes se imbricando no da própria extensão.

- A Embrapa tenta se comunicar com os agricultores familiares, mas suas ações ainda são inexpressivas ou não são adequadas.

- Existe a necessidade de um trabalho conjunto entre Embrapa e a extensão rural, visto que a extensão tem o papel primordial de ser um agente de desenvolvimento rural, podendo funcionar como um excelente meio de levar as tecnologias da Embrapa até os agricultores familiares.

Quanto à relação estabelecida entre a Embrapa e a extensão rural, a visão é de que:

- A Embrapa é uma empresa parceira com a qual a Emater já mantém uma relação histórica.

- Existe uma desarticulação entre a Embrapa e a Emater, sendo a visão mais expressiva entre os extensionistas goianos.

- A Embrapa se coloca como protagonista quando da realização de ações conjuntas com a extensão rural.

- A relação da Embrapa com a Emater não se desenvolve plenamente em âmbitos institucionais como deveria ser e as boas relações existentes estão ligadas as pessoas que fazem parte de ambas as instituições e que interagem entre si.

- As relações e as visões pessoais dos profissionais da Embrapa e da Emater também interferem de modo negativo, até mesmo em âmbito político gerencial, impactando fortemente na relação entre as duas instituições.

- A relação entre Embrapa e Emater é pautada por demanda, em que normalmente os contatos são estabelecidos a partir de ações específicas ou em situações pontuais.

Quanto à comunicação da Embrapa com a extensão rural, a visão é de que:

- Os extensionistas gaúchos têm uma visão mais favorável com relação à comunicação da Embrapa com a extensão. 
- Em Goiás são percebidos entraves na comunicação entre a Embrapa e a extensão rural e que essa não acontece de forma planejada e nem em fluxo contínuo.

- Existe, de forma geral, a percepção de que comunicação também parece ser construída a partir de ações pontuais e, sobretudo, pessoais.

\section{Visão Embrapa (Empregados/Gestores)}

Quanto ao foco e desenvolvimento de tecnologias para a agricultura familiar, a visão é de que:

- A instituição está voltada para a agricultura familiar e desenvolve tecnologias para o segmento.

- Atualmente a agricultura familiar é vista como de grande importância para o país e alvo de diversas políticas públicas. E essa situação produz reflexos diretamente na Embrapa, empresa pública alinhada com as políticas governamentais.

- A maior dificuldade é fazer com que qualquer inovação chegue aos agricultores familiares, tanto por conta de um modelo inadequado de transferência de tecnologia, quanto pelo sensível enfraquecimento da extensão rural no país.

Quanto à comunicação para a transferência de tecnologia para os agricultores familiares, segundo os empregados da Embrapa, a visão é de que:

- Inexiste um planejamento corporativo para atender esse público especificamente. Nas Unidades as ações costumam acontecer de forma minimamente planejada entre as áreas de comunicação e transferência de tecnologia, mas de forma randômica.

- O programa de rádio Prosa Rural é uma ação pontual de comunicação da Embrapa voltada especificamente para o público da agricultura familiar, mas há uma indicação de que esse não estaria adequado para atender as diferenças regionais da agricultura familiar.

- Existe a necessidade de uma comunicação diferenciada para atender ao segmento de agricultores familiares. 
Quanto à relação estabelecida entre a Embrapa e a extensão rural, a visão é de que:

- A Embrapa tem muito a avançar com relação à extensão rural, e hoje, encontrase um pouco distante dos órgãos responsáveis pela sua execução no país.

- A Embrapa, quando realiza ações em parceria com alguma instituição de extensão rural, coloca-se como protagonista.

- A relação precisa ser reestruturada entre a Embrapa e a extensão rural, tendo como base uma estrutura mais dialógica, diferente do modelo que vem sendo praticado.

- A existência em determinados estados de uma extensão rural fortalecida proporciona uma relação mais promissora entre Embrapa e a Ater local.

- A relação da Embrapa com a extensão rural não é institucionalizada pela empresa como um todo e as relações são construídas de forma particular pelas Unidades.

- Mudanças positivas na relação da Embrapa com a extensão rural acontecerão a partir da criação da Agência Nacional de Assistência Técnica e Extensão Rural (Anater).

Quanto à comunicação da Embrapa com a extensão, a visão é de que:

- Não existem estratégias de atuação institucionalizadas ou formais, mas sim algumas ações pontuais e cotidianas.

Quanto à transferência de tecnologia como papel da Embrapa, a visão é de que:

- A Embrapa tem como papel fazer a transferência, uma vez que esta, junto com a geração da tecnologia, faz parte do processo de inovação.

- Mesmo sendo papel da instituição fazer a transferência da tecnologia por ela gerada, essa não tem que acontecer diretamente para o usuário final, sendo a extensão rural o intermediário nesse processo. 
Quanto à importância atribuída pela Embrapa à transferência de tecnologia, a visão é de que:

- Existe a necessidade de ela ocupar um papel estratégico dentro da instituição, como também de ser tão valorizada quanto a área de pesquisa.

- A área vem sendo fortalecida dentro da Embrapa, mas ainda há pouco resultado desse processo refletindo externamente, ou seja: junto ao público a quem se destinam as ações de transferência de tecnologia.

Quanto à comunicação para a transferência de tecnologia no cenário da Embrapa, a visão é de que:

- A comunicação é essencial para o processo de transferência de tecnologia.

- Não existe, ou não foi colocado em prática, um plano estratégico de comunicação para a transferência de tecnologia na Embrapa.

- Existem entendimentos conceituais diferentes acerca da comunicação para transferência de tecnologia, como também conflitos, nas áreas corporativas que atuam nesse processo.

- É necessário adotar uma forma de comunicação mais dirigida quando se faz comunicação para a transferência de tecnologia, ou diferenciada a partir de cada público.

- Nas Unidades a comunicação para a transferência é realizada pelos Núcleos de Comunicação em parceria com as Áreas de Transferência de Tecnologia, sendo que cada Unidade planeja as ações de forma particular, de acordo com a linha de atuação adotada pela própria Unidade.

- Nas Unidades de pesquisa não há conflito aparente entre as áreas de comunicação e transferência de tecnologia, e os trabalhos costumam ser planejados conjuntamente com ações de caráter transversal.

A partir das visões dos atores, podemos fazer algumas considerações acerca do fenômeno estudado, conforme segue: 
Todos os atores envolvidos no processo identificam claramente que a Embrapa também tem como foco a agricultura familiar e desenvolve tecnologias para o segmento, o que faz com que seja esperado que a instituição estabeleça, de forma efetiva, uma comunicação com esse público, que hoje é prioritário na esfera governamental.

A Embrapa possui uma boa reputação entre os agricultores familiares que enxergam a instituição de uma forma bastante positiva. Acreditamos que isso se deve, além do trabalho de pesquisa, a um trabalho de comunicação que vem sendo realizado pela instituição desde meados da década de 1990. Quando falamos dessa comunicação, nos referimos especificamente à comunicação institucional, àquela que, segundo consta no documento Política de Comunicação da Embrapa, é "responsável por dar visibilidade à gestão administrativa e a filosofia negocial, à competência técnica e científica da Embrapa" e que possibilitou a construção de uma imagem sólida e assertiva da instituição.

É percebido tanto pelos agricultores, quanto pelos extensionistas rurais, movimentos da Embrapa para estabelecer uma comunicação com os agricultores familiares, mas ambos os atores apontam que a comunicação é escassa, fragmentada ou inadequada. Creditamos essa percepção, como também os entraves na comunicação com o segmento, à inexistência de um planejamento de comunicação estratégico direcionado especificamente para a agricultura familiar, conforme sinalizado pelos gestores corporativos entrevistados, que apontaram a realização apenas de ações pontuais, que nem sempre são conhecidas pelo público em questão, como é o caso do programa de rádio Prosa Rural, que tem como foco os agricultores familiares, mas é desconhecido por eles.

Encontramos uma grande diferença entre os agricultores familiares gaúchos e os goianos na forma de se relacionar com a Embrapa, muito pautada em uma relação mediada pela Emater de cada estado e suas circunstâncias. No Rio Grande do Sul, foram encontrados agricultores que possuem uma proximidade com a extensão local que acaba figurando como um elo entre a Embrapa e os agricultores familiares, como também uma grande divulgadora das tecnologias da instituição. Já em Goiás, sem uma relação articulada com a extensão, os agricultores familiares não chegam a estabelecer nenhum tipo de relação com a Embrapa, e tomam conhecimento das suas pesquisas e tecnologias por meio da TV. Assim, entendemos que a relação desarticulada da Embrapa com a extensão rural como um todo, bem como a fragilidade encontrada nas empresas públicas 
de extensão, reflete sensivelmente na comunicação com os agricultores familiares, uma vez que são essas empresas que costumam intermediar a relação da instituição com o segmento. Os agricultores familiares deixam claro que existem problemas, que a comunicação da Embrapa não funciona bem e que quando funciona tem a presença do extensionista. Isso nos permite afirmar que qualquer política adotada quanto à comunicação para a transferência para o segmento, necessariamente, precisa considerar também a relação com a extensão rural, como também a comunicação que será adotada para com ela.

Particularmente, quanto à relação estabelecida entre a Embrapa e a Emater, há um reconhecimento da parceria histórica, tanto pelos extensionistas, quanto pelos empregados da Embrapa, mas também é apontada a falta de articulação entre as instituições. Identificamos que para ambos os atores existe a percepção de um protagonismo assumido pela Embrapa quando da realização de ações conjuntas, o que acaba causando um descontentamento na extensão rural, criando barreiras na relação. Para os extensionistas, a Embrapa ainda está distante da extensão e não utiliza todos os recursos oferecidos pela parceria entre as instituições. Reconhecidamente, a relação entre a Embrapa e a extensão rural é pautada pelas relações pessoais, que podem facilitar ou dificultar o trabalho conjunto, refletindo diretamente na ponta do processo, ou seja: na agricultura familiar.

Mas como tornar essa parceria mais institucionalizada? Qual seria o primeiro caminho a ser seguido pela Embrapa? Percebemos que há uma grande expectativa na instituição de que a Anater seja a solução para esse problema, mas não teria meios de a própria instituição se articular para estabelecer uma relação mais próxima com a extensão rural a partir de direcionamentos ou ações materializadas nesse sentido? Talvez seja necessário à Embrapa conhecer mais esse parceiro, abrir espaços de diálogo e criar mecanismos de retroalimentação, que possam dar subsídios para o estabelecimento de estratégias relacionais institucionalizadas. Também é importante que a instituição reveja essa postura de "protagonista" na realização de projetos conjuntos, para que a parceria seja de fato vista como um espaço de compartilhamento e cooperação mútua.

Internamente, identificamos que existe uma grande valorização da comunicação institucional, que é bastante articulada e tem o papel de projetar e manter a marca pública e social da Embrapa. Essa é entendida como estratégica para a instituição, em detrimento da comunicação para a transferência de tecnologia, que acontece sem muito 
planejamento, muitas vezes por omissão dos profissionais da área de comunicação, que não têm preparação para pensá-la, ou porque não querem competir por espaço em um terreno onde claramente se dá uma disputa de poder dentro da empresa. Nesse cenário, acreditamos que talvez seja uma saída para a Embrapa valorizar mais a comunicação voltada para a transferência de tecnologia e preparar os profissionais de comunicação para atuarem nessa área. É também imprescindível que a empresa comece a pensar a comunicação para a transferência de tecnologia de forma estratégica, porque não é compreensível que uma instituição que tem uma imagem sólida e uma trajetória de comunicação amplamente reconhecida e forte não consiga estabelecer uma comunicação assertiva e articulada com um público tão específico e próximo, como o da agricultura familiar.

Assim, diante do que encontramos em documentos institucionais, no campo, nas críticas dos atores e nas configurações das relações, é possível afirmar que não existe na Embrapa uma política de comunicação articulada no que se refere à transferência de tecnologia para a agricultura familiar, bem como não há um consenso institucional do processo, dos conceitos e das possibilidades de ação com o segmento. Percebemos que existem movimentos no sentido de estabelecer uma política que tenha como foco a comunicação para a transferência de tecnologia para a agricultura familiar, mas isso ainda é bastante idealizado, não apresentando nenhum tipo de materialização. Inclusive, fazemos questionamentos acerca do estabelecimento de diretrizes comunicacionais e de relacionamento com um determinado público, sem a participação efetiva da área de comunicação da instituição.

Ainda consideramos que a política adotada pela Embrapa com relação à comunicação para a transferência de tecnologia, como um todo, não é clara. A comunicação para a transferência de tecnologia aparece no documento Política de Comunicação da Embrapa, ancorada na comunicação mercadológica, como também na estrutura da Secretaria de Comunicação da instituição, mas na prática pouco se vê em projetos e ações.

A partir das configurações apresentadas, entendemos que o problema não pode ser simplesmente atribuído à Embrapa, sem levar em consideração o contexto do sistema de pesquisa e desenvolvimento de tecnologia, que historicamente é centrado na geração e não na transferência, a atual fragilidade da extensão rural pública no país, como também o cenário interno construído a partir de diferentes crenças e posicionamentos, mas, sobretudo, entendemos que cabe à Embrapa começar a discutir internamente 
possibilidades de enfrentar o que se coloca ao seu alcance, tais como uma forma de minimizar as disputas internas, uma proposta de alinhamento conceitual acerca da comunicação para a transferência de tecnologia, como ainda uma nova configuração do espaço de atuação entre as áreas envolvidas nesse processo, possibilitando, talvez, que assim seja estabelecida uma política articulada que permita que a empresa avance no sentido de desenvolver novas formas de usar a comunicação para a transferência de tecnologia.

Diante disso, acreditamos que os dados aqui levantados podem contribuir para essa reflexão interna na instituição, ajudando a pensar em caminhos a serem seguidos e decisões a serem tomadas.

Por fim, entendemos ainda que cabe à Embrapa, empresa pública subordinada às políticas governamentais, democratizar o acesso às informações técnico-científicas, socializar os conhecimentos gerados pela empresa e estabelecer uma relação que possa contribuir no fortalecimento da agricultura familiar e em sua inserção no processo de desenvolvimento. 


\section{REFERÊNCIAS}

BARDIN, Laurence. Análise de Conteúdo. Lisboa: Edições 70, 1977.

BARRANQUERO, Alejandro. Concepto, instrumentos y desafíos de la educomunicación para el cambio social. Comunicar, Huelva, España, año/vol. XV, n. 29, p. 115-120, 2007.

BELTRÁN, Luis Ramiro. Comunicacion para el Desarrollo en Latinoamerica: Una evaluación sucinta al cabo de cuarenta años. IV Mesa Redonda sobre Comunicación y Desarrollo organizada por el Instituto para América Latina (IPAL) en Lima, Perú, entre el 23 y el 26 de febrero de 1993. Disponível em: < http://www.infoamerica.org/teoria_articulos/beltran1.htm> Acesso em: 08 dez. 2013.

BELTRÁN, Luis Ramiro. La comunicacion para el desarrollo en latinoamerica: un recuento de medio siglo. In: CONGRESO PANAMERICANO DE LA COMUNICACION, 3., Buenos Aires, 2005, Buenos Aires. Anais eletrônicos ... Buenos Aires: Universidad de Buenos Aires, 2005. Disponível em: <http://www.infoamerica.org/teoria_textos/lrb_com_desarrollo.pdf $>$. Acesso em: 06 dez. 2013

BELTRÁN, Luis Ramiro. El pensamiento latinoamericano sobre comunicación democrática. In: Tendencias'2007 - Medios de Comunicación: El Escenario Iberoamericano. Colección Fundación Telefónica, 2007. p. 275-289. Disponível em: http://www.infoamerica.org/primera/anuario_medios.pdf . Acesso em: 08 dez. 2013.

BELTRAO, Selma Lúcia. Desafios da comunicação da Embrapa para um diálogo interinstitucional no Território do Sisal (BA): continuidades e rupturas com o modelo difusionista. Intercom, 2009, disponível em < http://www.intercom.org.br/papers/nacionais/2009/resumos/R4-0865-1.pdf > acesso em: 09 nov. 2013.

BOBBIO, Norberto; MATTEUCUCCI, Nicola; PASQUINO, Gianfranco. Dicionário de Política. Brasília: Editora da UnB, 1998.

BRASIL. Lei $\mathrm{n}^{\mathrm{o}} 11.326$, de 24 de julho de 2006. Disponível em: < http://www.planalto.gov.br/ccivil_03/_ato2004-2006/2006/lei/111326.htm> acesso em 09 nov. 2013.

CALlOU, Ângelo. Brás F.; TAUK SANTOS, Maria Salett. Políticas públicas e associativismo agrícola no nordeste do Brasil. Revista da Rede universitária das Américas em estudos cooperativos e associativismo vol.6 n.1 outubro de 2008 Sherbrooke, CA: Universidade de Sherbrooke, p.33-47.

CALLOU, Ângelo Brás F.; TAUK SANTOS, Maria Salett. Estratégias governamentais de comunicação para o associativismo e desenvolvimento local. In: TAUK SANTOS, Maria Salett, CALLOU Angelo Brás Fernandes (Orgs.) Associativismo e Desenvolvimento Local Recife: Bagaço, 2006. 
CHRISTENSEN, Carl; ROCHA, Angela. Marketing e Transferência de Tecnologia. In ROCHA, Angela (org.) Marketing de Tecnologia: textos e casos. São Paulo; Rio de Janeiro: Editora da UFRJ, 1989.

DEMO, Pedro. Metodologia em Ciências Sociais. 3.ed. rev. e ampl. São Paulo: Atlas, 1995.

DINIZ, Célia Regina; SILVA, Iolanda Barbosa. Metodologia científica. Campina Grande; Natal: UEPB/UFRN - EDUEP, 2008.

DUARTE, Jorge. Comunicação e Tecnologia na Cadeia Produtiva da Soja no MT. Tese (Doutorado) - Universidade Metodista de São Paulo, Curso de Pós-Graduação em Comunicação Social, São Bernardo do Campo, 2004.

DUARTE, Jorge e; BARROS, Antonio (org.). Métodos e Técnicas de Pesquisa em Comunicação. São Paulo: Atlas, 2011.

DUARTE, Jorge. Entrevista em Profundidade. In DUARTE, Jorge e; BARROS, Antonio (org.). Métodos e Técnicas de Pesquisa em Comunicação. São Paulo: Atlas, 2011.

EMBRAPA. Política de Comunicação, Brasília, 1996.

EMBRAPA. Política de Comunicação, Brasília, 2002.

EMBRAPA. Plano Diretor da Embrapa 2008-2023, Brasília, 2008.

EMBRAPA.. Missão $\quad$ e $\quad$ Atuação, disponível em <http://www.embrapa.br/a_embrapa/missao_e_atuacao $>$. Acesso em: 06 nov.2013

EMBRAPA. Marco Referencial de Transferência de Tecnologia, Intercâmbio e Construção Coletiva do Conhecimento - Fundamentos sobre a interação entre a Embrapa e a Sociedade, Brasília: DTT, 2014.

EMBRAPA. Embrapa em Números / Embrapa, Secretaria de Comunicação. Brasília, DF: Embrapa, 2015.

ESTEVA, Gustavo. Desenvolvimento. In: Dicionário do Desenvolvimento: Guia para o conhecimento como poder. SACHS, Wolfgan (Editor). Petrópolis: Editora Vozes, 2000 .

FAO/ONU. Comunicación y desarrollo sostenible: selección de artículos de la 9na mesa redonda de lãs Naciones Unidas sobre comunicación para el desarollo. Roma. FAO/ONU. 2007. 147 p. Disponível em: <http://www.fao.org/docrep/010/a1476s/a1476s00.htm>. Acesso em: 8 dez. 2013

FAO/ONU. Comunicación para el desarrollo. Disponível em < http://www.fao.org/communication-for-development/es/>. Acesso em 02 fev. 2015. 
FRANÇA, Fábio. Públicos: Como identifica-los em uma nova visão estratégica. São Caetano do Sul: Yendis Editora, 2004.

FRANÇA, Caio. et al. O censo agropecuário 2006 e a agricultura familiar no Brasil. Brasília: MDA, 2009.

FREITAS, Henrique Mello Rodrigues de; Janissek, Raquel. Análise léxica e análise de conteúdo: técnicas complementares, sequenciais e recorrentes para exploração de dados qualitativos. Porto Alegre: Sagra Luzzatto, 2000.

FREIRE, Paulo. Extensão ou Comunicação? Rio de Janeiro: Editora Paz e Terra, 1971.

FUCK, Marcos Paulo. Funções Públicas e arranjos institucionais: o papel da Embrapa na organização da pesquisa de soja e milho híbrido no Brasil. Campinas: Departamento de Política Científica e Tecnológica (DPCT/IG/Unicamp). Dissertação de Mestrado, 2005.

FUCK, Marcos Paulo; et al. P\&D de interesse público? Observações a partir do estudo da Embrapa e da Petrobras. Engevista, v. 9, p. 85-99, 2007.

FURTADO. Celso. Pequena Introdução ao Desenvolvimento. São Paulo: Companhia Editora Nacional, 1980.

FURTADO. Celso. Os desafios da nova geração. Revista de Economia Política. v. 24, n. 4, p. 483-486, out.-dez. 2004. Disponível em: <http://www.rep.org.br/pdf/96-1.pdf>. Acesso em: 28 nov. 2013.

GASQUES, José Garcia; VIEIRA FILHO, José Eustáquio Ribeiro e; NAVARRO, Zander (orgs.). A Agricultura Brasileira: desempenho, desafios e perspectivas. Brasília: IPEA, 2010.

GIBBONS, Michael. The New Production Of Knowledge; The Dynamics of Science and Research in Contemporary Societies. London: SAGE Publications, 1994.

GIL, Antonio Carlos. Métodos e Técnicas de Pesquisa Social. São Paulo: Atlas, 2012.

GUANZIROLI. Carlos; et al. RESR. Piracicaba-SP, Vol. 50, No 2, p. 351-370, Abr/Jun 2012 - Impressa em maio de 2012.

HEBERLÊ, Antônio; SOARES, Felipe. Comunicação para o desenvolvimento: estratégias e conceitos. Pelotas: UFPEL, 2013.

IBGE. Censo Agropecuário 2006. Agricultura Familiar. Primeiros resultados. Brasil, Grandes Regiões e Unidades da Federação. Rio de Janeiro, 2009.

JANUZZI, Celeste Aída. Informação Tecnológica para Negócios no Brasil: Conceitos e Terminologias. Campinas: Alínea, 2002. 
KAGEYAMA, Angela A. Desenvolvimento Rural - Conceitos e Aplicação ao Caso Brasileiro. Porto Alegre: Editora da URGS, 2008.

LANDAU, Elena Charlote. et al. Variação geográfica do tamanho dos módulos fiscais no Brasil. Sete Lagoas: Embrapa Milho e Sorgo, 2012.

LAVILLE, Christian; DIONNE, Jean. A Construção do Saber: manual de metodologia da pesquisa em ciências humanas. Porto Alegre: Artmed; Belo Horizonte: Editora UFMG, 1999.

MAAR, Wolfgang Leo. O que é Política. São Paulo: Editora Brasiliense, 2006.

MARQUES, Paulo Eduardo Moruzzi; SILVEIRA, Miguel Ângelo ; CÓRDOVA, Thais Gabriele Zamboni. Um balanço da pesquisa sobre a agricultura familiar no Brasil: o caso da Embrapa. VII Congreso Latino-Americano de Sociología Rural 20-24 de noviembre del 2006 - Quito, Ecuador. Disponível em <www.economia.esalq.usp.br/intranet/uploadfiles/2277.doc > acesso em: 09 nov. 2013.

MATTELART, Armand e Michèle. História das Teorias da Comunicação. 14. Ed. São Paulo: Edições Loyola, 2011.

META INSTITUTO DE PESQUISA. Relatório Final da Pesquisa de Imagem Embrapa 2011, Porto Alegre, 2012, 121p.

MDA/INCRA/FAO. Cardim, S. (INCRA) e Guanziroli, C. (FAO) (coord.). Novo Retrato da Agricultura Familiar: O Brasil Redescoberto. Brasília: Ministério do Desenvolvimento Agrário/Instituto Nacional de Colonização e Reforma Agrária, 2000.

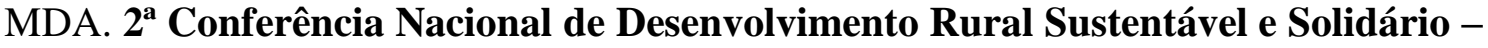
Documento de Referência. Brasília: MDA, 2013.

MOLINA, Luiz Fernando de Freitas. A comunicação como Elemento Estratégico da Agricultura Familiar. Dissertação (mestrado) - Universidade de Brasília, Faculdade de Comunicação, Programa de Pós-Graduação. Brasília, 2004.

MOREIRA, Sonia Virgínia. Análise documental como método e como técnica. In DUARTE, Jorge e; BARROS, Antonio (org.). Métodos e Técnicas de Pesquisa em Comunicação. São Paulo: Atlas, 2011.

NAVARRO, Zander. A Agricultura Familiar no Brasil: entre a política e as transformações da vida econômica. In GASQUES, José Garcia; VIEIRA FILHO, José Eustáquio Ribeiro e; NAVARRO, Zander (orgs.). A Agricultura Brasileira: desempenho, desafios e perspectivas. Brasília: IPEA, 2010.

PARADA, Eugenio Lahera. Política y Políticas Públicas. In: SARAVIA, Enrique; FERRAREZI, Elisabete. (orgs.). Políticas públicas; coletânea V. 1. Brasília: ENAP, 2007. 
PEIXOTO, Marcus. Extensão Rural no Brasil - Uma Abordagem Histórica da Legislação. Textos para Discussão 48. Brasília, 2008. Disponível em: < http://www.senado.gov.br/conleg/textos_discussao.htm>. Acesso em: 20 set. 2014.

PNUD BRASIL. Relatório de Desenvolvimento Humano, 2009-2010: Brasil ponto a ponto - consulta pública, Brasília: PNUD, 2009. 72 p. Disponível em: $<$ http://www.pnud.org.br/HDR/Relatorios-Desenvolvimento-Humanobrasil.aspx?indiceAccordion=2\&li=li_RDHBrasil >. Acesso em: 09. dez. 2013.

PONCHIO, Ana Paula Silva. Comunicação e Desenvolvimento de Agricultores Familiares de Teodoro Sampaio-SP. Tese (Doutorado) - Unicamp. Campinas, 2011.

RAMALHO, José P.; CONTINI, Elísio. Considerações Teóricas sobre o mercado de tecnologias agropecuárias. In: YEGANIANTZ, Levon (Org.) Pesquisa Agropecuária: questionamentos, consolidação perspectivas. Brasília: Embrapa, 1988.

SACHS, Ignacy. Desenvolvimento: includente, sustentável, sustentado. Rio de Janeiro: Garamond, 2008.

SALLES-FILHO, S. (coord.) et al. Ciência, tecnologia e inovação - a reorganização da pesquisa pública no Brasil. Campinas: Editora Komedi, 2000.

SANTOS, Luzmair de Siqueira. Manual de Eventos. Brasília: Embrapa, 2006.

SARAVIA, Enrique. As Empresas Estatais como Instrumento da Política CientíficoTecnológica. Cadernos EBAPE.BR - Edição Especial. FGV, 2005.

SARAVIA, Enrique. Introdução à teoria da política pública. In: SARAVIA, Enrique; FERRAREZI, Elisabete. (orgs.). Políticas públicas; coletânea V. 1. Brasília: ENAP, 2007.

SCHNEIDER, Sergio. Agricultura familiar e desenvolvimento rural endógeno: elementos teóricos e um estudo de caso. In: Froehlich, J.M.; Vivien Diesel. (Org.). Desenvolvimento Rural - Tendências e debates comtemporâneos. Ijuí: Unijuí, 2006.

SCHNEIDER, Sergio. Reflexões sobre diversidade e diversificação - agricultura, formas familiares e desenvolvimento rural. RURIS - Revista do Centro de Estudos Rurais - Unicamp. v. 4, n. 1. Campinas: Unicamp. 2010.

SEN, Amartya Kumar. Desenvolvimento como Liberdade. São Paulo: Companhia das Letras, 2000.

SERVAES, J. MALIKHAO, P. Comunicaciõn Participativa: el nuevo paradigma. In: Thorton, R. D. Cimadevilla, G. (Org.) Usos y abusos del participar. Buenos Aires: Ediciones INTA, 2010.

SILVA, Heloiza Dias. DUARTE, Jorge A. M. Política de Comunicação e gestão empresarial: a experiência da Embrapa. In: XXX Intercom. Santos, 2007. [Anais...]. CDROM. 
TAUK SANTOS. Maria Salett. Políticas Públicas de Comunicação para Desenvolvimento no Contexto Rural Brasileiro do Século XXI. In: XXXV Intercom. Fortaleza, 2012.

THE COMMUNICATIONS INITIATIVE; FOOD AND AGRICULTURES ORGANIZATION OF THE UNITED NATIONS; THE WORLD BANK. World Congress on Communication for Development - Lessons, Challenges, and the Way Forward, 1, 2007, Roma: The Communications Initiative; FAO/ONU; World Bank, 2007.

TRIVIÑOS, Augusto Nibaldo Silva. Introdução à Pesquisa em Ciências Sociais. São Paulo: Atlas, 1990.

VAlEnte, Ana Lúcia E. F. Algumas Reflexões sobre a Polêmica Agronegócio Versus Agricultura Familiar. Brasília: Embrapa Informação Tecnológica, 2008.

VEIGA, José Eli. Desenvolvimento sustentável: o desafio do século XXI. $3^{\text {a }}$ ed. Rio de Janeiro: Garamond, 2008.

VILLANUEVA, Luis F. Aguilar. Estudio introductorio. In: SARAVIA, Enrique; FERRAREZI, Elisabete. (orgs.). Políticas públicas; coletânea V. 1. Brasília: ENAP, 2007.

WANDERLEY, Maria de Nazareth Baudel. Olhares sobre o "rural" brasileiro. Raízes, Campina Grande, vol. 23, ns 01 e 02, p. 82-98, jan./dez. 2004. 


\section{APÊNDICE A}

\section{ROTEIRO DE ENTREVISTA AGRICULTORES FAMILIARES}

\section{PERFIL}

Idade:

Escolaridade

Tempo de serviço na agricultura

Tamanho da propriedade

Familiares envolvidos no trabalho agrícola

Tipo de cultura

De forma geral, como costuma se informar (jornal/revistas/televisão/internet)?

Com relação a tecnologias agrícolas, como obtém informação?

\section{CONHECIMENTO ACERCA DA EMBRAPA}

1) O que conhece da Embrapa? O que acha que a Embrapa faz?

2) O que pensa sobre a Embrapa? Qual a primeira coisa que vem a sua cabeça?

\section{TECNOLOGIAS GERADAS}

3) As tecnologias geradas pela Embrapa são importantes para o desenvolvimento da agricultura no país?

4) Conhece alguma tecnologia gerada pela Embrapa? Qual? Como conheceu?

5) Já usou tecnologia gerada pela Embrapa? Qual? Como teve acesso?

6) A Embrapa desenvolve tecnologias para a agricultura familiar?

\section{COMUNICAÇÃO PARA TT}

7) Costuma receber informações sobre a Embrapa, suas pesquisas, tecnologias e produtos?

8) De que forma?

9) Entende o que é dito? Existe algum tipo de dificuldade? Facilidade?

10) Conhece o programa de rádio da Embrapa Prosa Rural e/ou o programa de TV Dia de Campo na TV?

11) Já buscou informações junto à Embrapa? Sobre? Como foi atendido? 
12) Já participou de cursos/palestras/dias de campo promovidos pela Embrapa ou em parceria? O que achou?

13) Recebe algum tipo de assistência técnica?

14) Alguém da assistência técnica já indicou alguma tecnologia/informação gerada pela Embrapa?

15) O que acha da divulgação das tecnologias geradas pela Embrapa?

16) O que pensa sobre a comunicação da Embrapa com os agricultores familiares? Sugestões? 


\section{APÊNDICE B}

\section{ROTEIRO DE ENTREVISTA \\ EXTENSIONISTAS}

\section{1- PERFIL}

Idade

Escolaridade

Tempo de serviço na Emater/Extensão Rural:

\section{2 - PERCEPÇÃO EMBRAPA}

1) O que pensa sobre a Embrapa?

2) Conhece as tecnologias geradas pela Embrapa?

3) As tecnologias geradas pela Embrapa são importantes para o desenvolvimento da agricultura brasileira?

4) Há quem diga que o papel da Embrapa é fazer pesquisa e não transferência de tecnologia. Como isso é visto por você?

\section{3 - RELAÇÃO/ COMUNICAÇÃO EXTENSÃO COM A EXTENSÃO}

5) Como vê a relação da Embrapa com a Extensão Rural, de forma geral?

6) Como vê a relação da Embrapa com a Emater local?

7) E a comunicação da Embrapa com a empresa? O que é bom e o que precisa mudar?

8) Qual o papel oficial da Extensão Rural no processo de Transferência de Tecnologia? Qual papel você acha que ela deveria desempenhar? O que falta para acontecer desta maneira?

\section{2- RELAÇÃO/ COMUNICAÇÃO EMBRAPA E AGRICULTURA}

\section{FAMILIAR}

10) Como vê a relação entre Embrapa e agricultura familiar? Por quê? O que é positivo e o que está faltando?

11) Como vê a comunicação da Embrapa com esse segmento?

EXTRA: Para você, qual será o impacto da criação da Agência Nacional de Assistência Técnica e Extensão Rural (Anater) na Embrapa e na ATER? O que muda? Como avalia? 


\section{APÊNDICE C}

\section{ROTEIRO DE ENTREVISTA \\ EMBRAPA SEDE}

1) Há quem diga que o papel da Embrapa é fazer pesquisa e não transferência de tecnologia. Como isso é visto por você?

2) Hoje, qual o papel e a importância da transferência de tecnologia na Embrapa?

3) Como vê a relação da Embrapa com a ATER?

4) Qual o papel da ATER no processo de Transferência de Tecnologia?

5) Qual o impacto da criação da Agência Nacional de Assistência Técnica e Extensão Rural (Anater) na Embrapa e na área de transferência de tecnologia?

6) Como vê a relação entre Embrapa e agricultura familiar?

7) Qual a importância desse público para a Embrapa?

8) Como os agricultores familiares tem acesso as tecnologias geradas pela Embrapa?

9) Como vê a comunicação da Embrapa com os Agricultores Familiares? E com relação à transferência de tecnologia para este seguimento?

10) $\mathrm{Na}$ última pesquisa de imagem realizada pela Embrapa foi apontado que a Empresa não se comunica de forma adequada com os agricultores familiares. O que acha sobre isso?

11) O que entende por comunicação para a transferência de tecnologia?

12) Qual o papel e a importância da comunicação para o processo de transferência de tecnologia realizado pela Embrapa?

13) Com relação à Comunicação para transferência de tecnologia voltada para a Agricultura Familiar, existe alguma ação ou estratégia de comunicação diferenciada? 
14) Essa comunicação é realizada de forma planejada?

15) Se sim, como é feito esse planejamento? Conta com a participação de profissionais de comunicação?

16) Quais as principais ações e estratégias de comunicação adotadas pela Embrapa para a transferência de tecnologia para a agricultura familiar?

17) Qual a relação do Departamento de TT com a Secom? Existe colaboração no planejamento e/ou execução de estratégias e ações de comunicação entre os setores? Dê que forma isso acontece? (Adequar a pergunta para a relação para cada entrevistado de acordo com o seu setor de trabalho). Funciona bem?

18) Pode-se dizer que as áreas trabalham de forma colaborativa e coordenada? Dá forma como acontece, dá certo?

19) Existe algum tipo de conflito entre as áreas? Se sim, por quê?

20) Qual seria a forma ideal de fazer comunicação para transferência de tecnologia no que se refere à agricultura familiar? 


\section{APÊNDICE D}

\section{ROTEIRO DE ENTREVISTA \\ EMBRAPA UNIDADES}

1) Há quem diga que o papel da Embrapa é fazer pesquisa e não transferência de tecnologia. Como isso é visto por você?

2) Hoje, qual o papel e a importância da transferência de tecnologia na Embrapa?

3) Como vê a relação da Embrapa com a Extensão Rural?

4) Qual o papel oficial da Extensão Rural no processo de Transferência de Tecnologia? Qual papel você acha que ela deveria desempenhar? O que falta para acontecer desta maneira?

5) Qual o impacto da criação da Agência Nacional de Assistência Técnica e Extensão Rural (Anater) na Embrapa e na área de transferência de tecnologia? O que muda? Como avalia?

6) Como vê a relação entre Embrapa e agricultura familiar? Por quê? O que é positivo e o que está faltando?

7) Qual a importância desse público para a Embrapa?

8) Como os agricultores familiares tem acesso as tecnologias geradas pela Embrapa?

9) Como vê a comunicação da Embrapa com os Agricultores Familiares? E com relação ao uso da comunicação para à transferência de tecnologia para este seguimento?

10) O que entende por comunicação para a transferência de tecnologia?

11) Vê diferença de entendimento sobre esse conceito entre profissionais da área de comunicação e de TT? 
12) Qual o papel e a importância da comunicação para o processo de transferência de tecnologia realizado pela Embrapa?

13)Com relação à Comunicação para transferência de tecnologia voltada para a Agricultura Familiar, existe alguma ação ou estratégia de comunicação diferenciada? Teoria e prática.

14) Quais as principais ações e estratégias de comunicação adotadas pela Embrapa, de forma corporativa, para a transferência de tecnologia para a agricultura familiar?

15) Na unidade, a comunicação para a transferência de tecnologia é realizada de forma planejada?

16) Se sim, como é feito esse planejamento? Conta com a participação de profissionais de comunicação? Como é a relação dos profissionais envolvidos?

17)Qual a relação da área de Transferência com o Núcleo de Comunicação? Existe colaboração no planejamento e/ou execução de estratégias e ações de comunicação entre os setores? Dê que forma isso acontece? Funciona bem? Por quê?

18) Pode-se dizer que as áreas trabalham de forma colaborativa e coordenada? Dá forma como acontece, dá certo?

19) Existe algum tipo de conflito entre as áreas? Se sim, por quê?

20) De que maneira você idealiza uma atuação razoável entre as áreas?

21) $\mathrm{Na}$ última pesquisa de imagem realizada pela Embrapa foi apontado que a Empresa não se comunica de forma adequada com os agricultores familiares. $\mathrm{O}$ que acha sobre isso? Concorda? Por quê? 
